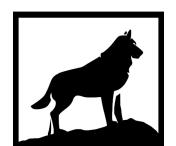

Michigan Technological

1 8 8 5 University
Michigan Technological University Digital Commons @ Michigan Tech

ETHNOBOTANY, ECONOMICS, AND CULTURAL SIGNIFICANCE OF TRADITIONAL HAT MAKING IN TWO DISTRICTS OF CENTRAL PANAMA

Sam Clair

Michigan Technological University, sjclair@mtu.edu

Recommended Citation

Clair, Sam, "ETHNOBOTANY, ECONOMICS, AND CULTURAL SIGNIFICANCE OF TRADITIONAL HAT MAKING IN TWO DISTRICTS OF CENTRAL PANAMA", Open Access Master's Thesis, Michigan Technological University, 2016.

https://doi.org/10.37099/mtu.dc.etdr/232 


\title{
ETHNOBOTANY, ECONOMICS, AND CULTURAL SIGNIFICANCE OF TRADITIONAL HAT MAKING IN TWO DISTRICTS OF CENTRAL PANAMA
}

By

Samuel J. Clair

\begin{abstract}
A THESIS
Submitted in partial fulfillment of the requirements for the degree of

MASTER OF SCIENCE

In Forestry
\end{abstract}

MICHIGAN TECHNOLOGICAL UNIVERSITY

2016

(C) 2016 Samuel J. Clair 
This thesis has been approved in partial fulfillment of the requirements for the Degree of MASTER OF SCIENCE in Forestry.

School of Forest Resources and Environmental Science

Thesis Advisor: $\quad$ Dr. Molly Cavaleri

Committee Member: $\quad$ Dr. Blair Orr

Committee Member: Dr. Audrey Mayer

School Dean: Dr. Terry Sharik 


\section{TABLE OF CONTENTS}

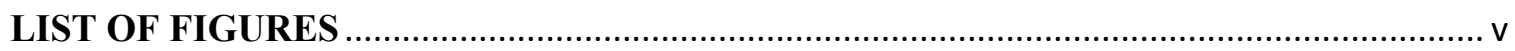

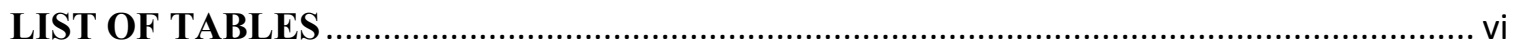

ACKNOWLEDGEMENTS …................................................................................. vii

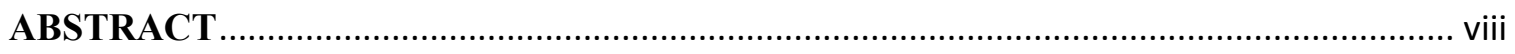

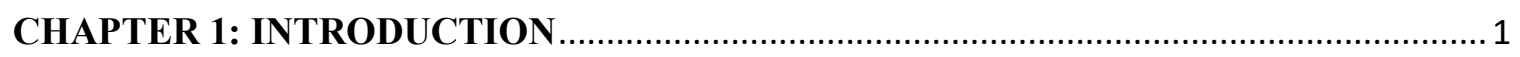

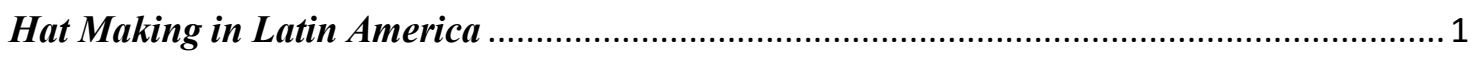

Plant Accessibility and Economics of Hat Making ............................................................. 3

CHAPTER 2: BACKGROUND, OBJECTIVES, AND STUDY QUESTIONS ..................... 5

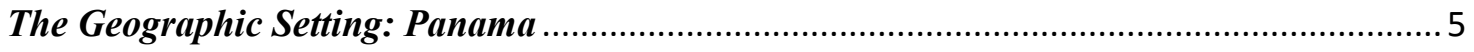

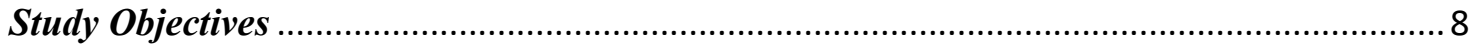

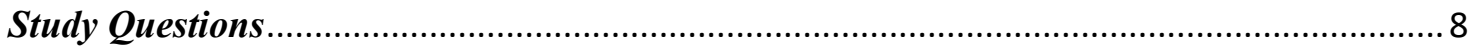

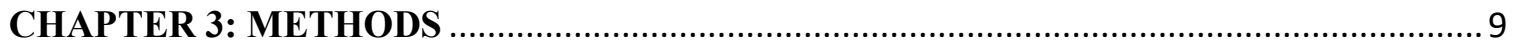

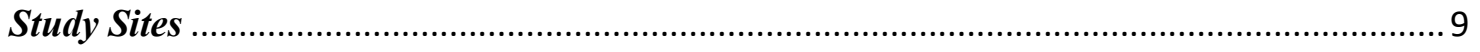

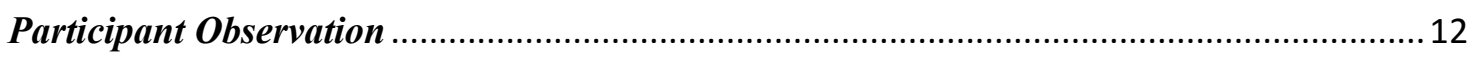

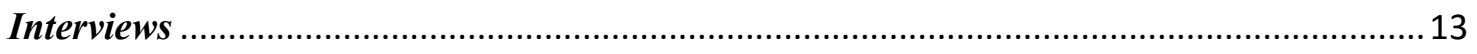

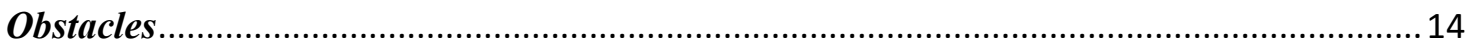

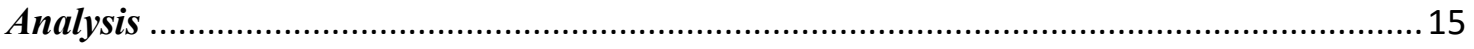

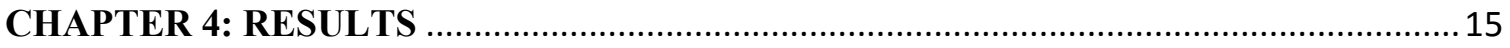

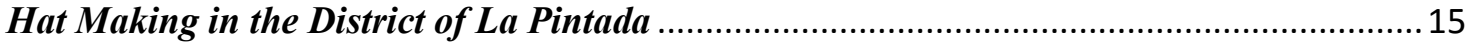

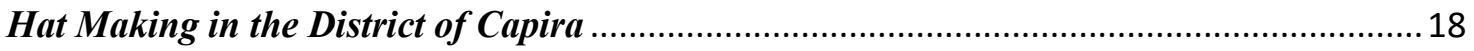

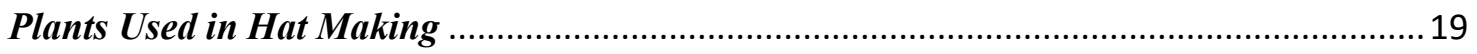

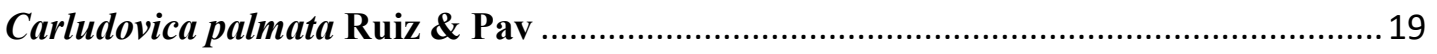

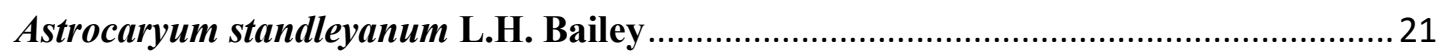

Furcraea cabuya Trel. and Aechmea magdalenae André ex Baker .............................. 23

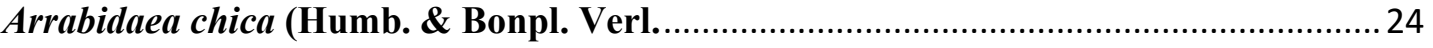

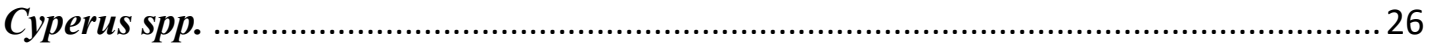

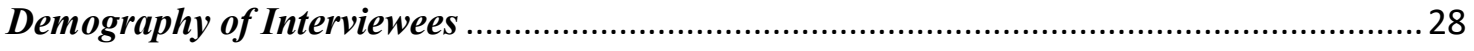

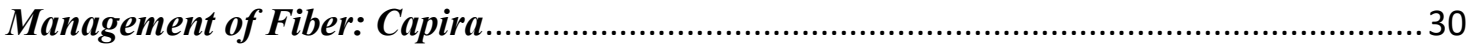




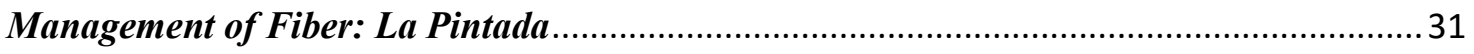

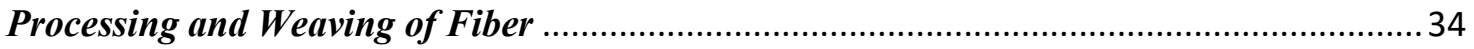

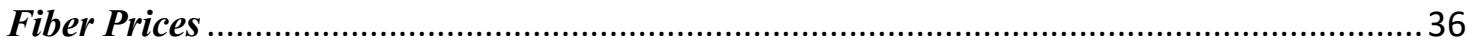

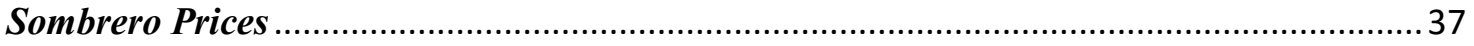

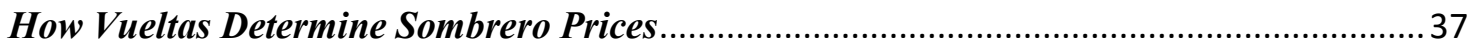

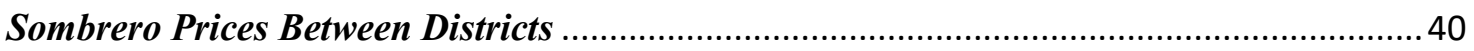

Intermediary Prices Compared to Direct Prices ............................................................... 45

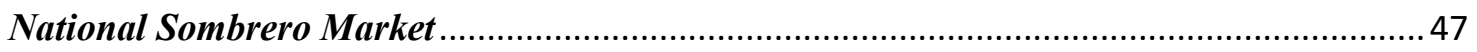

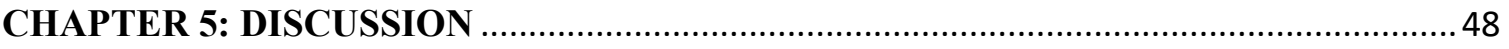

The Availability of Fiber in Relation to the Hat Market ….................................................... 48

Improved Management of Fiber and Its Benefits to Weavers and Processors...................... 50

Variation in fiber and sombrero pricing by time, district, gender, age, and buyer ................ 52

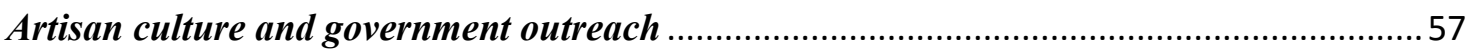

CHAPTER 6: CONCLUSIONS AND RECOMMENDATIONS ...........................................61

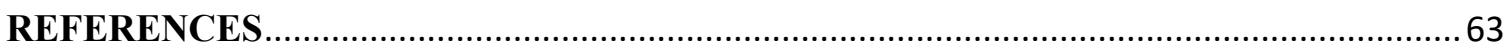

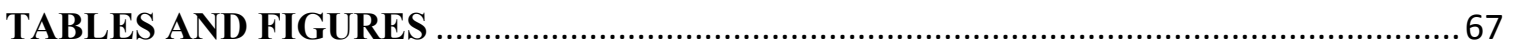

APPENDIX A

Documentation that Figure 1 map is in the public domain ................................................ 79

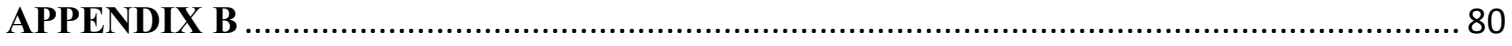

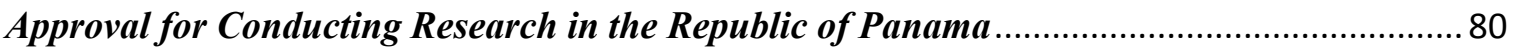

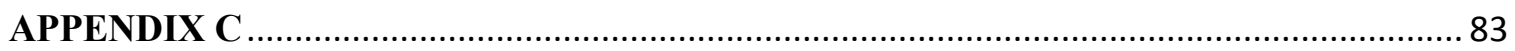

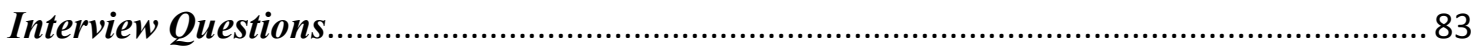




\section{LIST OF FIGURES}

Figure 1. Location of Panama in Central America and the Provinces of Panama. ........................ 7

Figure 2. Road leading into Las Claras Arriba, Capira.......................................................... 10

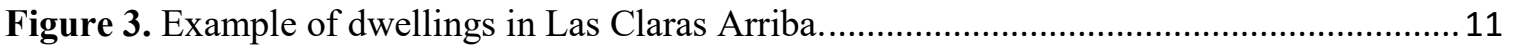

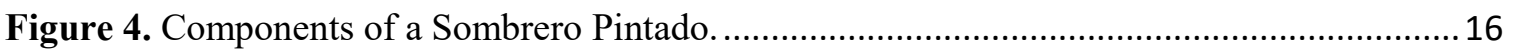

Figure 5. Braided C. palmata that is used for vueltas. ......................................................... 17

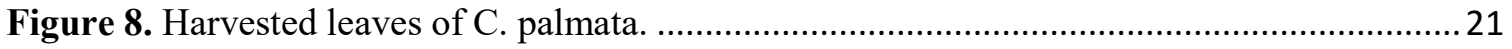

Figure 7. Fiber processor in La Pintada standing with his plantings of C. palmata....................... 21

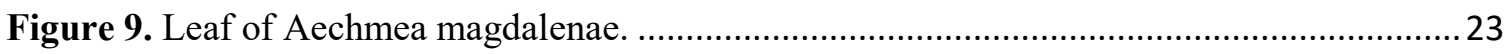

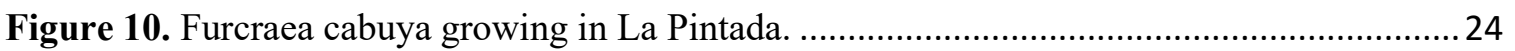

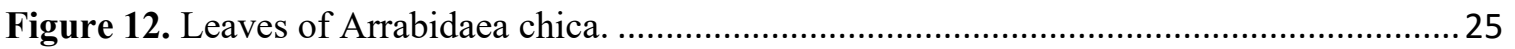

Figure 11. Mortar and pestle used for threshing rice or crushing .......................................... 25

Figure 13. Cyperus spp. growing in La Pintada.................................................................. 26

Figure 14. Age classes and gender of weavers interviewed for this study from La Pintada (A) and

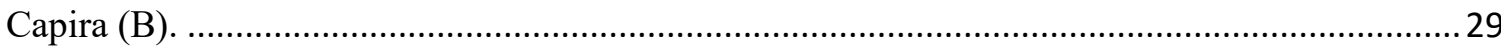

Figure 15. C. palmata seedlings (left image) and seeds (right image)...................................... 32

Figure 16. The traditional motete used for carrying harvests from the field, or in this case, small

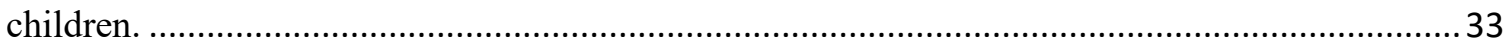

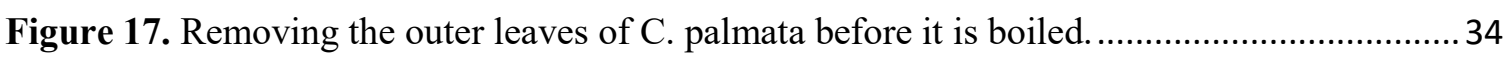

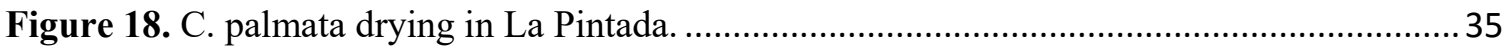

Figure 19. Average price per processed leaf of C. palmata in La Pintada and Capira..................37

Figure 20. Ordinary Sombrero Pintado with seven vueltas. .................................................. 38

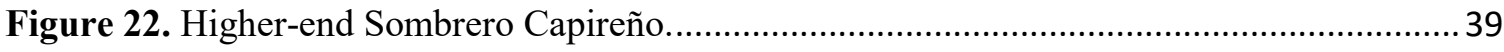

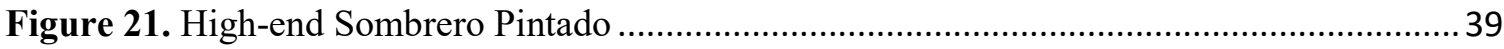

Figure 23. Typical Sombrero Capireño sells for around $\$ 80$. Photo by Sam Clair....................... 40

Figure 24. Average sombrero prices between Capira and La Pintada...................................... 41

Figure 25. Average Price of Sombreros for Male and Female Weavers in La Pintada (A) and

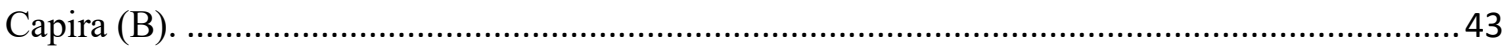

Figure 26. Average Price of Sombreros by Age Class for La Pintada (A) and Capira (B)..........44

Figure 27. Price Paid by Consumers and by a Sombrero Finisher at Atlapa Convention Center,

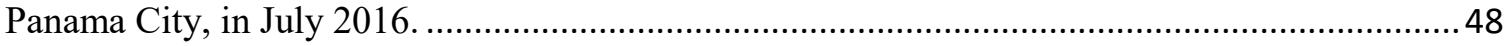

Figure 28. Proof of Payment for Scientific Permit from Ministry of Environment..................... 78

Figure 29. Scientific Permit from Ministry of Environment.................................................... 78

Figure 30. Approval from Peace Corps Country Director to Conduct Research While Serving in

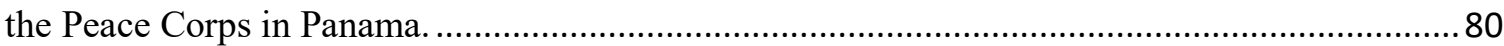




\section{LIST OF TABLES}

Table 1. Plants Used in Making a Sombrero Pintado

Table 2. Comparing Earnings per Hour for Male Weavers from Capira to Female Weavers of La

Pintada.

Table 3. Potential Earnings from a Five Vuelta Sombrero Compared to an Eight Vuelta .............57

Sombrero in La Pintada.

Table 4. Estimated Monthly Income of Three Classes of Weavers in Capira District, Panama

Oeste, Panama.

Table 5. Estimated Monthly Income of Two Classes of Weavers in La Pintada District, Coclé, Panama. 59

Table 6. Pricing of Somberos by Artisan Group in Las Delicias, La Pintada, Coclé, Panama..... 56

Table 7. Average number of $C$. palmata leaves harvested each month by fiber processors in the district of La Pintada, Coclé, Panama.

Table 8. Price Per Processed Leaf of C. palmata in the District of Capira ...................................68

Table 9. Price Per Processed Leaf of C. palmata in the District of La Pintada............................69

Table 10. Sombrero Prices in the Community of La Bonga Abajo, Capira, Panama. .................. 70

Table 11. Consumer Prices of Sombrero Pintados at Atlapa Convention Center, Panama City,

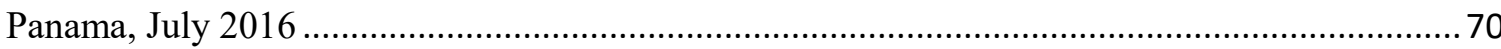

Table 12. Price Paid for Sombreros by a Sombrero Finisher. July 2016 ..................................72

Table 13. Sombrero Prices from 2007 and from ten years before 2007(Fernandez 2007). .........73

Table 14. Average Sombrero Prices for the District of La Pintada, Coclé, Panama. 2016..........73

Table 15. Average Sombrero Prices within the District of Capira, Panama Oeste. 2016 .............74 


\section{ACKNOWLEDGEMENTS}

Special thanks go to my parents, John and Carol Clair, for giving me their support during graduate school and Peace Corps. Without Kyle Fredrickson I might not have had the courage to enter the PCMI program at Michigan Tech, and if not for Tim Filipa I might not have joined the Peace Corps. Otto Wiegand of Spooner taught me that there is a big world to see. Thanks to him I am no longer pulling weeds for a living.

To all the people of Las Claras Arriba, Panama, who made my two years abroad a memorable time. You can all come harvest cucumbers at my farm anytime you like. And to everyone in the Peace Corps office, thanks for keeping me alive for two years.

To all my friends and forester alliances at Michigan Tech, you have made this a fantastic place to return to. Thank you to my advisor, Molly Cavaleri, for all the advice during this project. Thank you to Blair Orr for the good humor and insight. All those stories about Peace Corps kept me smiling through the hard times. Thank you to Audrey Mayer for being on my committee and for all the assistance while I was in the field. 


\begin{abstract}
Panamanian sombreros are made from a palm-like tropical grass called Carludovica palmata. In Panama, there are two distinct styles of sombreros: Pintado and Capireño. While several other plants are used in the traditional Pintado, the Capireño is made entirely from the dried fiber of C. palmata. Both sombrero styles are woven by rural people, who are for the most part subsistence farmers. Formal employment is scarce in rural Panama, and so are incomes for rural inhabitants. Sombrero weaving is one small industry that can earn money for both men and women.
\end{abstract}

The purpose of this study was to document the plants used in sombrero production, and to determine if individual weavers were limited by access to the plant fiber. Next, I sought to determine if improved management of fiber would be beneficial to those involved in the sombrero industry. Infrastructure, artisan culture, and government outreach were compared between two sombrero-producing districts in Panama in relation to the sombrero market. Finally, sombrero prices by weaver gender and age were compared between two districts, and current sombrero prices were compared to prices from ten years ago.

My results suggested that individual weavers in Panama may lack access to fiber. For this reason, improved management of plants could provide individuals with additional fiber that could be used to improve earnings from hat sales. Government outreach has been assisting artisans in the district of La Pintada, but additional help that focuses on irrigation would be beneficial. Education for weavers and support of weaving groups may prove beneficial also, especially in terms of supporting work done by female weavers. 


\section{CHAPTER 1: INTRODUCTION}

This project began during my service in Panama from 2014-2016 through the Peace Corps Master's International program. I was sent to a rural Latino community to help improve agricultural practices through fish farming and soil conservation. In addition to my duties as a Peace Corps volunteer, I selected a topic to study for my MS Forestry thesis. I chose to study traditional hat making for several reasons. First, hats are seen everywhere throughout rural Panama. They are generally worn by men, but women may be seen with them also. Second, it interested me that there was a cottage industry in rural Panama that could connect weavers to the economic market. Last, I wanted to learn and document the plants that are utilized in hat weaving. Since there is little written about hats outside of Panama, my goal was to share this culture with the outside world.

Chapter one examines hat making throughout Latin America, focusing on Ecuador and Mexico. This chapter discusses plants used in hat confection, and the economics of this industry in countries outside Panama. Chapter two explains the geography of Panama, introduces government ministries that work to help rural people, and lists study questions for this project. Chapter three explains the methods used in my research. This chapter explains the study sites that were used, as well as explains how interviews were conducted. This chapter discusses obstacles that were encountered while in the field, and how data were analyzed. Chapter four shows my results. This includes information on the differences in weaving between both districts, plants that were utilized in weaving, differences in prices for fiber and sombreros between districts, how plants were managed, and comparisons of income generated between age and gender. Chapter five follows with a discussion of these topics, and Chapter six list conclusions and recommendations based on the results and discussion.

\section{Hat Making in Latin America}

Hat making in Panama takes place in the houses of rural people. Hats are worn by inhabitants from the interior, and hat style often can signify the origin of the wearer. The 
Sombrero Pintado is a distinct style of hat that is made in the District of La Pintada, in the province of Coclé. The Sombrero Capireño is a different style, common to the District of Capira, in the Panama Oeste province. Hats in Panama are significant culturally, since they are worn for folkloric celebrations, but they are used also in the daily attire for many men. Apart from being culturally important, hats provide an economic livelihood for those who weave and sell.

Hats have a long history in Latin America. For example, the famous Panama hats from Ecuador were used exclusively by members of the elite and were highly valued as an exotic item in Europe during the sixteenth and seventeenth centuries of the colonial period (Gallegos and Burbano 2004). By 1810, Panama hats were one of the main products exported in brigs to Spain from Ecuador (Gallegos and Burbano 2004) and in 1862 Carludovica palmata Ruiz \& Pav was second in importance only to cacao as an export product from Ecuador (Gallegos and Burbano 2004).

Although the Panama hat originated in Ecuador, it does have a connection to Panama. These hats were so named because they were shipped to Panama and were made fashionable by miners heading west for the 1849 gold rush in California. These same hats continued their popularity through the building of the Panama Canal from 1870 -1911 (Fadiman 2001). The use of hats was popularized further by the revolutionary fighters in the Cuban war of independence, and by soldiers in the Spanish-American war (Fadiman 2001).

Mexico has an interesting sombrero culture as well. Weavers in Mexico have been making hats with C. palmata since this plant was introduced in Becal, Campeche in 1866 (Fadiman 2001). Fadiman (2001) writes that hat-weaving probably originated in Mexico with the Spaniards in 1519, since the Yucatec Maya did not have this custom. The Maya did weave sleeping and sitting mats, however, from the unopened palm fronds of Sabal mexicana Mart. During the colonial period Spaniards sought protection from the sun and asked indigenous people to modify their mat-making practice to accommodate hats (Fadiman 2001). As of the early 2000s, people in the region no longer made mats, and 
during the past fifty years hat weaving has evolved into a major local industry (Fadiman 2001).

Sombreros in Panama are worn almost exclusively by men, but women may be seen wearing them on occasion. Since men do not wear suits in rural Panama, the sombrero is one item a man can wear for a formal event. There is a cultural significance to how a sombrero is worn, although this is open to interpretation. When both brims are down, the hat wearer is said to be at odds with someone. When the front brim is worn upright, the wearer is said to be looking for a fight. When only the back brim is up, it means the wearer is looking for a woman. When both brims are worn upright, this is called a la pedra, and it implies that one is successful and is comfortable with his current life.

\section{Plant Accessibility and Economics of Hat Making}

Carludovica palmata is known as the 'Panama hat palm' in English, as 'paja toquilla' in Spanish, and as 'bellota' in many parts of Panama. Small pottery and stone figures dating from $\mathrm{AD} 500$ to $\mathrm{AD} 1500$ reveal that $C$. palmata was already used for making cloth in pre-Columbian times in Ecuador (Gallegos and Burbano 2004). While this plant is best known for its use in the Panama hat (Gallegos and Burbano 2004), it is also used for basketry (Runk 2001), roof thatching (Bennett 1992), and brooms (Bristol 1961, Bennett 1992, Fadiman 2001).

In Ecuador, Mexico, and Panama the leaves of C. palmata are processed for hat making using a process that softens and whitens the fibers (Fadiman 2001, Gallegos and Burbano 2004, Chízmar 2009). The veins are separated and the immature leaf is boiled, washed with cold water, and placed in the sun until it turns white in color. C. palmata can be harvested continually from the same plant, and collection does not necessarily kill the plant (Bennett 1992). Little has been written, however, about the overall plant management practices, harvesting practices, or sustainability of C. palmata or other plants used in hat making in Central Panama. 
Ecuador has a history of being much more involved with international hat sales than Panama. In the early 1970s, Ecuador was creating four million hats annually (Purseglove 1972), and in the late 1980s more than one million hats were exported each year from Ecuador (Mabberley 1987). In 2013, it is reported that Ecuador exported six million dollars in hats (Economist 2014). The approximate number of people involved with processing and weaving hats in Ecuador in 1996 was 40,000 (Gallegos and Burbano 2004), while there are only 181 registered sombrero artisans in the Province of Coclé, as of 2013 (Lasso 2013).

Although little is known of the hat market in Panama, weavers in Mexico and Ecuador typically receive only a fraction of the retail selling price of sombreros (Fadiman 2001, Gallegos and Burbano 2004). Weavers in Ecuador receive less for their work than do intermediaries (Gallegos and Burbano 2004), with weavers in Mexico experiencing the same issue (Fadiman 2001). Prices of Panamanian sombreros can vary greatly. Crudelymade sombreros sell for as little as four dollars, while higher-end sombreros sell for $\$ 300$ and up to $\$ 1,000$ (Chízmar 2009). In general, the communities that are financially dependent on the sale of plant fiber and hats have never received the full distribution of this income (Gallegos and Burbano 2004, Russell 2010)

The intent of this study was to examine the state of sombrero production in Panama, specifically within the two districts of Capira, Panama Oeste, and La Pintada, Coclé. The district of La Pintada, Cocle is said to be the best place for sombreros in Panama. I lived in Panama for two years as a Peace Corps volunteer, and this study was done through observation and semi-formal interviews. I talked to hat weavers around the community where I was living and in the neighboring province. I wanted to discover if the best hats truly came from La Pintada, and if this was the case, whether weavers in La Pintada received an economic advantage over weavers in Capira. Furthermore, I wished to determine if there were any threats that could endanger the production of sombreros and thus hamper the livelihood of those involved with the industry. Finally, I aimed to develop recommendations to improve and sustain the sombrero industry in Panama. 


\section{CHAPTER 2: BACKGROUND, OBJECTIVES, AND STUDY QUESTIONS}

\section{The Geographic Setting: Panama}

The Republic of Panama is a thin strip of land that connects North and South America. Panama is the lowest and narrowest portion of the Central American isthmus, at slightly over 29,000 square miles in size (Weil 1972). The highest elevations are found in the west near Costa Rica and in the east near Colombia, and the continental divide runs through the center of the country at the lowest elevations where the Panama Canal is located (Weil 1972).

Spanish is the official language and is spoken by nearly all Panamanians (Weil 1972). English is a popular second language and is used by the Antillean community (of British West Indies ancestry) and by many North Americans living in the Canal Zone (Weil 1972). English continues to be a popular language among better-educated Panamanians, and many people in Panama City speak and understand English. Several indigenous languages are used by native peoples, especially those living in the Comarcas, which are semi-autonomous provinces where indigenous people live. The more popular of these are the dialects of the Ngäbe-Buglé people who live in the highlands around Chiriquí and Bocas del Toro, and the dialects of the Embera-Wounaan people who live in the Darién province of Panama.

Climate in Panama is tropical with high temperatures and high humidity year round, and cooler temperatures in the western highlands and on the Pacific side of the continental divide. Seasons are not determined by changes of temperature, but instead by the amount of rainfall. Winter is a long rainy season between May and December, and summer is a short dry season between December and April (Meditz and Hanratty 1989).

Panamanians have a life expectancy of 77 years and a mean annual income of $\$ 12,000$ (Bank 2016). In spite of these optimistic figures, large populations of Panamanians live in 
city slums, Comarcas, and rural communities. These areas lack many basic services, including roads, health clinics, proper public schools, sanitation, water systems, and electricity.

The Ministry of Agriculture (Ministerio de Desarrollo Agropecuario, or MIDA) works with both small and large-scale farmers to improve production, for example, through the use of fertilizers, soil conservation, improved seeds, free tools, and education from agriculture technicians. Another federal agency, the Ministry of Environment (Ministerio de Ambiente, or Mi Ambiente) works with communities to keep natural resources protected. Projects include recycling programs, composting toilets, and ecological stoves that require less wood for cooking food. There is also a strong reforestation program in this ministry that is working to preserve soil and watersheds, especially around the canal. 


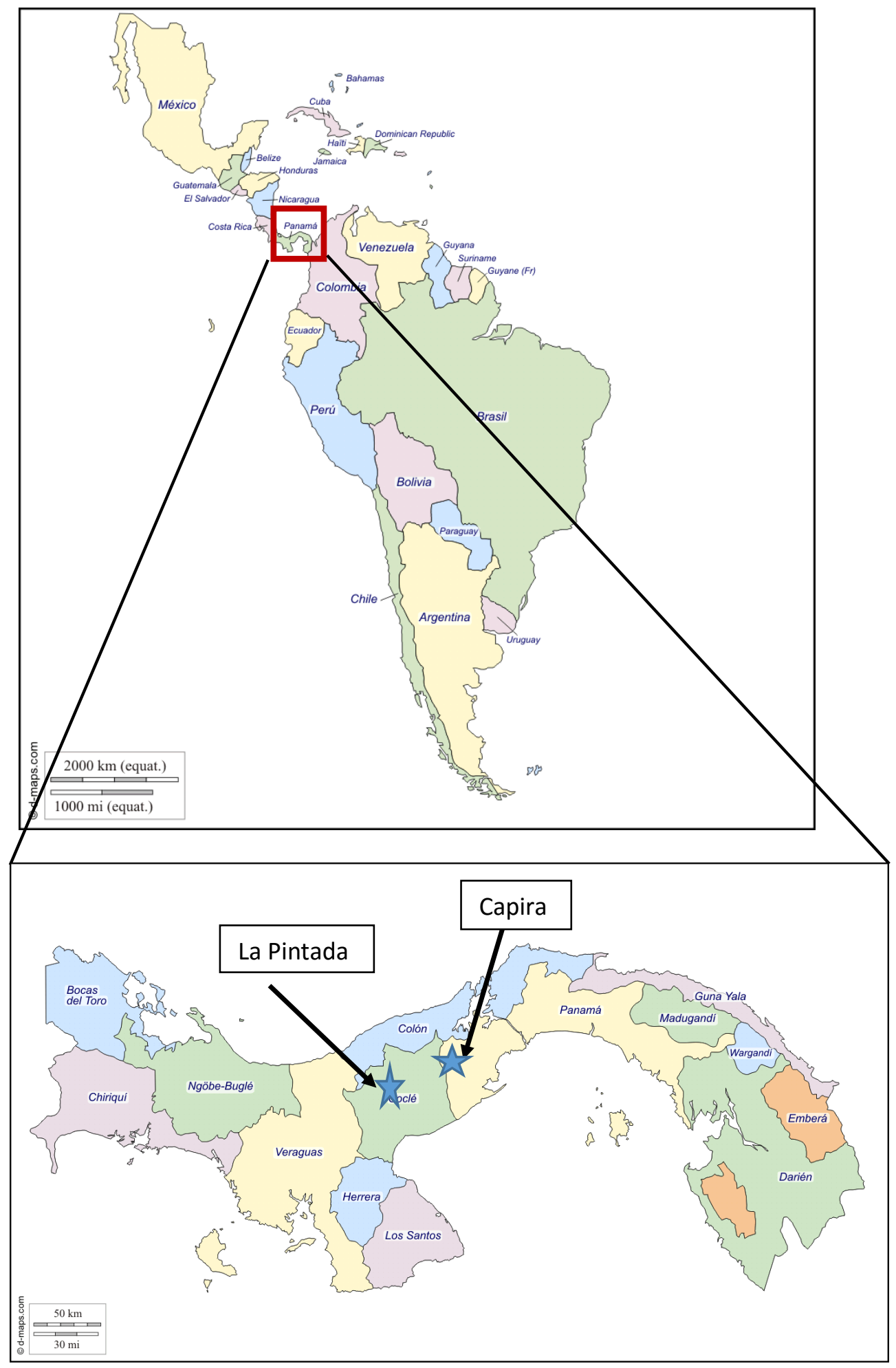

Figure 1. Location of Panama in Central America and the Provinces of Panama. Source: D-map.com (Dalet 2016). See Appendix A for documentation that this material is in the public domain. 


\section{Study Objectives}

The overall objective of this study was to examine how sombrero weaving affected the lives of Panamanians. Since sombreros are made from plants that are typically found in the wild, this study aimed to discover how these plants were being managed, and if plants ran any risks from over-extraction. Next, this study intended to examine the economics of fiber processing and sombrero weaving, and how this household industry contributed to the livelihoods of rural families. Last, this study intended to make recommendations on plant management and marketing of sombreros that could help improve current conditions for artisans involved in the sombrero industry.

\section{Study Questions}

1. Is the growth of the sombrero market in either La Pintada or Capira limited by the availability of either $C$. palmata (i.e., bellota) or A. standleyanum (i.e., chonta)?

2. How does infrastructure, artisan culture, and government outreach compare between La Pintada and Capira? How do these factors contribute to different economic returns on sombreros for each district?

3. How do fiber prices or sombrero prices differ by district? How do sombrero prices differ by age class or gender of the weaver? How do prices differ between direct versus intermediary sales? Have sombrero prices increased over the last ten years? If so, why might this be? 


\section{CHAPTER 3: METHODS}

\section{Study Sites}

\section{District of Capira: Communities of Las Claras Arriba and La Bonga Abajo}

The community of Las Claras Arriba is in the district of Capira, within the province of Panama Oeste (Figure 1). Approximately 64 households and 364 persons live in Las Claras Arriba. The climate is hot and humid, with a dry season each year from January to April. The area is considered lowlands at $200 \mathrm{~m}$.a.s.1 with an average temperature of $26.6^{\circ} \mathrm{C}$ and annual rainfall of $1972 \mathrm{~mm}$ (Meditz and Hanratty 1989) The wettest part of the year is October through December, while the dry season is from January until April.

Most community members in Las Claras Arriba own large tracts of land, or have access to land through family ties. The ability to practice successful agriculture, however, is limited by poor soils, rugged terrain, no forms of mechanized planting or tilling, high variability in seed viability, and unpredictable rainfall. Many families use slash and burn agricultural practices each summer to prepare a small parcel for rice, yuca, corn, or some other staple crop. Several families grow coffee for personal consumption but very few sell. Coffee was once a large cash-crop here, but is no longer a large part of farms because very little coffee was ever replanted, and soils have deteriorated to a point where coffee will not grow in most places. To add to this, a beetle called the broca (Hypothenemus hampei) arrived in recent years to destroy what little coffee had remained.

Apart from raising crops, a few families with more resources have cattle, and nearly every family has chickens. A few have pigs, and one farmer keeps goats. Livelihood is mainly subsistence with some additional income from school scholarships. A government-run social security program, known as Red de Oportunidades (opportunity net), pays $\$ 100$ per month to families living in extreme poverty. This is a new program designed to help alleviate poverty in Panama (Social 2016). People over age 65 receive a check for $\$ 120$ each month, which serves as a form of social security. Day-labor, when it 
is available in the community, offers ten dollars per day plus lunch. A few people work tending cattle for large ranches in the area. Very few people work outside the community, but there is a nearby pineapple farm which provides free transportation to and from the work site one hour each way, paying twelve dollars per day.

Las Claras Arriba received a gravel road in 2014 (Figure 2), which connects the community to an asphalt road about two kilometers away in the community of El Harino. From El Harino, vehicles are about a 30-minute drive away from the Inter-American Highway. Since there are no roads that lead further into the interior around Las Claras Arriba, community members who live in the hills around the community must travel by foot on dirt paths to reach their homes and farms.

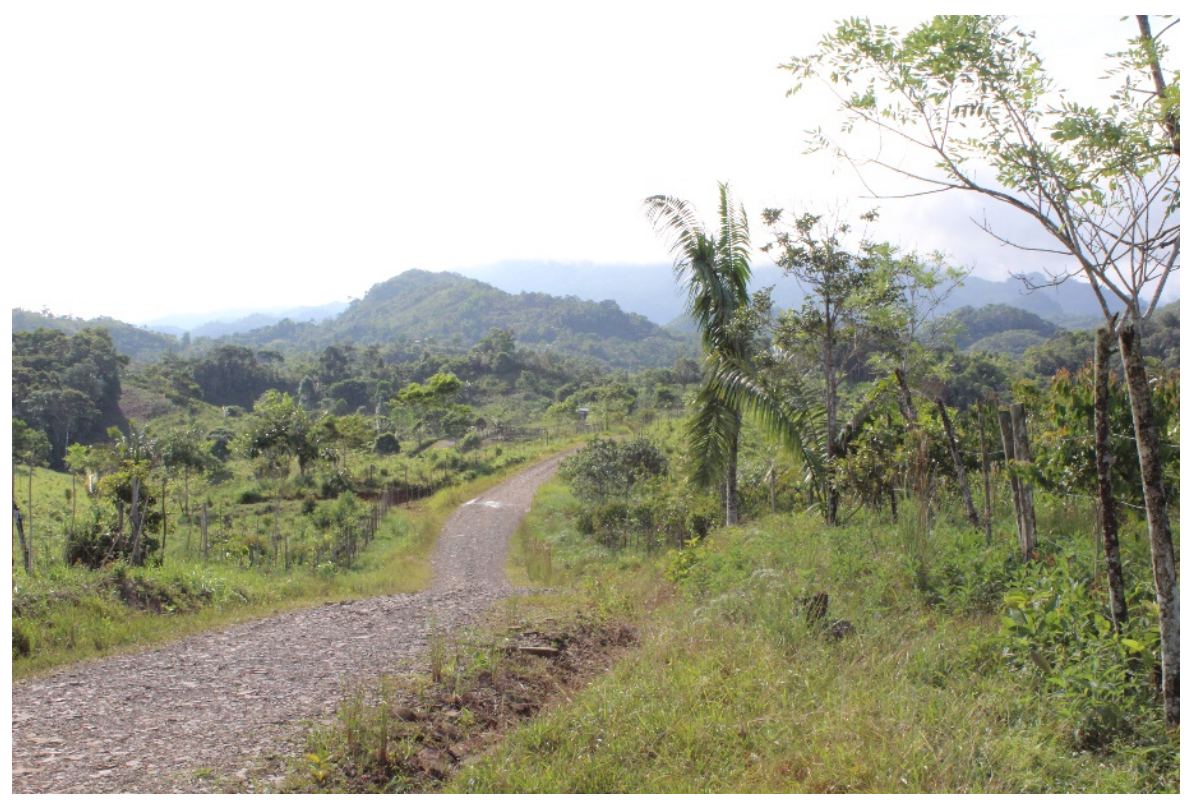

Figure 2. Road leading into Las Claras Arriba, Capira. Photo by Sam Clair

Las Claras Arriba is an entry point for people living beyond the river Rio Indio in the far north of the province of Coclé. These people get to their farms either by foot or by horse, since there are few roads in this area. It becomes especially difficult to access these areas during the wet season when footpaths become almost impassable. 
The majority of homes in Las Claras Arriba are made from wood that is roughly-cut by chainsaws (Figure 3). Some homes have areas with cement floors, but the majority have dirt floors. Palm fronds were used traditionally for roofing, and still are used often for kitchen roofs. Most people these days, however, have zinc roofs for the main parts of their houses. There are no electric lines that run to the community, but several families use diesel generators or solar panels to power lights or television sets.

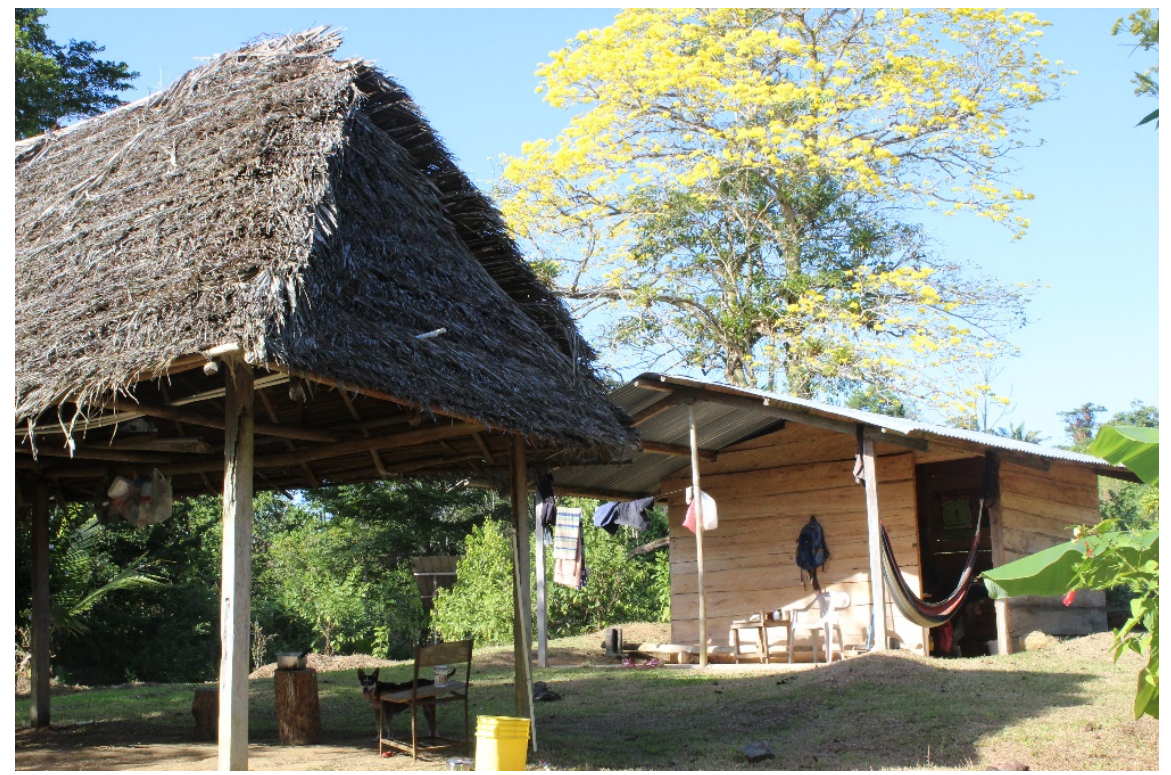

Figure 3. Example of dwellings in Las Claras Arriba. Photo by Sam Clair

La Bonga Abajo, the second community sampled in this study from the district of Capira, is about a thirty-minute ride away from Las Claras Arriba. La Bonga Abajo is located on a paved road, and it is closer to the Inter-American Highway and the larger city of La Chorrera. Material wealth is more noticeable in La Bonga Abajo than in Las Claras Arriba. The majority of homes are composed of cement blocks in La Bonga Abajo, and floors are made from cement. There are more personal vehicles seen around La Bonga Abajo. Most homes have electricity in the form of power lines, and many families have television. 


\section{District of La Pintada: Communities of Piedras Gordas, Las Delicias, El Guavo, Machuca, Membrillar, and Pedregoso}

The district of La Pintada is located north of Penonome in the Coclé Province (Figure 1). This area is more traditional, in the sense that it is farther away from the influence of the nation's capital, Panama City. The population of the district of La Pintada was 25,304 as of 2006 with 13,521 males and 11,783 females (SINAMP 2006). The communities of El Guavo, Machuca, Las Delicias, Piedras Gordas, and Membrillar are located throughout the district, with all having road access. These communities are relatively small. The majority of homes are made from cement blocks. In general, infrastructure is better in these communities than it is in the communities of Capira. Electricity is present throughout La Pintada, as are paved roads that connect many communities to each other. There is a higher level of affluence throughout La Pintada than what is experienced in Las Claras Arriba and La Bonga Abajo. The economy of La Pintada is less subsistence than are the economies of many places throughout Capira. People around La Pintada raise some cattle, grow citrus and coffee, work in construction, and weave sombreros. The climate throughout La Pintada is hot and humid, but slightly cooler at higher elevations.

\section{Participant Observation}

I lived in Las Claras Arriba, Panama for two years (2014-2016) as a Peace Corps Volunteer. This assignment was voluntary and was done in conjunction with working towards a M.S. in Forestry. To learn more about sombreros, I engaged in ethnographic fieldwork, which is the foundation of cultural anthropology. This type of investigation is known also as participant observation. It involves getting close to people and making them feel comfortable with your presence so that you can observe and record information about their lives and gain insight into a culture (Bernard 1995). This method allowed me (the researcher) to use observation, natural conversations, various kinds of interviews (structured, semi-structured, and unstructured), checklists, questionnaires, and unobtrusive methods (Bernard 1995) . 


\section{Interviews}

Prior to interviewing, a list of semi-formal questions was approved by the Internal Review Board at Michigan Technological University (Appendix C). These questions, along with the complete study plan, were also approved by the Panamanian Ministry of Environment, Mi Ambiente and the Peace Corps Country Director of Panama.

Interviews were conducted in Spanish from February through July 2016. Many terms throughout this paper have been translated into English, but Spanish is used for those items that did not translate well. Interviewees were selected either through prior meetings or through the help of Peace Corps volunteers in other communities. At times interviewees were found through chance when no other introduction to a community existed. This happened when I knew that a community had a particular type of weaver, but there was no other way for a formal introduction. To help identify the main plant in this study (Carludovica palmata), a voucher specimen was given to the herbarium at the University of Panama (PMA) for identification. It is labeled Clair 1, access code 0010989; bar code 103820 .

Twenty-one interviews with weavers and fiber processors took place in the communities of Las Claras Arriba and La Bonga Abajo of Capira District from February through July 2016. Twelve interviews took place in the following communities of La Pintada, Coclé: Las Delicias, Piedras Gordas, La Pintada, Membrillar, Machuca, El Guabo, and Pedregoso in March, June, and July 2016. Fellow Peace Corps volunteers lived in many of these communities. This connection allowed for a quicker introduction to the community.

Interview questions were asked in a semi-structured format, so that the interviews retained more the feel of conversations. Not all questions were asked, but only those that were relevant to the conversation. These interviews were not opportunistic, however, and it was made clear by the interviewer that the intent of the interview was to learn about 
sombreros. Since questions were open-ended, participants were able to elaborate as much as they wanted. This format allowed me to ask questions based on participant responses, and it allowed for multiple conversations with the same participant. Follow-up interviews took place when time allowed.

Interview questions were related to the accessibility and management of plants, economic and market issues related to plants and sombreros, and additional questions related to policy and culture of sombreros. Questions were used to more fully understand where fiber was sourced, and if weavers had problems sourcing fiber. Further, questions were used to understand how much weavers earned for their work. Additional questions were used to see the connection that sombreros had to Panamanian culture.

\section{Obstacles}

Since many people in Panama live up to an hour away on foot from a main road, it was necessary to walk to many different homes to set up interview times. Principal weavers were not always present, and so multiple trips to homes had to be made often. At times weavers were unsure of answers to basic questions, such as how many sombreros they produce or even where they obtain their fiber. One well-known sombrero maker did not want to talk very much, and he gave answers contrary to what other community members said about him. This same weaver would say one thing on an occasion and then say something contrary on a different occasion.

Since the intent of the study was to compare sombrero-making between two districts, it was necessary to travel out of the Peace Corps community. The problem with attempting participant observation in an outside community is that it is challenging to build rapport with the people there before conducting interviews. Instead, interviews were done immediately upon introduction since there was not time to build a deeper relationship. This obstacle was assuaged with the help of fellow Peace Corps volunteers who made introductions for me. 
Interviews led me to other communities, where it was said that special types of sombreros were made. These other communities did not have Peace Corps volunteers living in them, so it was necessary for me to introduce myself. This was done by talking to the store owner in the community and then seeking advice as to where the weavers lived. This method worked better than expected, and weavers on these occasions were willing to be interviewed.

\section{Analysis}

Research questions were developed after one year of observation in Panama. Interviews were carried out in two districts, using the questions that were approved by the Internal Review Board as conversation starters. Each interview was recorded in a journal, both from notes taken during the interview and from what was remembered by memory. Each interviewee was given a number code, and information vital to the research questions was entered into an Excel spreadsheet for analyzing. This was done so as to examine trends that were observed in the field.

\section{CHAPTER 4: RESULTS}

\section{Hat Making in the District of La Pintada}

The district of La Pintada is located in Central Panama, in Coclé Province (Figure 1). La Pintada had a history of weaving since before Panamanian independence, starting in at least 1873, when free public instruction of sombrero weaving was enacted into law (Lasso 2013). In 1913, the Professional Women's School was created to provide technical education for women, so they would be prepared to provide work for themselves (Lasso 2013). During the 1970s, sombrero weaving was part of the curriculum in public schools for home education in Coclé province (Lasso 2013).

The "Sombrero Pintado" is the name of the style from the overall region, with production centered in the Districts of La Pintada, Penonome, and Anton. Artisans in this region 
often organize into artisan cooperatives or groups. Examples of this are the Cooperativa Pequenos Productores El Nazarene R.L., in Piedras Gordas; REMAPA, in Machuca; and the Agrupacion Agroforestal El Cope. As of March of 2016, these groups negotiated a loan to purchase land in order to plant parcels of raw fiber material (Grimaldo 2016).

The Sombrero Pintado style is more elaborate than the weave from Capira (described below). A traditional Sombrero Pintado requires parts from several different plants, including: C. palmata (bellota), Astrocaryum standleyanum (chonta), Arrabidaea chica (chisná), Cyperus spp. (junco), and either Aechmea magdalenae (pita) or Furcraea cabuya (cabuya) (Table 1). Since it may be difficult or costly to acquire all these supplies, some weavers are known to substitute certain materials. For example, the black stripe (Figure 4) traditionally is made from A. standleyanum, but dyed C. palmata may be used for an inferior hat.

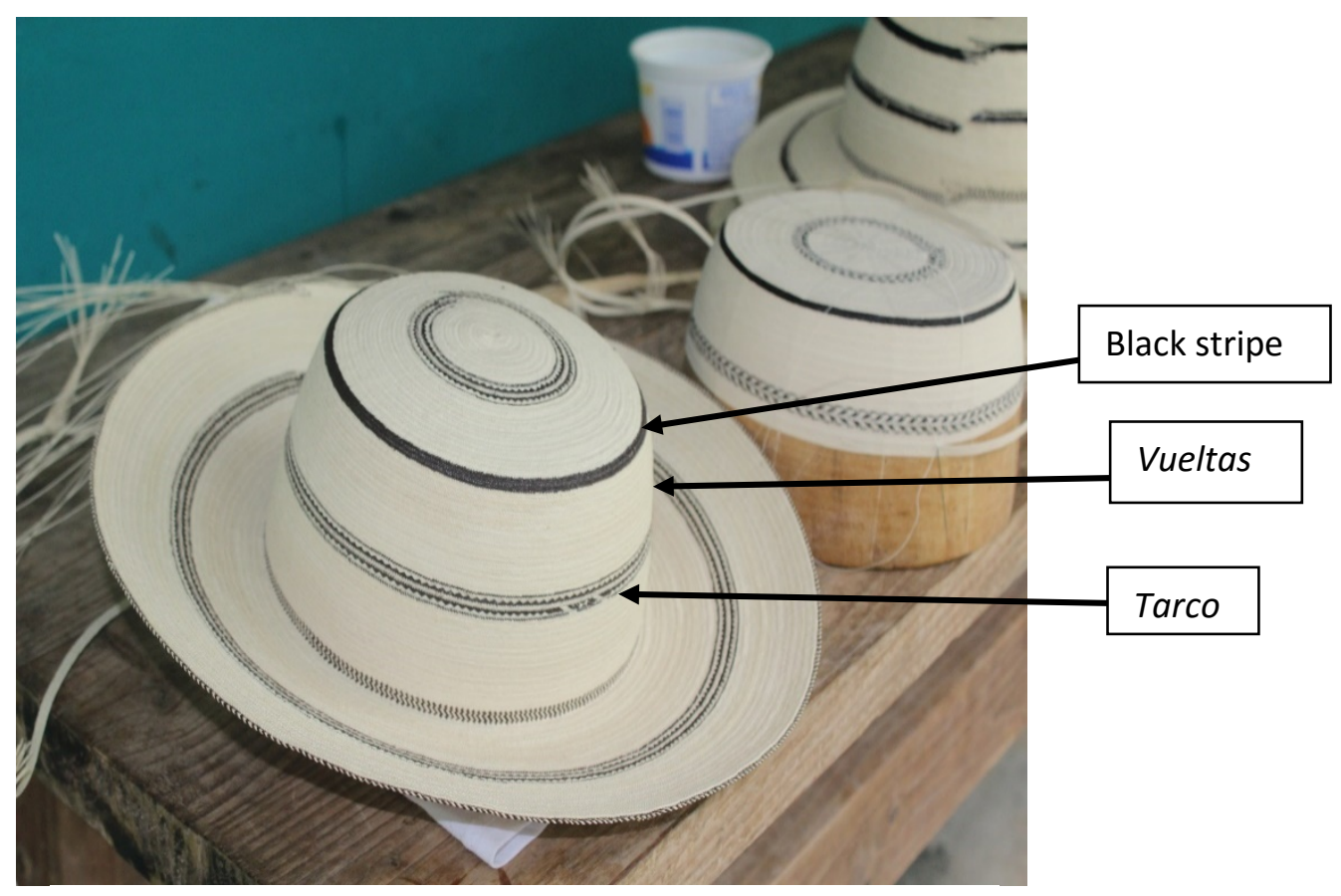

Figure 4. Components of a Sombrero Pintado. Photo by Sam Clair. 


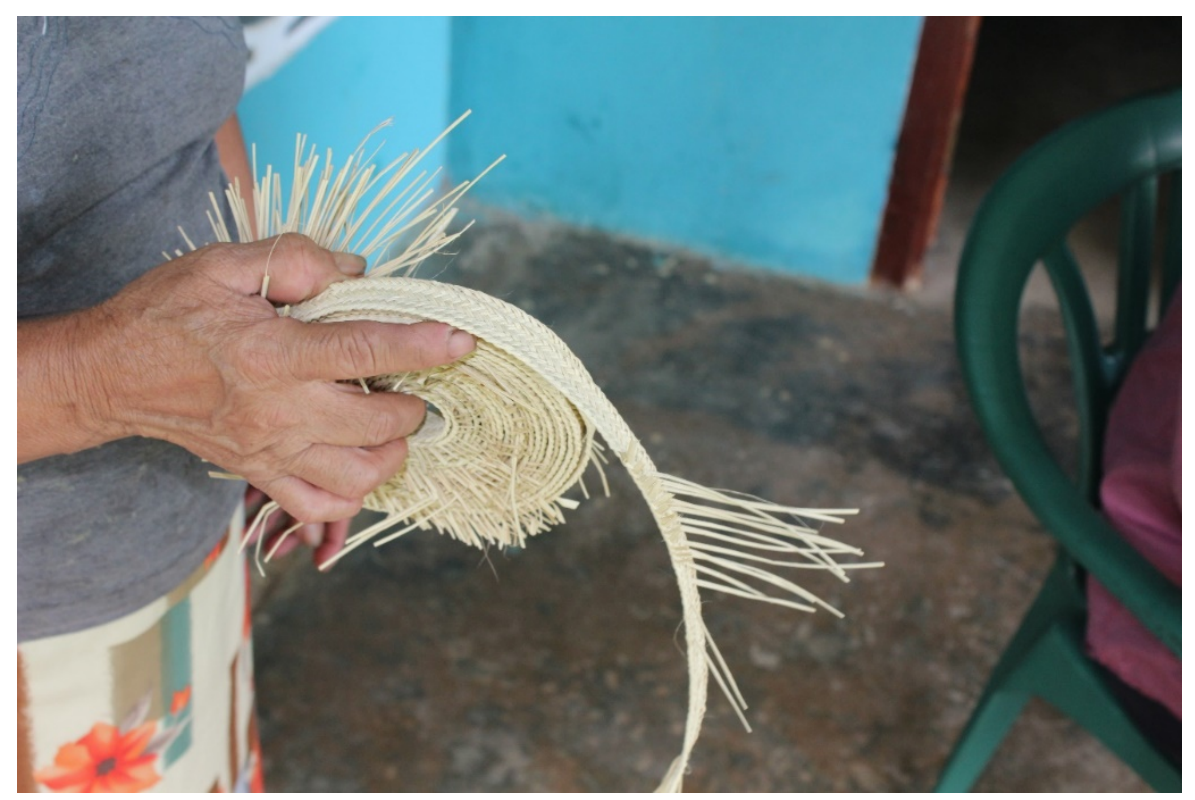

Figure 5. Braided C. palmata that is used for vueltas. Photo by Sam Clair

When weaving a Sombrero Pintado, one often begins by weaving C. palmata into braids. These braids are referred to as vueltas in Panama, and will be discussed as such in this text (Figure 5). When enough braids have been made, these may be sewn together using string that has been processed from $A$. magdalenae or $F$. cabuya (Table 1). The braids are sewn together over a wooden mold made from a soft wood such as mango. While either plant may be used in sewing braids together, F. cabuya is said to hold a firmer brim on the hat. Dyed A. standleyanum is used for black stripes, and dyed Cyperus spp. is used for a black portion called the tarco (Figure 4). The tarco is more ornate than the black stripes, and there are many styles of tarcos made by artisans throughout La Pintada (Martinez 1980). A. standleyanum was observed being used in the tarco, however, since Cyperus spp. can be difficult to find. 


\section{Hat Making in the District of Capira}

The district of Capira is located in Panama Oeste Province, just to the east of Coclé Province (Figure 1). Capira has a style of hat, called the "Sombrero Capireño," where the sombrero is woven all as one piece (Figure 6). Locals refer to this as torsido, pieza, or sombrero parado. The Sombrero Capireño is typically more refined than a rustic Sombrero Pintado. While even a low-end Sombrero Capireño has a higher quality than an ordinary Sombrero Pintado, the Sombrero Capireño also has a much lower price ceiling than does a high-end Sombrero Pintado.

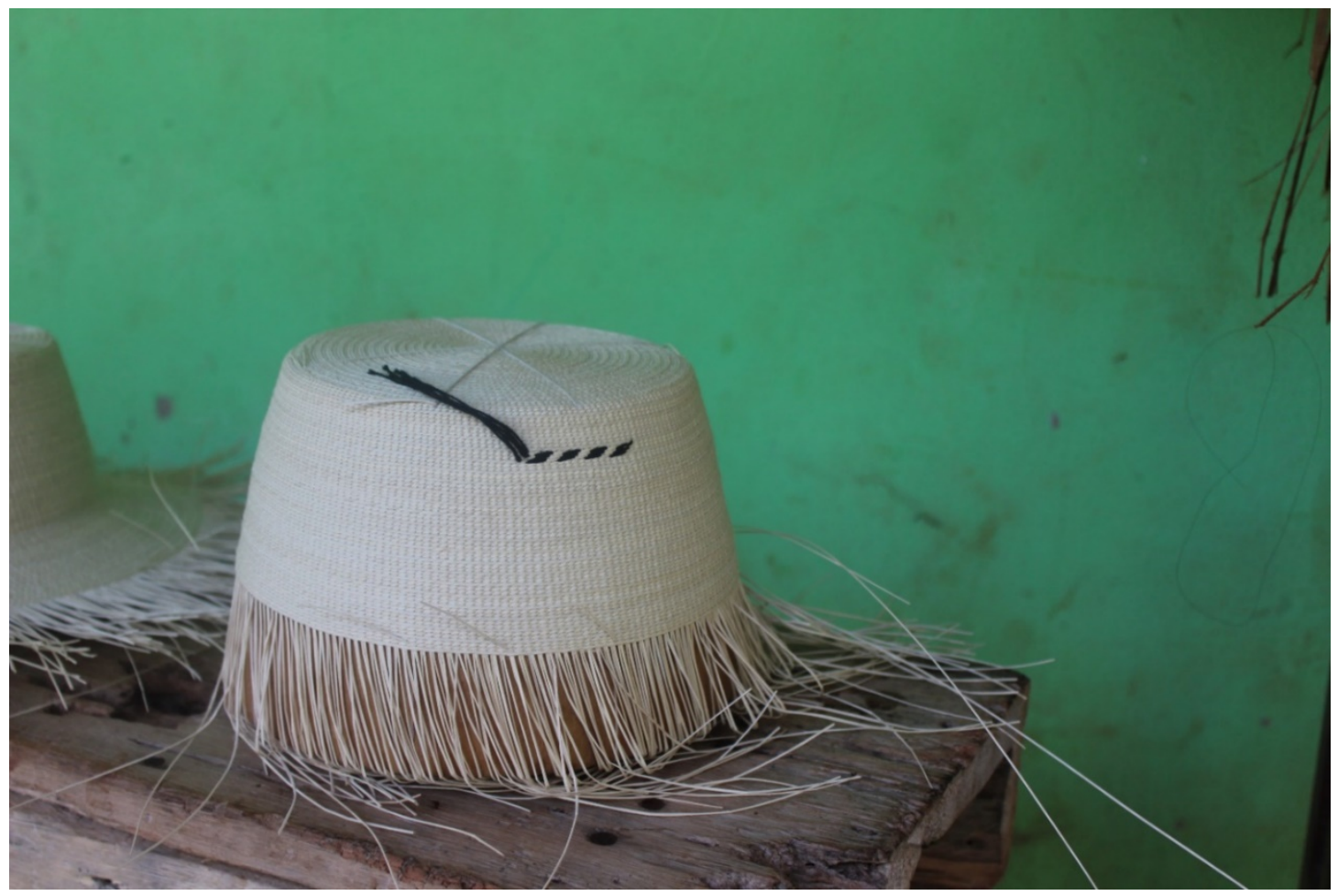

Figure 6. Sombrero Capireño being woven on wooden mold. Photo by Sam Clair

The Sombrero Capireño style (Figure 6) is said to be popular in the Azuero Peninsula, a large peninsula in southern Panama, and is generally not woven or worn around the district of La Pintada. The Sombrero Capireño is often sought by rural transplants living 
around Panama City. A major buyer of these hats are folk singers and musicians who perform traditional Panamanian music in improvised verse.

The so-called "father" of the Sombrero Capireño (who was interviewed for this study) learned to weave in prison from another prisoner who was from the district of Penonome, in Coclé province. When the interviewee was released from prison in the early 1970s, he returned to Capira and began weaving and teaching others. He taught many people in the local schools, so that before long students who attended school were teaching their brothers, sisters, and other family members. Word spread, and by 1978 people in the Las Claras Arriba region were weaving in this style (interview data). Many hat weavers reported learning from their parents, as this tradition is passed down by each generation. A few weavers around Capira, where weaving is relatively new, said they learned by studying previously-made sombreros and trying to emulate the process.

Weavers in Capira have developed what they call a "sombrero pintado" as well, although it is a different weave from the traditional Sombrero Pintados of La Pintada. While the Sombrero Pintado uses at least five different plants, the Sombrero Capireño is traditionally made entirely of C. palmata. The pintado (painted) version of the Sombrero Capireño typically has adornments added to it such as black and white yarn or dyed chonta. Although this hat has black adornments, it is not considered a true Sombrero Pintado within Panamanian culture.

\section{Plants Used in Hat Making}

\section{Carludovica palmata Ruiz \& Pav}

C. palmata is the main component in sombreros in the districts of Capira and La Pintada, and it is what gives these hats their distinctive white color. It is used also for creating change purses, bottle covers, and small sombrero adornments. Although a stronger fiber known as junco is used for making sturdier hats for working (see below), C. palmata is used for more formal hats. C. palmata is a light material that does not hold up well with excess moisture. Sweat will turn the hat yellow, while too much rain will leave the 
sombrero soft and without shape. Given the hot and humid climate of Panama, sombreros do not last very long under frequent use. For this reason, weavers stated that they get repeat business from the same customers.

C. palmata is a perennial tropical grass that looks like a small palm (Figures 7 and 8), and is found wild from Mexico to Bolivia in lowland tropical areas (Espinosa 1998). Leaves are fan-shaped, 1.5 to $4 \mathrm{~m}$ long, with petioles up to $2.5 \mathrm{~m}$ long (Bennett 1992). Adult leaves arise from underground rhizomes and are separated by short internodes (Wilder 1976). According to one study, this plant is thought to be restricted to the edge of forest clearings (Richards 1975). The plant grows well in moist, alluvial soils and it recovers readily from flooding. It does not appear to deplete the soil of nutrients, since plantations in Santa Cruz, Mexico have been growing C. palmata in the same place for over 100 years (Fadiman 2001). 


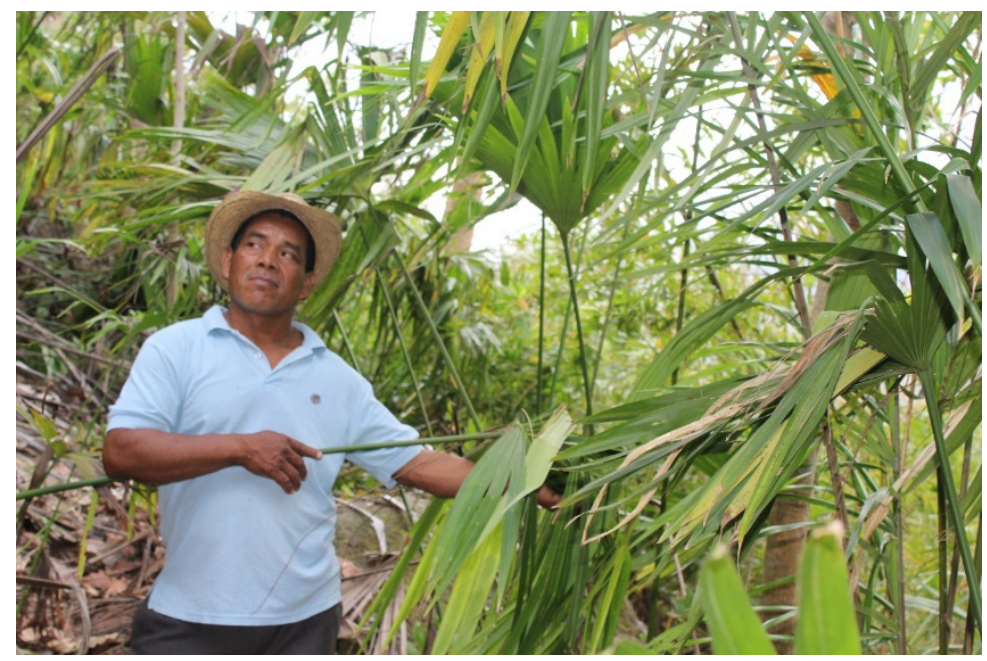

Figure 7. Fiber processor in La Pintada standing with his plantings of C. palmata. Photo by Sam Clair.

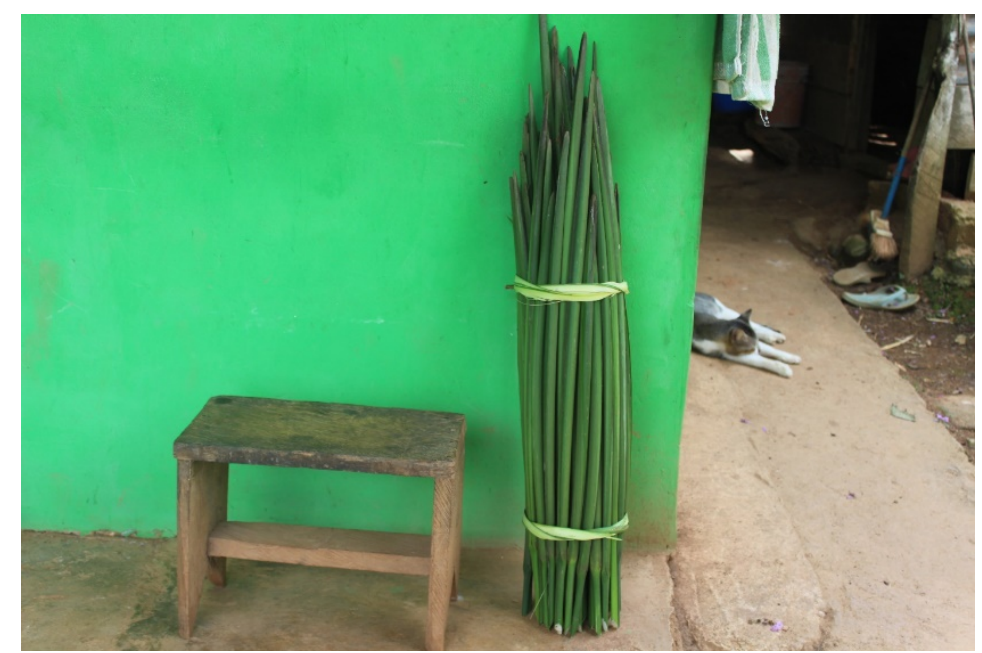

Figure 8. Harvested leaves of C. palmata. Photo by Sam Clair.

\section{Astrocaryum standleyanum L.H. Bailey}

Astrocaryum standleyanum, or 'chonta,' is a plant fiber that is dyed black and interwoven into the Sombrero Pintado. A. standleyanum is used also by the indigenous EmberaWounaan of Panama to weave baskets, plates, and animal masks (Runk 2001). In Ecuador, fruits of $A$. standleyanum are consumed locally, and fibers from young leaves are used commercially for hats, hammocks, mats, and furniture (Pedersen 1994). 
A. standleyanum is a solitary, sub-canopy palm that reaches up to fifteen meters in height and has a stem with flattened, black spines that may reach $20 \mathrm{~cm}$ in length (Runk 2001). A. standleyanum is distributed from Nicaragua through Costa Rica and Panama and then again south to Colombia and Ecuador (Pedersen 1994). This species occurs mainly as scattered individuals within young forests and agroforestry systems, but it is generally not found in pastures (Pedersen 1994). In eastern Panama, A. standleyanum recently is reported to be more difficult to encounter (Potvin 2001). Some studies show this species has trouble regenerating in the absence of agouti (Dasyprocta punctate), which peel and bury the seeds, protecting them from predation and enabling germination (Smythe 1989). It is argued by Potvin (2001) that domestication of $A$. standleyanum can be an easily implemented strategy to prevent extinction of this species under high pressure of use and population declines of agouti.

Fiber is produced from the unopened leaves of the palm, and three to seven new leaves may be produced each year (Pedersen 1994). Leaves may be harvested singly if the plant is short, or the entire palm may be felled if the young leaves are out of reach, although in Ecuador leaves are harvested in a non-destructive way using chisels mounted on long bamboo poles (Pedersen 1994, Runk 2001). To process the fiber for artisan work, first the rachises and middle veins are removed from the harvested, undeveloped leaves. The remaining fibers are washed in cold water, placed in the sun to whiten, boiled with chisná (Arrabidaea chica) until they become red, and then submerged in river mud for two days (Chízmar 2009). When removed from the mud, the leaves are a vibrant black color that provides the 'painted' effect when woven along with the white C. palmata. 


\section{Furcraea cabuya Trel. and Aechmea magdalenae André ex Baker}

Either F. cabuya or A. magdalenae may be used for stitching together the weaves of a Sombrero Pintado. A. magdalenae (Figure 9) is an understory terrestrial bromeliad found in the rainforests of Mexico and Central and South America. The long white fiber that is processed from the leaves of the plant is strong, durable, and resistant to salt water (Kirby 1963). Lincoln (2011) has written about this plant's use in hammocks, baskets, nets, thread, and rope in the Ngäbe society in Panama. F. cabuya (Figure 10) is distributed from Mexico through Central America at low elevations, and its leaves are 1.5-2 $\mathrm{m}$ in length (Zuchowski 2007). The side shoots and bulbils of side branches will grow into new plants, and the plant can be found either wild or cultivated. There are plantations in Central America that produce this fiber to make rope (Zuchowski 2007).

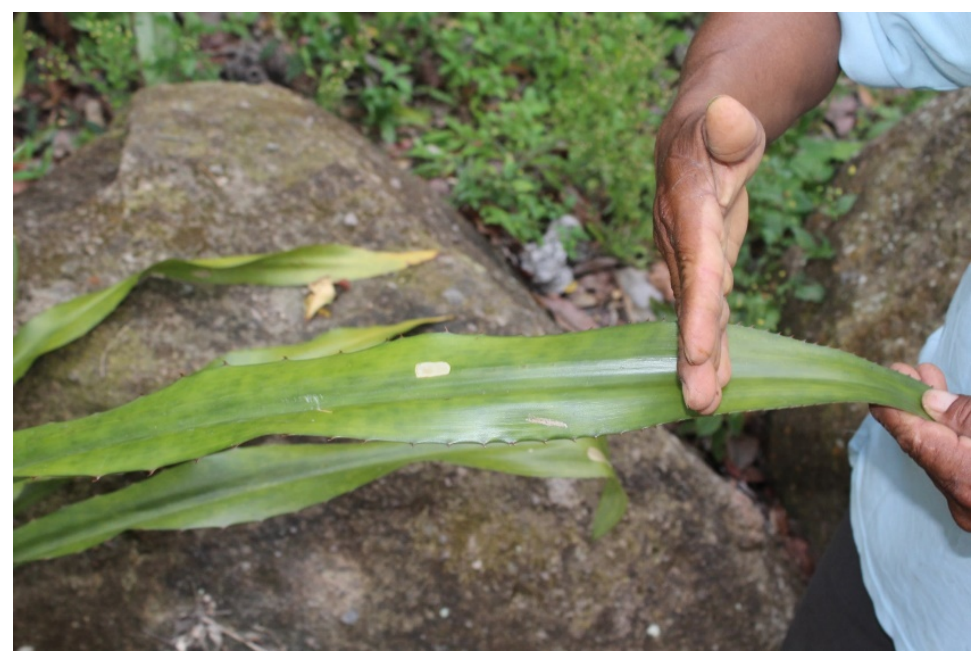

Figure 9. Leaf of Aechmea magdalenae. Photo by Sam Clair 


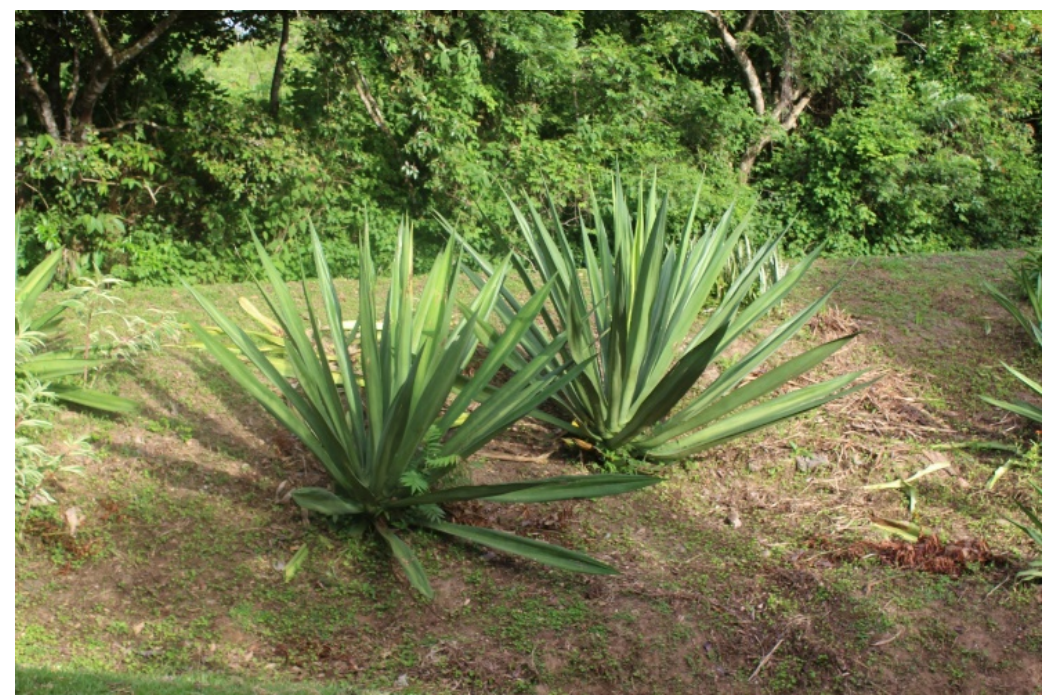

Figure 10. Furcraea cabuya growing in La Pintada. Photo by Sam Clair

\section{Arrabidaea chica (Humb. \& Bonpl. Verl.}

Leaves of Arrabidaea chica (Figure 12) are used as a dye for giving color to $A$. standleyanum, Cyperus spp., and at times C. palmata. A. chica is a woody vine that is cultivated in house gardens throughout tropical America (Vickers 1984). In order to produce a dye, its leaves are grated or crushed in water. In Panama, it is often pounded in a large mortar and pestle (Figure 11). Leaves may be cooked or uncooked to provide a red, dark brown, or black dye (Vickers 1984). This plant also is used as a body paint among the indigenous cultures of the Orinoco and the natives of Amazonian Colombia and Ecuador, and also by the Choco Indians to dye basket fibers black and red (Gentry 1992). 


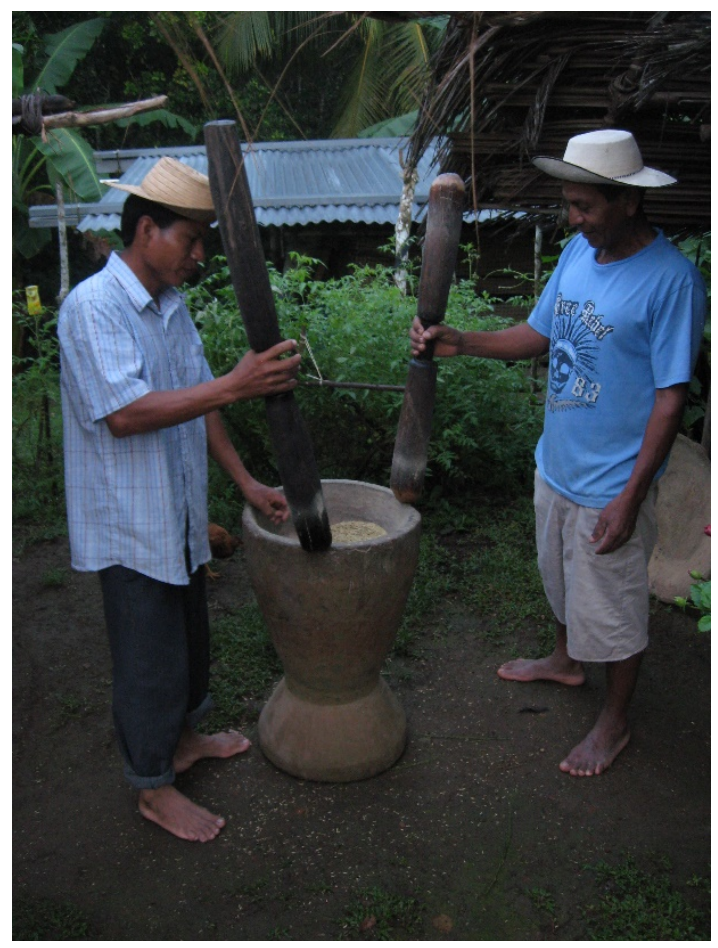

Figure 11. Mortar and pestle used for threshing rice or crushing Arrabidaea chica leaves. Photo by Sam Clair

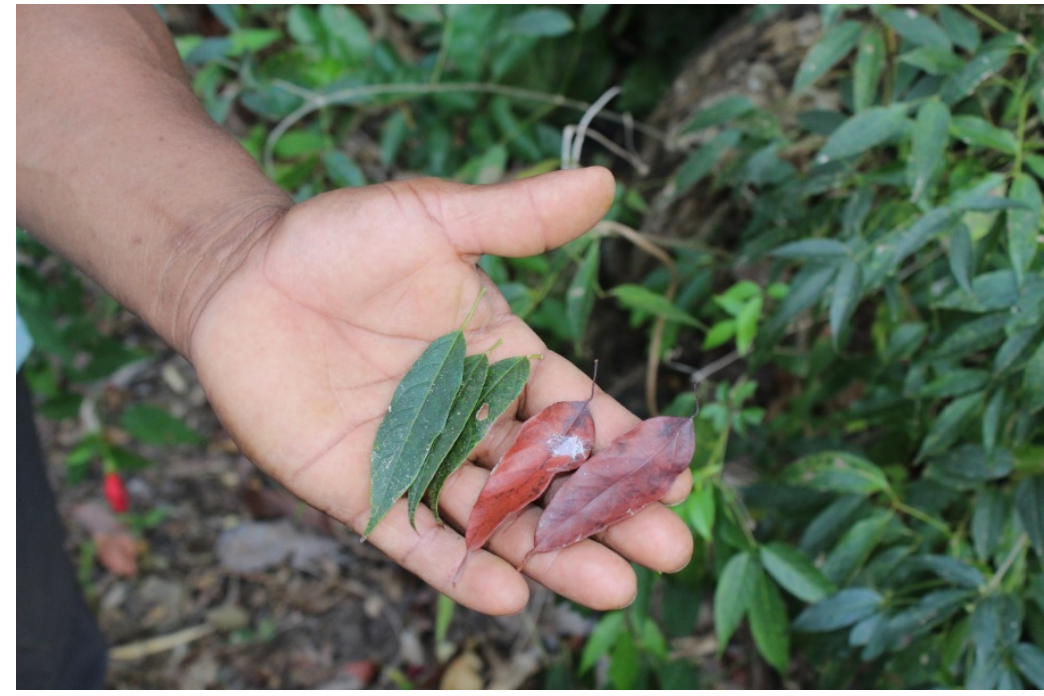

Figure 12. Leaves of Arrabidaea chica. Photo by Sam Clair. 


\section{Cyperus spp.}

Cyperus spp. or 'Junco' (Figure 13) is dyed with A. chica and interwoven with $C$. palmata into the Sombrero Pintado to create a portion of the hat called the tarco (ornate portion of sombrero shown in Figure 4). Specimens of Cyperus involucratus from Central America have been identified previously as Cyperus alternifolius, but that name is properly applied to a closely related species native to Madagascar (Baijnath 1975, Tucker 1983). According to the study by Tucker (1983), there are 41 species of Cyperus in Panama. Cyperus spp. is an annual with a triangle-shaped stem (Lasso 2013). Its leaves are dark green, and the plant can grow taller than one meter (Lasso 2013). The inflorescence is a yellow to chocolate colored spike, and from the stem of Cyperus spp. a cream-colored fiber may be processed (Lasso 2013).

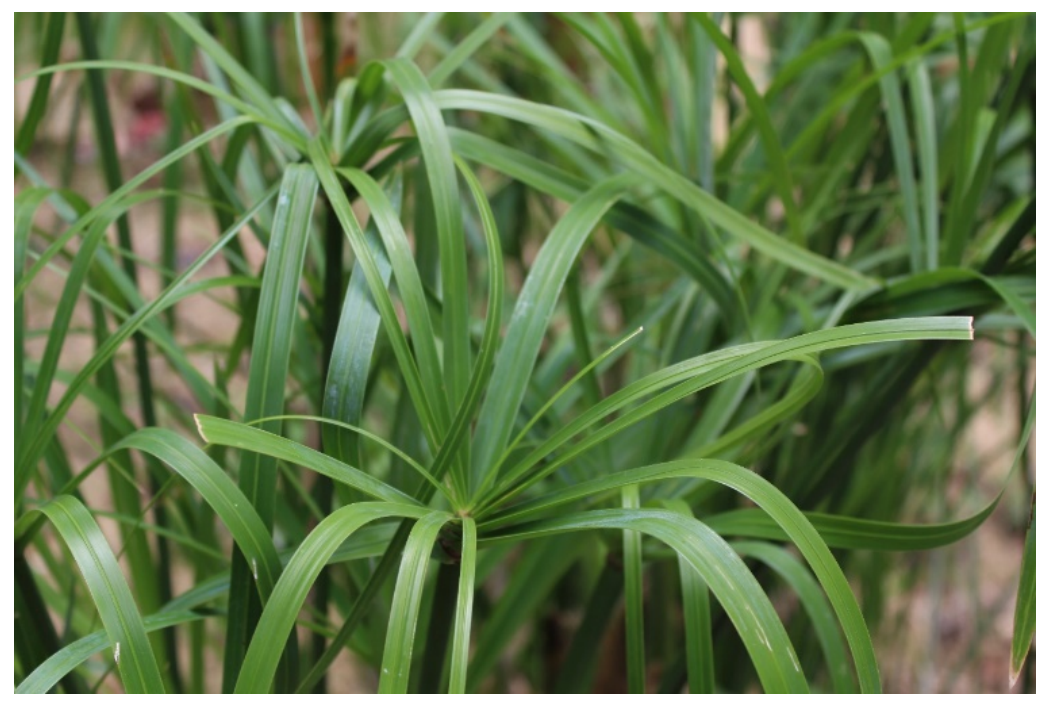

Figure 13. Cyperus spp. growing in La Pintada. Photo by Sam Clair. 
Table 1. Plants Used in Making a Sombrero Pintado

\begin{tabular}{|c|c|c|c|c|}
\hline $\begin{array}{l}\text { Common } \\
\text { Name }\end{array}$ & $\begin{array}{l}\text { Scientific } \\
\text { Name }\end{array}$ & Family & $\begin{array}{c}\text { Type of } \\
\text { Sombrero }\end{array}$ & Use \\
\hline Bellota & $\begin{array}{c}\text { Carludovica } \\
\text { palmata } \text { Ruiz } \\
\text { \& Pav }\end{array}$ & Cyclanthaceae & $\begin{array}{c}\text { Sombrero } \\
\text { Pintado and } \\
\text { Sombrero } \\
\text { Capireño }\end{array}$ & $\begin{array}{l}\text { Leaf fibers are } \\
\text { processed, bleached } \\
\text { white, and woven } \\
\text { together to form the } \\
\text { main portions of the } \\
\text { sombrero }\end{array}$ \\
\hline Chonta & $\begin{array}{l}\text { Astrocaryum } \\
\text { standleyanum } \\
\text { L.H. Bailey }\end{array}$ & Arecaceae & $\begin{array}{l}\text { Sombrero } \\
\text { Pintado }\end{array}$ & $\begin{array}{l}\text { Leaf fibers are dyed } \\
\text { black and woven } \\
\text { with } C \text {. palmata for } \\
\text { painted portion of } \\
\text { sombrero }\end{array}$ \\
\hline Chisná & $\begin{array}{l}\text { Arrabidaea } \\
\quad \text { chica } \\
\text { Humb. \& } \\
\text { Bonpl. Verl. }\end{array}$ & Bignoniaceae & $\begin{array}{l}\text { Sombrero } \\
\text { Pintado }\end{array}$ & $\begin{array}{l}\text { Leaf is crushed and } \\
\text { boiled and used to } \\
\text { dye } A \text {. standleyanum } \\
\text { or Cyperus spp. } \\
\text { black }\end{array}$ \\
\hline Junco & Cyperus spp. & Cyperaceae & $\begin{array}{l}\text { Sombrero } \\
\text { Pintado }\end{array}$ & $\begin{array}{l}\text { Dyed black and used } \\
\text { in traditional } \\
\text { sombreros for the } \\
\text { black portion known } \\
\text { as 'tarco' }\end{array}$ \\
\hline Pita & $\begin{array}{l}\text { Aechmea } \\
\text { magdalenae } \\
\text { André ex } \\
\text { Baker }\end{array}$ & Bromeliaceae & $\begin{array}{l}\text { Sombrero } \\
\text { Pintado }\end{array}$ & $\begin{array}{c}\text { Fiber used as thread } \\
\text { to sew woven braids } \\
\text { of } C \text {. palmata } \\
\text { together. }\end{array}$ \\
\hline Cabuya & $\begin{array}{c}\text { Furcraea } \\
\text { cabuya Trel. }\end{array}$ & Agavaceae & $\begin{array}{l}\text { Sombrero } \\
\text { Pintado }\end{array}$ & $\begin{array}{c}\text { Fiber used as thread } \\
\text { to sew woven braids } \\
\text { of } C \text {. palmata } \\
\text { together. }\end{array}$ \\
\hline
\end{tabular}




\section{Demography of Interviewees}

The most abundant age class of weavers interviewed in Capira were males in the 40-60year range $(50 \%)$ (Figure 14$)$. There were almost as many male weavers in the $20-40$ year range (40\%). The uppermost range, 60-80 years, had the fewest weavers interviewed (5\%). One woman in the 40-60-year range was found who wove with C. palmata. All other weavers interviewed were male.

The most abundant age class of weavers in La Pintada was 40-60 years (69\%). Within this age class $66 \%$ of weavers were female. The second most abundant age class was 20 40 years $(23 \%)$. Females comprised $66 \%$ of this age class as well. The least abundant age class was $60-80(7 \%)$.

My sample size is low for both districts. According to the 2006 census (SINAMP 2006), there were 25,000 people living in La Pintada in 2006. If we assume a low estimate that one-percent of the population weaves, then there should be around 250 weavers in La Pintada. Likewise, Capira should have around 150 weavers if we assume just one-percent of its population weaves (SINAMP 2006). Both numbers are small, but this relates how small my entire sample size of 33 interviewees was. 

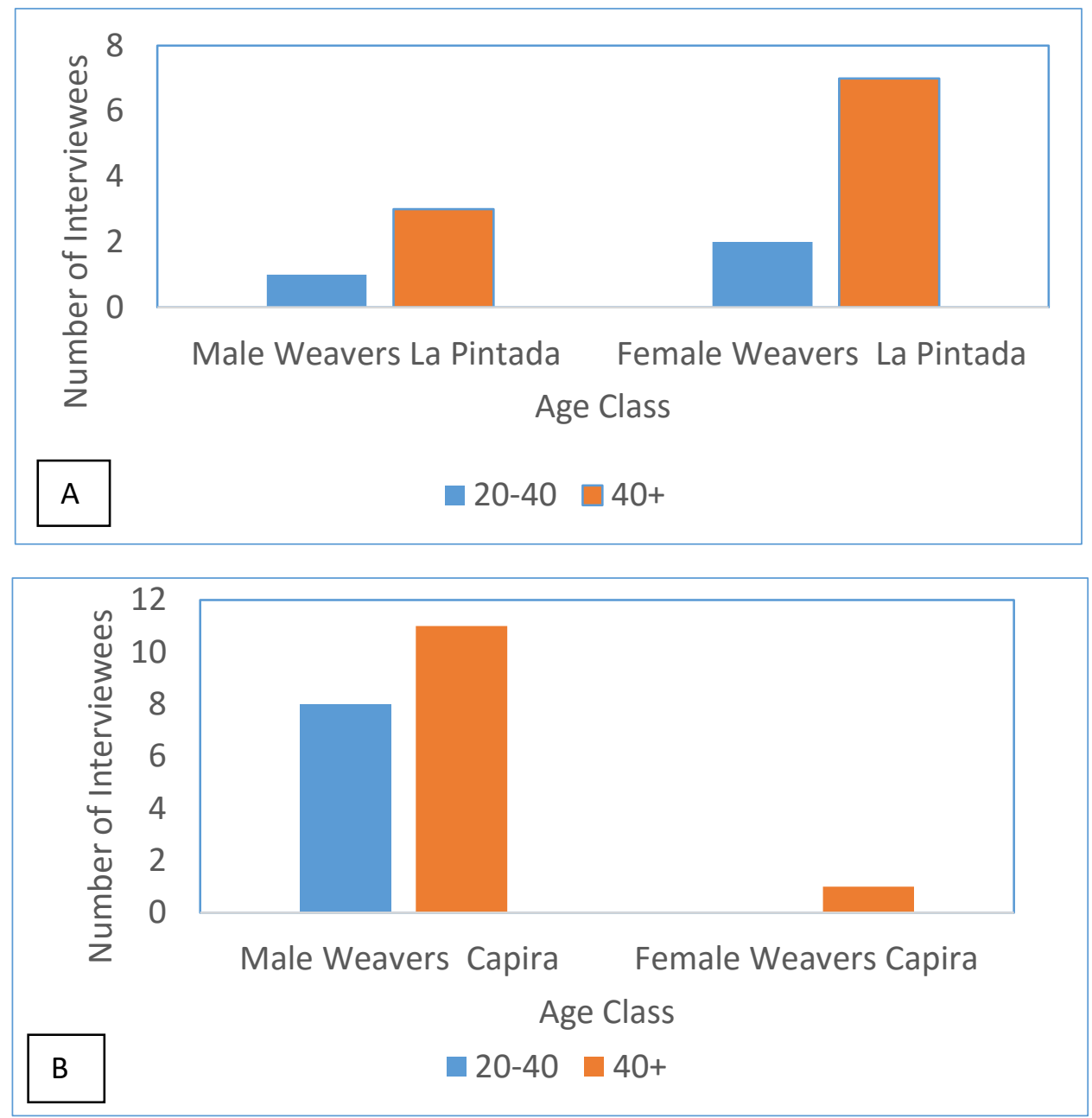

Figure 14. Age classes and gender of weavers interviewed for this study from La Pintada (A) and Capira (B). 


\section{Management of Fiber: Capira}

All weavers in Capira said that they obtained C. palmata from either within their community or from close by, except for one family. This family travelled about four hours one way to Coclé to harvest C. palmata, which was brought back to be processed and sold within the community. This family said they travel to harvest C. palmata because usually there is not enough available within Capira.

In general, stands of $C$. palmata in Capira grew naturally. Management consisted of weeding and transplanting regeneration, but little else. Several weavers had their own naturally-occurring stands of $C$. palmata from which they harvested. These weavers processed what they harvested in order to make their own sombreros, as well as to sell a little. These processors did not indicate a lack of material per se in Capira, but at times it was difficult to find at a short notice. Weavers said they would purchase C. palmata outside their home communities within Capira, but when this happened, they needed to pay more.

Some processors in Capira were unsure of how much fiber they produced. Weavers were also unsure how much fiber was produced in the community, since their source of fiber appeared to change frequently. There did not appear to be any one direct source for those who wanted to purchase C. palmata, and when I attempted to find this fiber to buy, I could not find any available in the community. For this reason, clients will sometimes purchase fiber to supply the weaver with adequate material. While some weavers processed their own material, others around Capira needed to purchase it from processors.

C. palmata was processed throughout the communities of Capira. Weavers here processed their own C. palmata without selling, or sometimes they processed enough to sell. One such processor had a one-hectare farm where he harvested about 60-80 leaves each month. This is enough fiber for him to weave three sombreros each month along with a little extra fiber to sell. As for management, this person used a machete to control weeds around his $C$. palmata when the vegetation became too thick for the plant to grow. 
Although A. standleyanum was used sparingly in Capira, weavers were aware of it. While some communities reported having $A$. standleyanum, other communities reported its scarcity. One processor of $A$. standleyanum reported that he processes about ten leaves per year. He harvested leaves of small plants without killing them, but adult palms needed to be felled in order to reach the leaf. Weavers who lived close to the border of Coclé province reported obtaining $A$. standleyanum from there. Weavers farther away from the Coclé border reported the presence of A. standleyanum in the community, but that the leaves were not harvested.

\section{Management of Fiber: La Pintada}

Many weavers within La Pintada harvested and processed their own material, but some cited ecological factors that prevented them from doing this. Weavers in one area stated that even though most people had their own C. palmata planted, the prolonged dry season made material scarce. For this reason, fiber needed to be obtained from other areas at times. The women of the same area stated that they get material from neighboring communities farther in the hillside when it is not available nearby. There was a government project by the Ministry of Commerce and Industry (MICI) that began throughout La Pintada in 2006, to encourage the establishment of cultivated C. palmata (Lasso 2013). Several participants of this project stated ecological problems, such as the prolonged dry season, that have hampered the success of the government project. One woman said that everything that she planted had since died. Others said that fiber production was diminished by one half during the dry season. For this reason, fiber may be processed and hoarded during the wet season in order to meet fiber demand during the dry season. 
Governmental involvement has worked well in some areas of La Pintada. One cultivator was growing C. palmata in quantity using simple management techniques. After receiving assistance in around 2008, this cultivator had been planting and processing fiber for eight years. He began with help from the Ministry of Commerce and Industry and has continued with what he was taught. He had around 500 C. palmata that he had

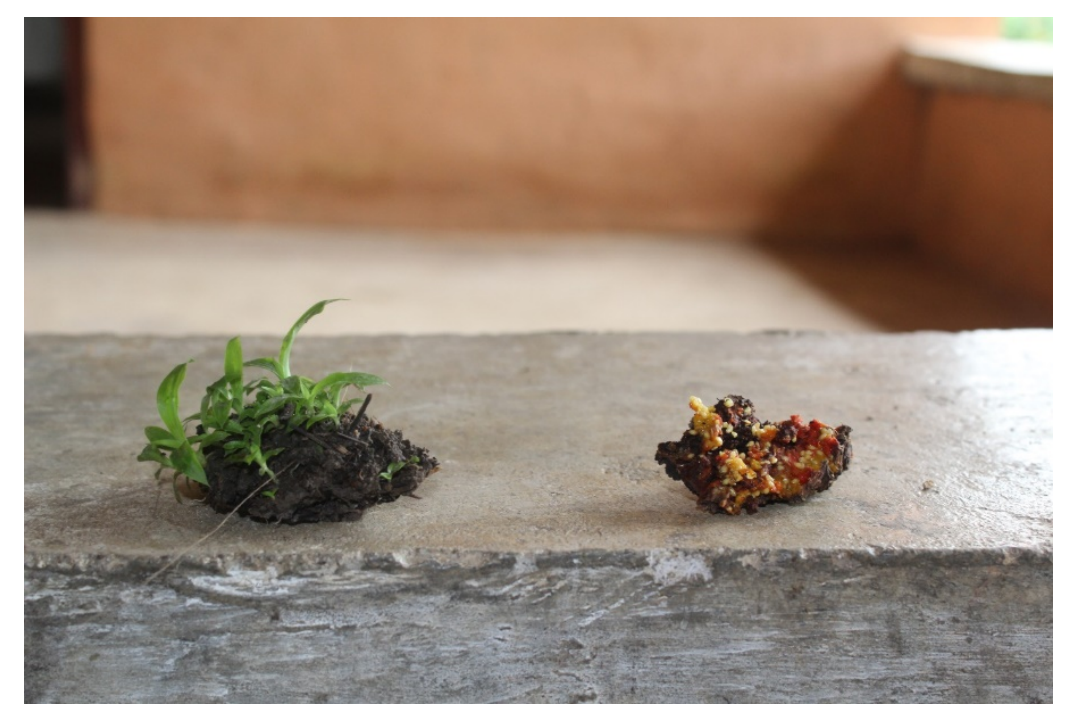

Figure 15. C. palmata seedlings (left image) and seeds (right image). Photo by Sam Clair.

planted between his coffee and citrus crops. This, he reported, was to maintain soil moisture and control erosion. This cultivator demonstrated how he began new seedlings by planting the tiny seeds of C. palmata in his nursery (Figure 15). The seedlings were sold or planted around the property. 


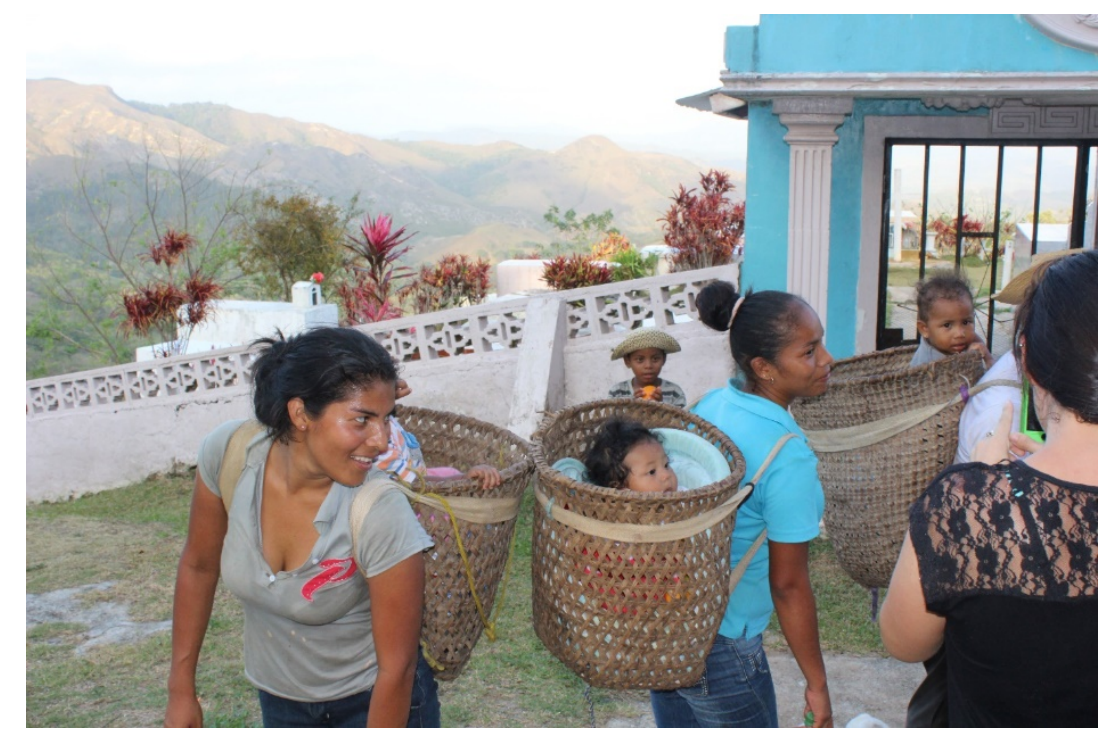

Figure 16. The traditional motete used for carrying harvests from the field, or in this case, small children. Photo by Sam

Clair.

The processor reported that he used to weave sombreros to sell, but that now he farms organically and sells C. palmata. He sold leaves as both processed and unprocessed, with the unprocessed selling for slightly less. He used organic fertilizers to maintain the vigor of plants and to control fungal problems, and he weeded around plants with a machete as he harvested new leaves. He carried a traditional basket on his back, called a motete, into which he placed each cut leaf (Figure 16). He could harvest 300 leaves in a single day working this way, and usually harvested three to four times each month. His 500 or so plants were placed at two meters by three meters distance from each other, from which he harvested between 1000 and 2000 leaves each month. The lower harvest was during the dry season, when plants are flowering and leaves are more scarce. He reported that the more he harvested leaves from C. palmata, the more they grew back.

Other people around La Pintada harvested and processed C. palmata, but to a lesser degree. Interviewees reported harvesting between 60 and 240 leaves per month, with a decrease in leaf production of one-half during the dry season. Even those who cultivated their own fiber reported the need to buy occasionally during the year when they did not have enough. Naturally-occurring stands of $C$. palmata were said to be propagated by the capisucia or choroteca bird (Turdus grayi) that consumes and redeposits seeds. $C$. 
palmata planted from seed was said to require five years before leaves could be harvested.

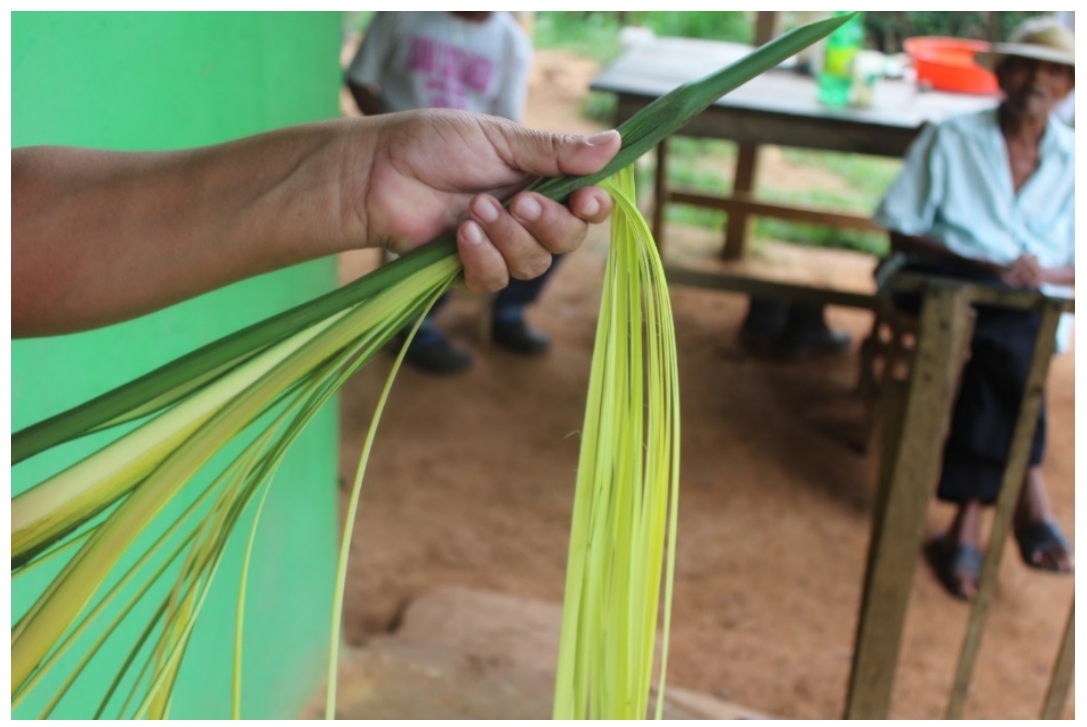

Figure 17. Removing the outer leaves of bellota before it is boiled. Photo by Sam Clair.

\section{Processing and Weaving of Fiber}

C. palmata was processed more or less the same by each person. First, an unopened leaf (cogollo) was identified on the plant. This leaf was cut using a machete. In general, many leaves were cut at the same time. Leaves may be left to cure for three days, whereby they are left untouched, or they may be processed immediately. When processing fiber, first the outer leaves were removed since these are too fibrous to be used for a hat (Figure 17). The inner leaves were softer and thus remained attached to the stem for processing. At this point each leaf may be cut to size using a sharp instrument. The tool used for this may be a fingernail, a metal needle, or a piece of deer bone. Each tool gave a different thickness to the fiber. For example, a deer bone would cut more accurately and more finely than a finger nail, but a metal needle would cut more finely than the deer bone. After the fiber was cut to its desired thickness, it was boiled in water for one to two hours. Some people added soap or lemon juice when they were cooking the fiber, but 
other people did not add anything. Those who did not add anything said that the fiber turned out just as white. For boiling the fiber, a large kettle was placed over an open fire to heat the water. Processors stated that the kettle may be used only for processing fiber. If oil was used in the kettle, or if it was used for cooking food, these will reside in the metal and make the fiber turn yellow.

Once the fiber had been cooked, it may be left in the water to cool and then washed with clean water. Each leaf was placed somewhere to dry in the sun. This may be on a clothes

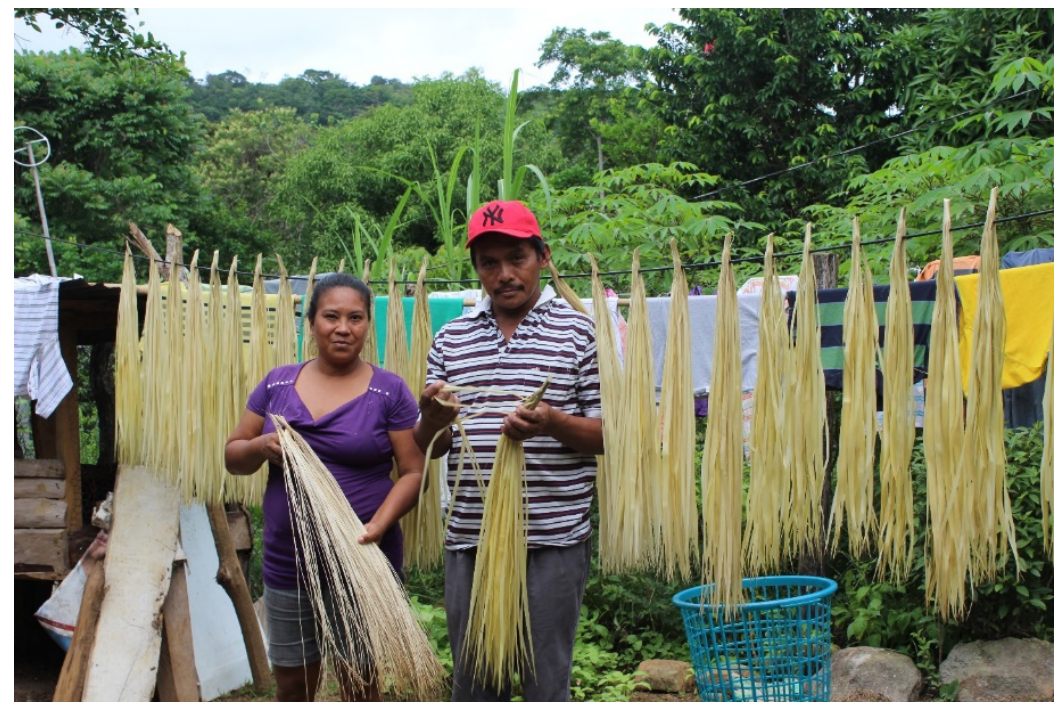

Figure 18. C. palmata drying in La Pintada. Photo by Sam Clair.

line, or it may be on the ground (Figure 18). The important part is that the leaves be moved periodically as they dry, so that they are not touching each other continually during the drying process. It took about eight full days to dry the fiber. During the drying process each leaf curled itself into a thin piece of fiber, perfect for weaving.

C. palmata may be harvested at any time of the year, as long as there are leaves available. The general consensus was that harvest ought to take place during the full moon. Processors said that harvests do take place during the new moon if there is a rush to get material, but that the fiber will not be as white or as durable if it is harvested during this time. Although harvest during a full moon was said to be ideal, other times were said to 
be fine just as long as it was not harvested during the new moon or the eight days following it.

Another consideration was whether one is harvesting in the wet season or the dry season. Leaf production slowed during the dry season when plants were flowering, but there were always plants that were not flowering from which to harvest. Although leaves were reported to be more abundant during the rainy season, it was more difficult to dry them at this time. Even if leaves were harvested during a dry day, there may not be much sunlight following with which to dry the leaves. In this case the leaves needed to be dried under a roof, relying on the air to dry them.

Weavers stated that the best times to weave were during the morning and evening. The ideal times were from 6am to 10:30am, and then again after 4pm. It was more difficult to manipulate the fiber during the hottest part of the day. Many weavers reported back pain associated from excessive weaving, and damage to eyesight was another concern. Older weavers in particular said that they had ceased weaving finer sombreros because they no longer had the eyesight required for the detailed work. It requires many hours of patience to be able to sit and weave small strands of fiber together. For this reason, many weavers said that it is not any person who can weave a sombrero.

\section{Fiber Prices}

Not all weavers in Panama had access to plant fiber or had the knowledge of how to process their own fiber. For this reason, many people purchased material. The cost of fiber affects the overall profit that a weaver received from a finished product. Scarcity of fiber may also drive the quality of sombrero a weaver can produce, since more fiber is needed to make a higher-quality hat. Weavers reported that fiber processors were aware of the value of fiber, and so have been increasing the cost of it in recent times. Processed C. palmata was sold per leaf, which consists of various strands of cut and dried fiber. In general, at least twelve leaves were needed to make a sombrero, and this number may increase greatly depending on the size and the quality of the hat. 
In Capira the price for a processed C. palmata leaf ranged from $\$ 0.10-\$ 0.75$, while in La Pintada the average price was about 33\% lower (Figure 19), and ranged from $\$ 0.17$ $\$ 0.33$ per leaf. Unprocessed leaves were also sometimes sold for around $\$ 0.14$ per leaf.

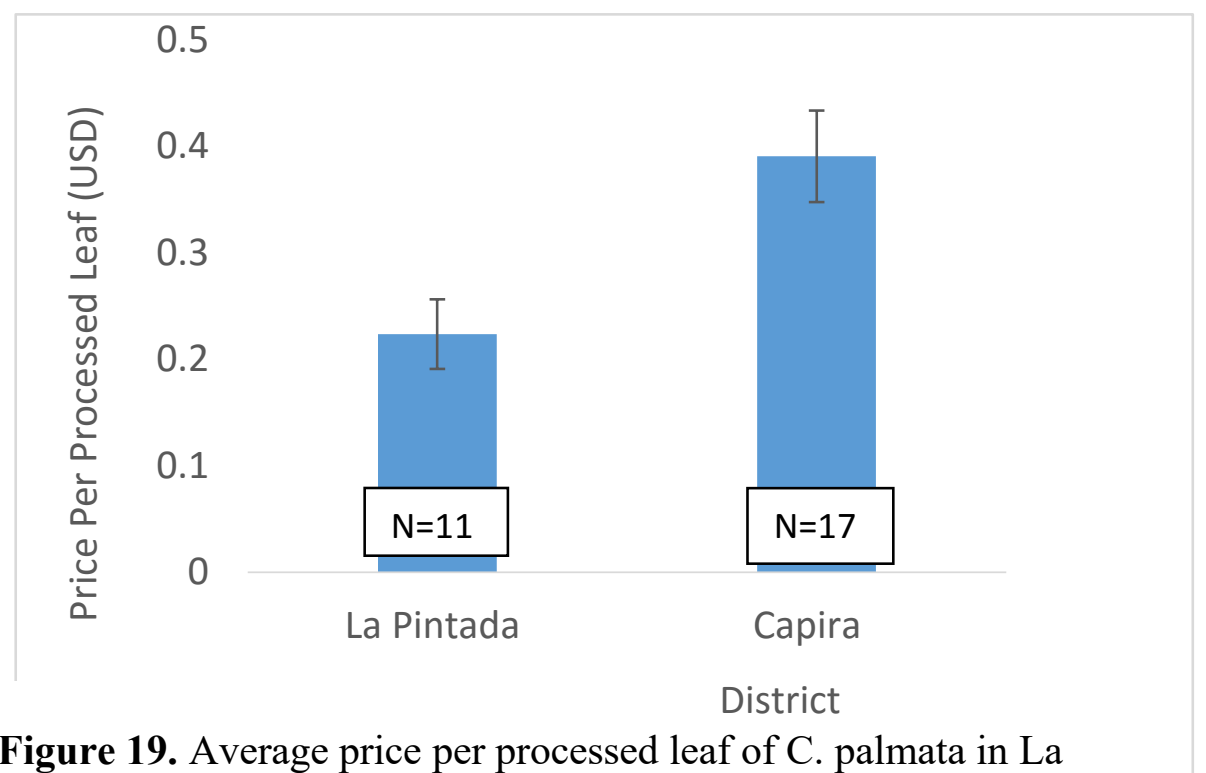

Figure 19. Average price per processed leaf of C. palmata in La

Pintada and Capira. Bars represent standard error of the mean.

\section{Sombrero Prices}

If fiber costs have been rising, it is possible that sombrero prices have been rising as well. Sombrero prices sometimes were linked to day wages. This means that weavers set a daily wage for themselves in terms of days required to weave a sombrero. Other times weavers sold a sombrero for whatever could be earned from it. Prices reflected the ability of the weaver, the available market, and the profit goals that the weaver had. Government initiatives to raise the value of sombreros in recent times was said to account for the price increase that had taken place.

\section{How Vueltas Determine Sombrero Prices}

In general, the number of braids (vueltas) that a sombrero had in the cup portion determined the fineness of the sombrero. Both the Sombrero Pintado and the Sombrero Capireño were classified by the number of vueltas (Figures 20-23). Since each sombrero had a distinct weaving style, the number of vueltas for a Sombrero Pintado meant 
something different than it did for the Sombrero Capireño. For example, a rustic Sombrero Capireño had around fifteen vueltas, while a rustic Sombrero Pintado was considered to be between five and ten vueltas (Figure 20). The finest Sombrero Capireño had twenty-four vueltas, while the finest Sombrero Pintado topped out at about twentyone vueltas. A sombrero with more vueltas not only took longer to produce, but it was more taxing on the body of the weaver and on eyesight. These factors were considered when setting the price.

A finer hat typically had more vueltas, but this was not the only factor in determining the quality of the hat. Other factors such as the whiteness of the fiber, the evenness of the weave, and how meticulous the weaver was in trimming and smoothing excess fiber could determine quality. A sombrero that met these criteria and had a high vuelta count would fetch the most money for the weaver.

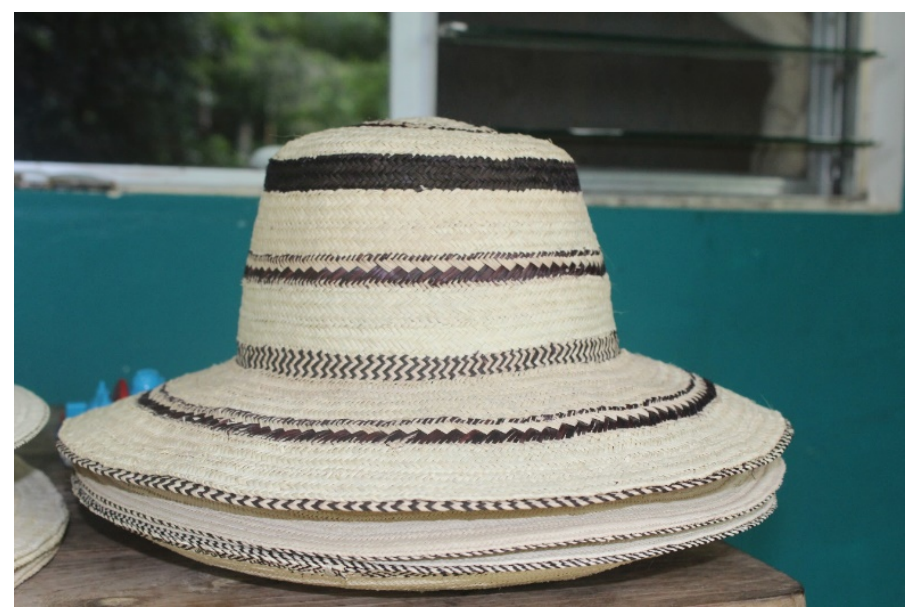

Figure 20. Ordinary Sombrero Pintado with seven vueltas. Worth $\$ 35$ on National Market. Photo by Sam Clair. 


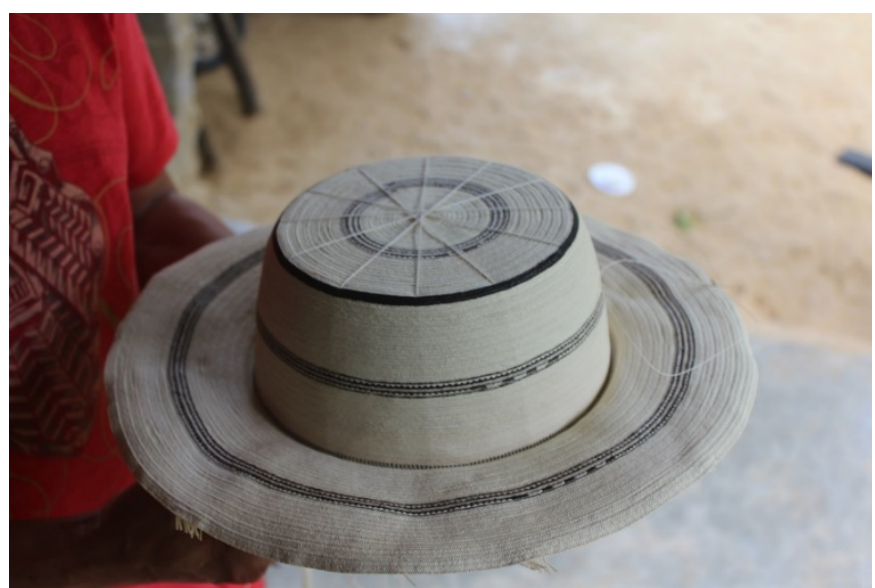

Figure 21. High-end Sombrero Pintado with twenty vueltas being sold for $\$ 900$. Photo by Sam Clair.

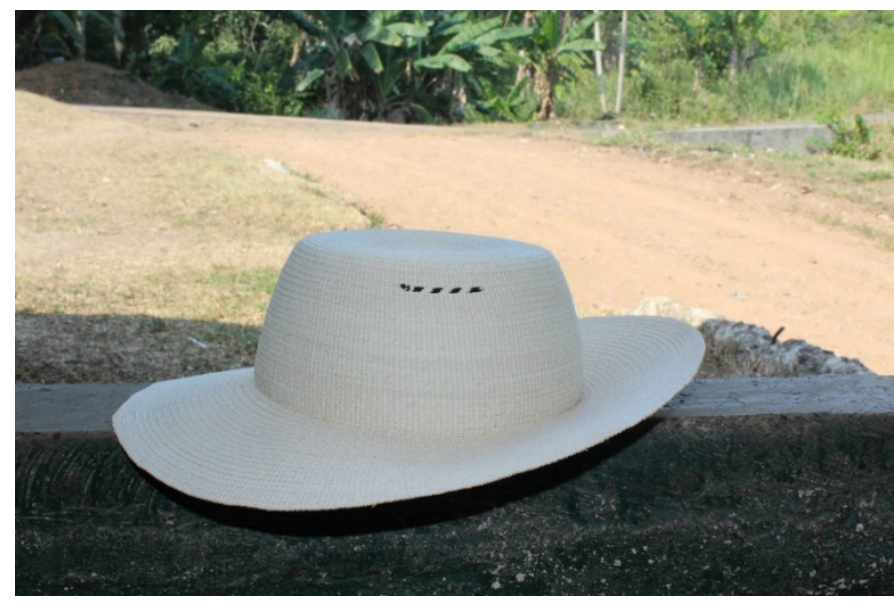

Figure 22. Higher-end Sombrero Capireño. Sells for about $\$ 120$. Photo by Sam Clair. 


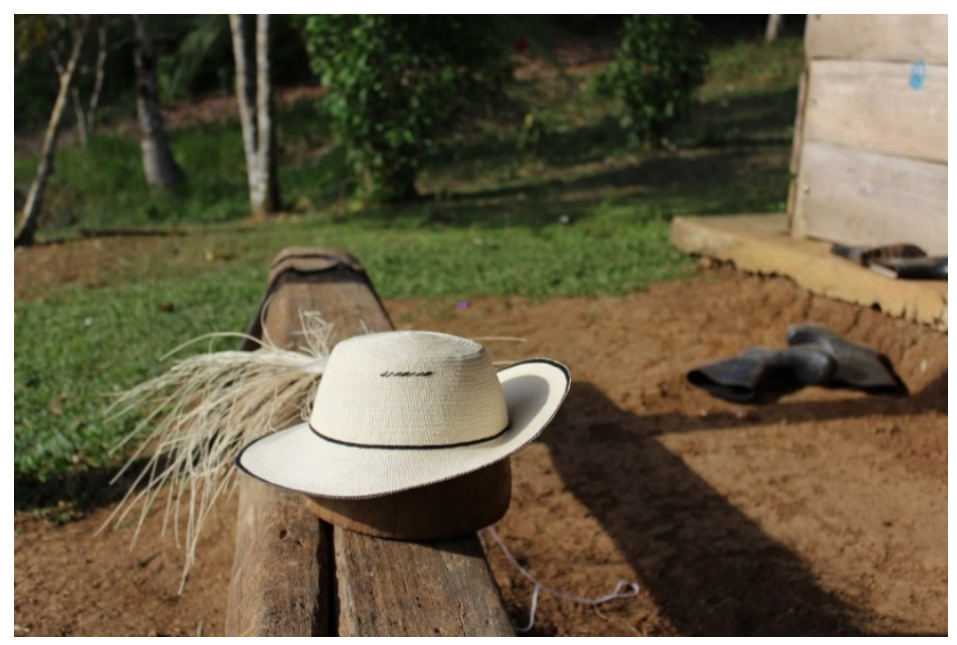

Figure 23. Typical Sombrero Capireño sells for around $\$ 80$. Photo by Sam Clair.

\section{Sombrero Prices Between Districts}

Sombrero prices in La Pintada were more variable than were prices in Capira (Figure 24). Sombreros in Capira began at about $\$ 80$. This price was based on the daily wage (ten dollars) and the number of days required to finish a sombrero (eight days). This did not account for the time required to harvest and process fiber. The finest hats in Capira were reported to be $\$ 180$. 
Weavers in La Pintada reported selling sombreros from between $\$ 6$ and $\$ 900$. The difference in price was based on marketing channels and quality of sombrero. The lowest earning came from rustic sombreros that were sold to intermediaries, while the highest prices came from finely-made sombreros that were sold directly to the customer.

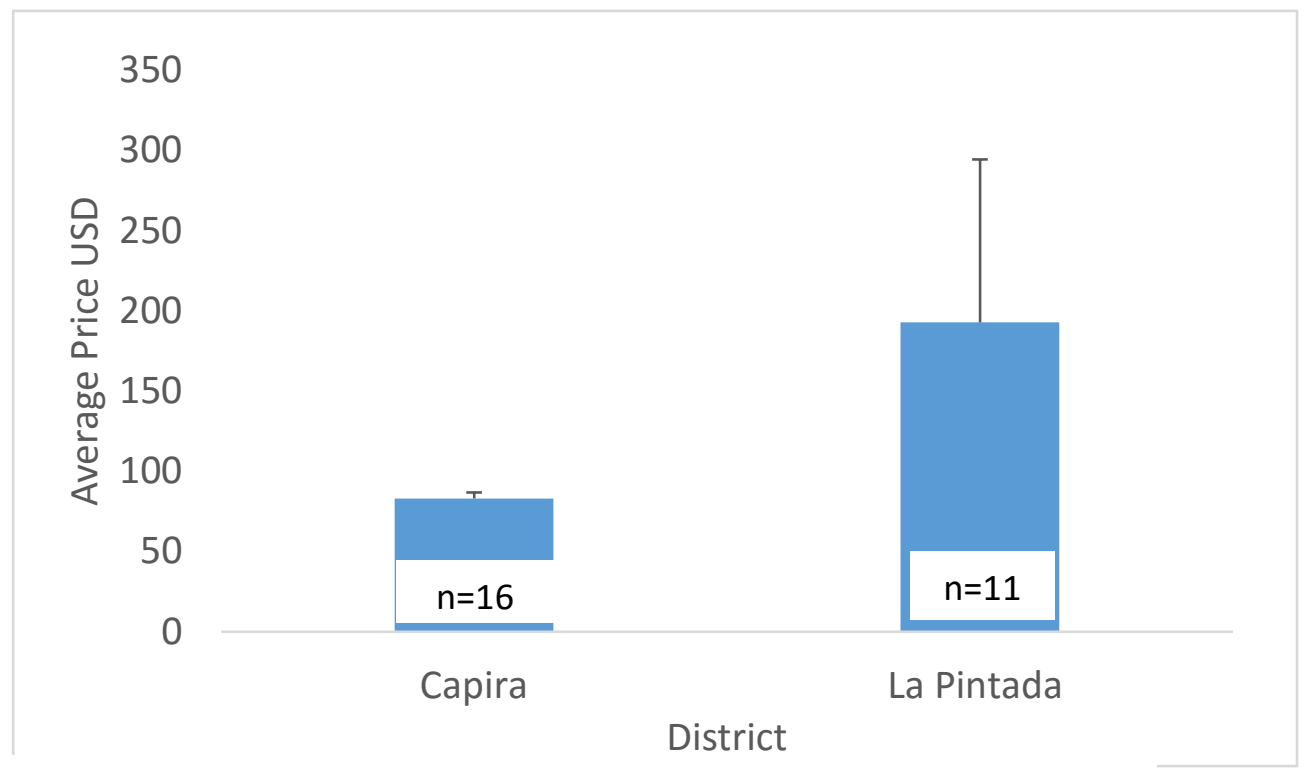

Figure 24. Average sombrero prices between Capira and $\mathrm{La}$ Pintada. Bars represent standard error of the mean

\section{Sombrero Prices by Age and Gender}

Men treated weaving as a way to earn an income. Male weavers stated that sombrero sales were a good way to earn money in between finding other forms of work, or as a full-time occupation. Of those men who wove full time, they set a price that was comparable to what they would earn in other employment. Women, on the other hand, appeared to weave less for profit. Instead, women said more often that they wove out of tradition. Perhaps the goals of women were different, too, in what they earned from sombreros. Women were shown to earn much less from sombreros than did men in $\mathrm{La}$ Pintada District. It was more difficult to quantify what women earned in Capira District, since women were less involved with market sales in this region. The average price earned for women in La Pintada was fifteen dollars, while men earned an average of $\$ 667$ per sombrero (Figure 25). Men in Capira earned about $\$ 80$ on average (Figure 25). A 
small sample size of interviewees, however, may mean that these earning amounts are skewed.

Weavers in both age classes had similar earnings within districts (Figure 26). In general, earning potential was higher in La Pintada but much more variable. Earning potential was lower in Capira, but prices were steadier. Average earnings decreased slightly in both districts for the interviewees aged 40 and older. 

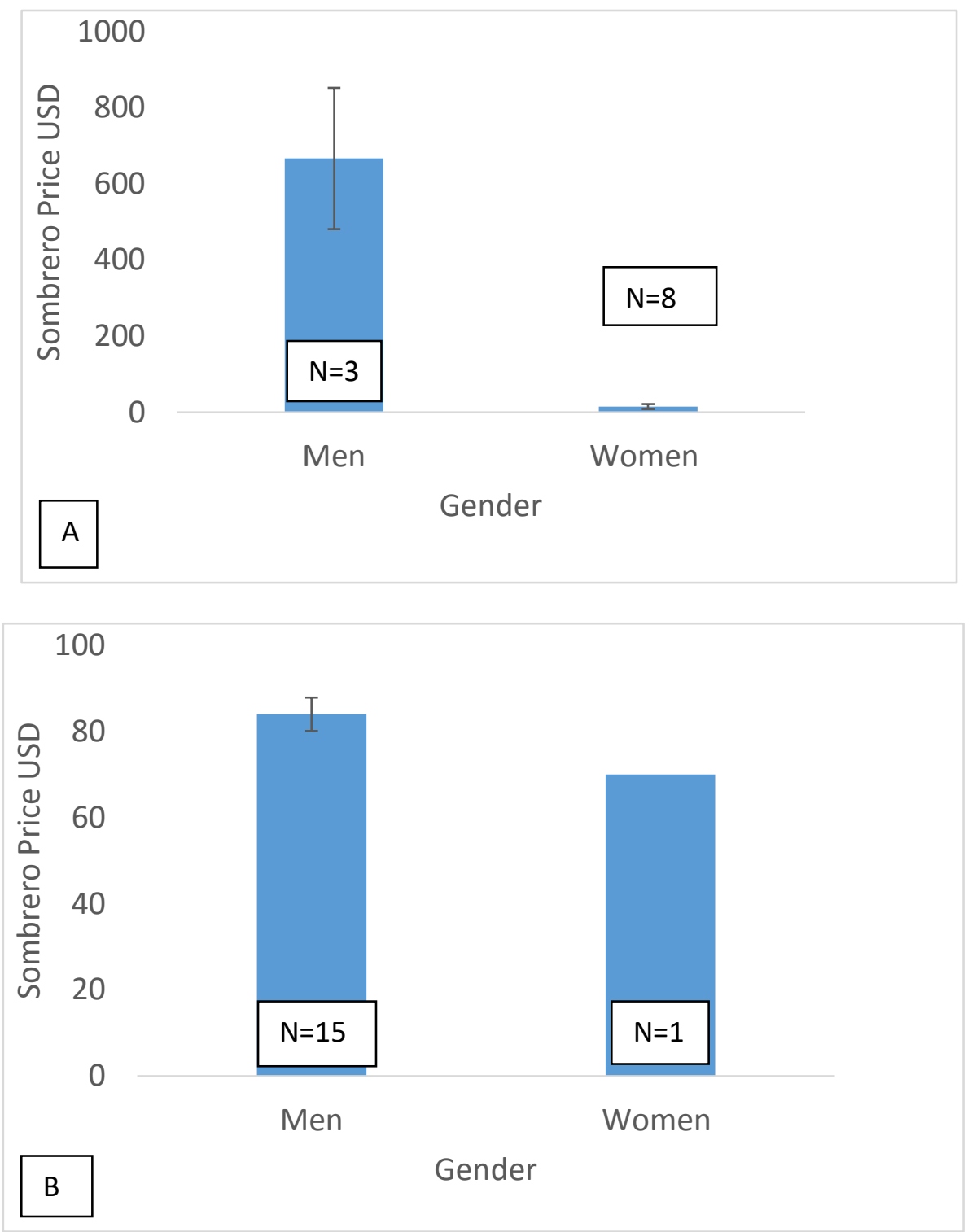

Figure 25. Average Price of Sombreros for Male and Female Weavers in La Pintada (A) and Capira (B). Bars represent standard error of the mean. 

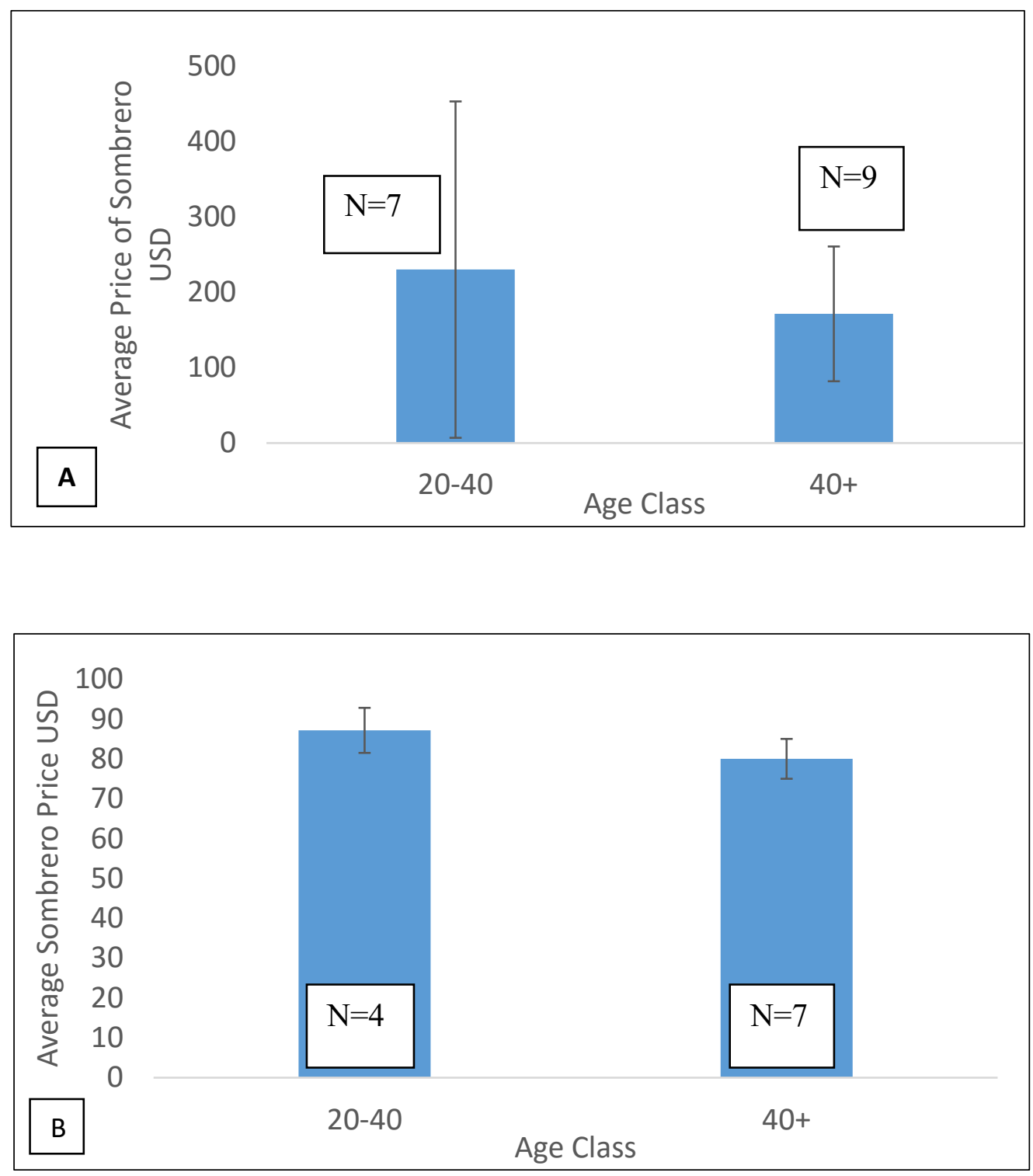

Figure 26. Average Price of Sombreros by Age Class for La Pintada (A) and Capira (B). Bars represent standard error of the mean. 
It was difficult to quantify economic differences between men and women within a district given that more women were encountered in La Pintada and more men were encountered in Capira. Therefore, I attempted to compare earnings for men and women across districts. Male Weavers in Capira appeared to devote more time to weaving than did the majority of women in La Pintada. When weavers in Capira said a hat required eight days of work, they treated this like eight working days, not just when they could fit the time into the day. Given that a day of work is at least six or seven hours, we can expect the minimum amount of time required to make an $\$ 80$ hat to be in the 60 -hour range. In contrast, women in La Pintada who were weaving five vuelta sombreros were spending closer to 25 hours weaving a seven-dollar hat. Even if we account for a man who takes 80 hours to weave a sombrero, his earnings are almost four times that as what a woman would make from her work in La Pintada (Table 2).

Table 2. Comparing Earnings per Hour for Male Weavers from Capira to Female Weavers of La Pintada.

\begin{tabular}{llll}
\hline Gender & $\begin{array}{l}\text { Time } \\
\text { Involved } \\
\text { (hours) }\end{array}$ & $\begin{array}{l}\text { Price } \\
\text { (USD) }\end{array}$ & $\begin{array}{l}\text { Wage } \\
\text { per } \\
\text { Hour } \\
\text { (USD) }\end{array}$ \\
\hline Female & 25 & 7 & .28 \\
Male & 80 & 80 & 1.00 \\
\hline
\end{tabular}

\section{Intermediary Prices Compared to Direct Prices}

Weavers in La Pintada reported that they earned more by selling hats directly to a customer than by selling to an intermediary. For example, while a seven vuelta hat would sell to an intermediary for fifteen dollars, it could be sold directly to a customer for twenty dollars.

Men in Capira reported that sombreros sold to fellow community members were sold for around $\$ 80$, but that sombreros were sold for more if the customer was from outside the community. Several weavers raised the price if they needed to travel to meet the 
customer. Some weavers would not travel, and instead relied on the customer to make arrangements to get the hat. Weavers were willing to compromise prices when selling to an intermediary. Some weavers in Capira reported that the intermediary paid more than local community members, but still paid less than a direct customer from outside the community. As an example, the weaver may sell a $\$ 150$ sombrero to an intermediary for $\$ 130$. This is so the intermediary can make a profit. Weavers in Capira seemed fine with this arrangement, because they were still receiving more for their work than if they tried to sell in their own community. Furthermore, the intermediary supplied a steady market for selling sombreros.

Weavers in both districts said that they got their start by word of mouth. Once a weaver begins weaving and selling sombreros, people start to take notice. If a man is wearing a well-made sombrero, it is likely that other people will ask him where he got it and who made it. These types of conversations can spark additional business for the weaver.

Selling to an intermediary was not always ideal, but it did provide a reliable place to sell sombreros. Markets were constricted within a small community, so weavers required a way to get their hats to a larger market. High-end weavers were able to reach this outside market because there was demand for their hats and low competition. While these sombreros were too expensive to be affordable within the community, Panamanians from elsewhere in the country would travel to the interior to buy a high-quality sombrero.

Interviewees said that the finest sombreros were sold to people from the Azuero province. When sombreros travel from one province to another, so does the reputation of the weaver. Clients may travel to visit the weaver, get their head measured, and make a deposit on the sombrero for while it is being made. Weavers said the deposit was important, especially for high-end sombreros, because they could be difficult to sell if the client backs out of the deal.

Sombreros were sold also to a hat-finisher. This person buys roughly-made sombreros from an intermediary with the intent of increasing the value. By removing excess fiber 
and ironing the sombrero, the finisher could enhance the appearance and the comfort of the sombrero. This allowed the finisher to make a profit from his work, even though he had to buy the sombrero from an intermediary. For example, the finisher may pay sixteen to eighteen dollars to an intermediary to purchase a rustic sombrero. After fixing minor defects and improving the sombrero's appearance, the same sombrero may be sold for $\$ 35$ to $\$ 40$ at the finisher's house or at an artisan fair.

\section{National Sombrero Market}

The Panamanian government sponsors artisan fairs throughout the country. Perhaps the largest of these is the artisan fair at the Atlapa Convention Center in Panama City. Artisan goods from across the country were sold here. To be a vendor, a license was required by the Panamanian government. This license gave special status to the artisan, and it allowed that artisan to resell hats made by other people at the fair. Prices at the national level for different classes of the Sombrero Pintado are in Figure 27. Sombreros here ranged from seven to twenty vueltas, and were priced between $\$ 35$ and $\$ 800$. A sombrero finisher at the fair reported what he paid for unfinished sombreros (Figure 27). For seven to fourteen vuelta sombreros this finisher paid between $\$ 16$ and $\$ 200$. 


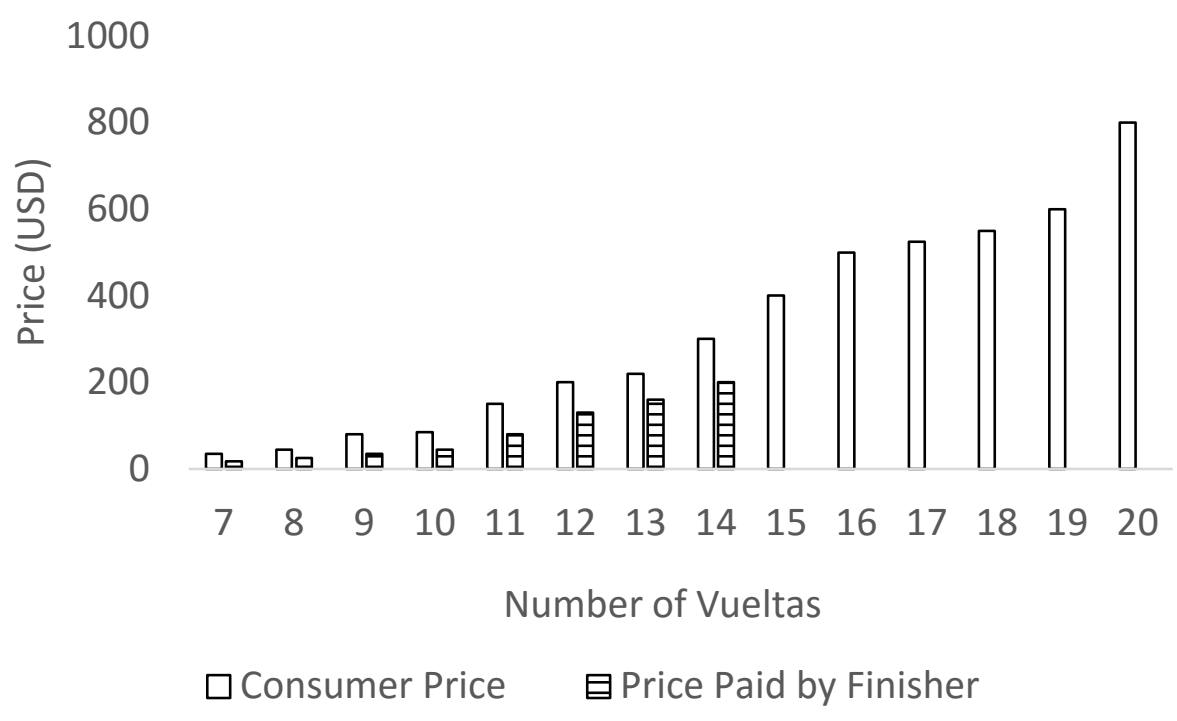

Figure 27. Price Paid by Consumers and by a Sombrero Finisher at Atlapa Convention Center, Panama City, in July 2016.

\section{CHAPTER 5: DISCUSSION}

The results are drawn from a limited number of interviews. Only thirty-three interviews took place between both districts. I attempted to interview a wide array of artisans, from those who wove rustic hats to those who wove high-end hats, but I achieved only a small sample. Since interviewees were chosen by word of mouth and through my limited connections in Panama, it is likely that this data is biased. Since I talked only with those weavers who were well-known within the communities, this left out the countless other weavers who existed within both districts. For this reason, I cannot consider my discussion or conclusions as providing definitive answers, but rather as a rough guide to the current status of sombrero weaving in Panama.

\section{The Availability of Fiber in Relation to the Hat Market}

Individual weavers were somewhat limited by availability of $C$. palmata in both La Pintada and Capira. Weavers in both districts said that they could find C. palmata when 
they needed it, but very few weavers reported having a consistent supply of their own $C$. palmata fiber without needing to purchase it. Similarly, Astrocaryum standleyanum was not found in abundance around higher-population areas in La Pintada. Weavers said that they needed to get this material from farther away in the hillside. It was not possible to quantify availability of this plant since it was outside the study area, but weavers said that supplies were sufficient to cover their needs. A. standleyanum was reported to exist in Capira, but since this plant was not used in this style of sombrero, weavers cared less about the existence of this material in their region.

While individual weavers talked about the prolonged dry season and increasing difficulty in accessing fiber, there was no talk of fiber scarcity within Panama as a whole. The issue may be, however, one that pertains to the quality of sombrero. For example, some weavers in La Pintada stated that they make five vuelta sombreros, but that the weavers from a different area of La Pintada make seven vuelta sombreros because they have access to more fiber in that location. It was not asked whether weavers would create finer sombreros if they had access to more fiber, but that may be helpful to know for future programs that promote the cultivation of fiber.

In Mexico, the major sources of C. palmata were plantations and private gardens in the states of Campeche and Yucatán (Fadiman 2001). In Santa Cruz, Mexico, most $C$. palmata fields were about $400 \mathrm{~m}^{2}$ and were family owned, but there were five cooperatives that cultivated larger areas of land (Fadiman 2001). Some C. palmata also grew in the community of Becal, Mexico but the water table was too far below the surface to support large plantations (Fadiman 2001). People may harvest leaves from uncultivated plants, but this fiber was considered inferior to cultivated plants (Fadiman 2001). 


\section{Improved Management of Fiber and Its Benefits to Weavers and}

\section{Processors}

While it takes special skill and patience to weave a sombrero, cultivation of C. palmata requires the same amount of work as other agronomic crops. By using a model farmer from La Pintada as an example of a mid-level cultivator, his business model shows us that cultivation and sale of $C$. palmata can be much more profitable than weaving and selling sombreros. If we consider the average of 1500 leaves cut per month, and take the price he charges for unprocessed leaf at about fourteen cents each, he stands to make $\$ 214$ per month simply by harvesting and selling leaves. Since he plants $C$. palmata into his farm, between stands of coffee and citrus, we can assume that the farm is yielding much more than just the profits from his fiber. He has additional cash crops as well as subsistence crops such as yuca that he grows. C. palmata from the nursery is sold for one to two dollars per plant.

Weavers cited increased scarcity of $C$. palmata more often in La Pintada than in Capira, and there were people taking measures to promote and conserve this plant in La Pintada. This was done through planting seeds in nurseries and transplanting C. palmata into the farm. Other cultivators managed naturally-occurring plants by transplanting them into desired areas. Processors in Capira did not mention doing any of this, and instead reported that they managed naturally-occurring stands that were found on their property.

It was demonstrated in La Pintada that simple management techniques can improve production of C. palmata fiber greatly. First, naturally-occurring young plants can be transplanted to areas that are more suited to their survival. Areas with better soil and additional shade from overstory plants can improve the microhabitat so that the plant can withstand the dry season more easily. The next level of management may include propagating additional plants by planting the seeds that are produced each year. These small seeds may be started in a nursery and then set out when they have reached a certain level of maturity. According to Gallegos (2004), growers in the Manabí province of Ecuador transplant C. palmata when it is six months old and it reaches sexual maturity 
one year later. C. palmata growers in Mexico burn the plots to clear weeds and then plant rhizomes collected from local plants (Fadiman 2001). The planters weed the fields every few weeks during the first year after planting until the adult plants create enough shade to deter weed growth (Fadiman 2001). Farmers in Mexico rarely use fertilizer, since the soil remains fertile enough to support populations for extended periods, and insecticide is used only when there is an insect plague (Fadiman 2001).

To further enhance survival and production of leaves, an irrigation system may be implemented. In Mexico, the best quality fiber requires about ten liters of water per plant daily, and cultivators often use irrigation to achieve this requirement (Fadiman 2001). In Panama, irrigation may not only improve leaf production but also fiber quality. This would be of particular importance to high-end weavers who seek only the best fiber for their work. Irrigation, however, is site specific and it relies on the amount of water that is available to a community. Nevertheless, it has been demonstrated that production can be improved even without irrigation. This may be accomplished by intercropping $C$. palmata with other species, such as coffee or citrus. The extra shade helps conserve soil moisture, and since C. palmata is reported to be found more in edge areas (Richards 1975), this way of planting mimics its natural state in the wild.

A few techniques also may be used in order to harvest the fibers without killing the plants. For example, in Ecuador only about half the leaves in each colony are harvested to maintain a sustainable crop (Gallegos and Burbano 2004). In Mexico, each plant produces a usable leaf every fifteen days, which is harvested using a small machete and only the inner leaf is removed, thus keeping the plant alive (Fadiman 2001). Harvesting shoots before the first flowering can have a negative effect on the plant population. In Ecuador, young leaves are harvested when the plants are two-and-a-half-year-old, after they have had one reproductive cycle (Gallegos and Burbano 2004). Once the plants are mature, regular harvest (e.g., every 15-20 days) has been found to stimulate height growth and production of shoots and plantlets, as well as maintain thinner, finer shoot venation (Gallegos and Burbano 2004). In some regions this is done only during a full 
moon, because harvests during other times are believed to dry out the plant so it will not produce more leaves (Chízmar 2009).

\section{Variation in fiber and sombrero pricing by time, district, gender, age, and buyer}

Sombrero prices in Panama have seen an increase over the past nine years (2007-2016). Prices from the Atlapa Convention Center for July 2016 were double that of prices cited by Fernandez (2007) for the year 2007 (Table 13). For example, a sixteen vuelta Sombrero Pintado sold for \$240 in 2007 (Fernandez 2007), while in 2016 it was selling for $\$ 500$. The biggest change, however, was with the seven vuelta sombrero. This went from twelve dollars in 2007 (Fernandez 2007) to \$35 in 2016. Weavers cite the Sombrero Pintado Festival as being a primary reason for the price increase.

The Sombrero Pintado Festival began in 2011 in La Pintada as a way to recognize weavers and honor the culture of the district. This festival features parades, music, food, and sombrero vendors from the area. The event was created as a way to add cultural significance and value to sombreros from this region. Each year there are competitions for the best sombrero in different vuelta classes. Winners in these categories receive a substantial monetary prize and their name becomes better known. Weavers report that sombrero prices for high-end hats have doubled since the inception of this event. Weavers who participate increase their client list because their artisanry becomes betterknown throughout the nation.

The district of La Pintada has better infrastructure and better access to larger markets than does Capira. This is evident through the quality of paved roads, the use of cement in homes, the presence of reliable and comfortable transportation in the form of small buses, access to electricity, and cell-phone coverage. The Ministry of Industry and Commerce also has been helping to promote economic activities with artisan work within this district. Paved roads, electricity, and cell-phone coverage are quite good in some areas of Capira, but these communities have less-frequent transportation and passengers still must 
ride in the back of a small truck. The communities of Capira, in general, have fewer amenities and are more difficult to reach than many of the communities of La Pintada.

For having better infrastructure and more presence of government help, La Pintada does not appear to provide a better wage for all weavers across the board. It is true that highend weavers can earn a considerable amount for their work, but it is likely that they represent a small minority of weavers. In general, prices received by artisans in $\mathrm{La}$ Pintada are not better than what weavers in Capira receive. In fact, the majority of female weavers are earning less than $1 / 10$ of what male weavers in Capira earn per sombrero. This means that a man in Capira can weave an $\$ 80$ sombrero in about a week, while a woman in La Pintada can expect six or seven dollars for a sombrero that she will make during the same amount of time.

Perhaps there are some differences between Capira and La Pintada that account for this price difference. First, low-end sombreros are very plentiful around La Pintada. The majority of women interviewed specialize in either a five or a seven vuelta sombrero. If these women were able to devote more time to producing higher-quality sombreros, there is a chance that they could earn more money. This is probably not feasible, however, since most women across Panama are required to cook, clean, take care of children, and run the household. Any time that women take to weave is free time when they are not needed for anything else. On the other hand, if the men are not working or in the field, they are generally not expected to do much around the house apart from general maintenance or building projects. It is for this reason that men can devote more of their time to weaving.

Although women in Capira were not reported to weave much for an income, they typically weave for family members and not usually for sales. Since most women that were encountered in Capira do not engage in market activity, it was difficult to quantify their work. Some demonstrated very fine sombreros that they had woven, but they were made as gifts rather than for profit. 
Female weavers in Capira were few in number, and they were more prone to weave with junco. These hats are rustic when compared to ones made from C. palmata, but they stand up better for daily work. It is more taxing to weave with Cyperus spp. (junco), since the fiber is sharp, and is more prone to cut the hands of the weaver. When women were found who wove with junco instead of $C$. palmata, their information was not included with this study. This is because this study focuses on those weavers who use C. palmata as the main source for the sombrero. No men were found to weave with junco.

In some instances in La Pintada and Capira husbands and wives worked together on the same sombrero in order to get it finished more quickly. This was more prevalent with high-end sombreros in La Pintada, but it also was reported in one case in Capira. In these cases it was difficult to talk to the wife, since the husband did most of the talking for both. For this reason, answers were provided by the husband, but not the wife.

In La Pintada, a group of female weavers was started by a teacher from a local school in 1989, and the group was strengthened with the help of a Peace Corps volunteer from 1990 to 1991. The group began with 80 members, and today seven remain. Each member had her own plot of $C$. palmata that she harvested. The group functioned as a way for women to weave together once a week, and they took turns managing the funds that were earned by the group. The group fund was used to purchase sombreros from each member, and then those sombreros were sold by the group to an intermediary. From the group fund, seven dollars was paid for each sombrero, and the intermediary paid $\$ 7.50$. The extra fifty cents from each sombrero sale remained in the fund and was paid back to each member at the end of the year as a bonus. So, if a member sold 20 hats in a year, she would get a ten-dollar bonus at the end of the year.

The group functioned as a way for women to save more of their money, but also it functioned to combat machismo culture in rural Panama. Group members said that the Peace Corps volunteer helped introduce them to such ideas as woman empowerment through various workshops. Group members expressed that their husbands were more 
respectful to them than they had been in the past, and that husbands were more likely to help around the house. In this sense, weaving is not all about making a profit, but can provide a social outlet and a sense of empowerment for people, especially women. Encouraging more of these weaving groups of women may help to improve the disparity between male and female sombrero pricing.

Today, Peace Corps is still working with artisan groups within Panama. A Peace Corps volunteer within La Pintada has been working with an artisan group in an effort to increase profits. It is difficult to quantify the time involved with weaving a sombrero since it depends on many factors, but the group decided that it takes about 25 hours to weave a five vuelta sombrero, not including the time it takes to harvest and process the fiber (Table 3). Since the goal of the group was to earn one dollar per hour for their work, they began marketing their five vuelta sombreros for $\$ 25$ apiece to foreign visitors. This was successful since the community gets waves of volunteer aid workers on occasion. Although this manner of selling does not provide a continuous market, it is a way for artisans to see the possibility of a more equitable sombrero market. To keep with the dollar per hour wage, a six vuelta is priced at $\$ 30$ up to an eight vuelta that is sold for $\$ 45$. Artisans reported that foreigners prefer to buy more rustic hats and that they are not interested in buying high-end sombreros. 
Table 3. Pricing of Somberos by Artisan Group

in Las Delicias, La Pintada, Coclé, Panama.

\begin{tabular}{ccc}
\hline $\begin{array}{c}\text { No. of } \\
\text { Vueltas }\end{array}$ & $\begin{array}{c}\text { No. of } \\
\text { Hours }\end{array}$ & $\begin{array}{c}\text { Price } \\
(\$)\end{array}$ \\
\hline 5 & 25 & 25 \\
6 & 30 & 30 \\
7 & 35 & 35 \\
8 & 45 & 45 \\
\hline
\end{tabular}

Sombrero clients also are worthy of consideration. Whether sombreros are bought by intermediaries or by a direct customer, this person is almost always male. All of the intermediaries that were encountered were men, and because the sombrero is a male accessory it is usually bought by a man. While women in La Pintada voiced their frustration with how little intermediaries paid, male weavers in Capira were content with what intermediaries paid and were happy to have the business. When men spoke of lowering their price for an intermediary, they spoke with understanding and said that they were still quite happy with the price. The difference in Capira was that even with lowering the price for an intermediary, the weaver was still making a decent profit on his work.

Sombreros from La Pintada were often sold on the hat market for about twice what was paid to the weaver. For example, a seven vuelta sombrero was reportedly sold to an intermediary for \$15, and an eight vuelta for \$25. At the 2016 Atlapa Artisan Fair in Panama City, a seven vuelta was sold for $\$ 35-40$ and an eight vuelta for $\$ 45$. That is about twenty dollars per sombrero that weavers are losing by selling to an intermediary. It would be difficult to expect low-scale weavers to have enough capital or product to sell on the national market, but weavers might still be able to improve profits while working within the current system. This could be achieved by weaving higher-quality hats. For example, an eight vuelta sombrero takes an average of 45 hours to complete, and it sells 
to intermediaries for around $\$ 25$. By switching from a five-vuelta to an eight-vuelta, a weaver could almost double their earnings (Table 4).

Table 4. Potential Earnings from a Five Vuelta Sombrero Compared to an Eight Vuelta Sombrero in La Pintada.

\begin{tabular}{llll}
\hline Vueltas & Price (USD) & Hours & $\begin{array}{l}\text { Price per } \\
\text { hour }\end{array}$ \\
\hline 5 & 7 & 25 & .28 \\
\hline 8 & 25 & 45 & .55 \\
\hline
\end{tabular}

In general, sombreros in Capira were sold directly from weaver to client, or they may have passed through an intermediary. Weavers in Capira stated that they would not weave if they did not have a client or if they could not be assured of getting a fair price for their work. This contrasts with many of the weavers in La Pintada, who said they weaved because it was part of their tradition. Female weavers in La Pintada said often that they weaved whether or not they had a client in mind, and would sell the sombrero however they could. This resulted often in selling for a very low price.

Some men in in Capira stated that they would like to weave full-time, but that market limitations prevented them from doing so. Low prices were one reason for not weaving full-time. Other weavers in the district weaved more consistently, either for direct clients or to sell to an intermediary. Those who wove more frequently reported that they were content with the prices that they had earned from their work and that they could usually find a customer to purchase sombreros.

\section{Artisan culture and government outreach}

Artisan work can contribute greatly to the income of a family. This is especially important in rural Panama where few economic opportunities exist. High-end weavers 
reported that they bought the majority of their fiber instead of processing it themselves. This seems reasonable given that they were making a large profit from their work. Lowend weavers, however, reported also that they needed to purchase fiber at times. It was almost a given that $A$. standleyanum would be purchased, since this plant was said to exist only farther in the hillside. When C. palmata was purchased in addition to $A$. standleyanum, a hat brought almost no net income for a low-end weaver.

Although there was no record of government outreach in supporting artisans in Capira, all classes of weavers could potentially earn a modest income (Table 5). It is possible that government outreach in La Pintada has benefitted high-end weavers. Monthly incomes for these weavers was considerably higher than wages of lower-end weavers (Table 6). 
Table 5. Estimated Monthly Income of Three Classes of Weavers in Capira District, Panama Oeste, Panama.

\begin{tabular}{llllll}
\hline $\begin{array}{l}\text { Class } \\
\text { of } \\
\text { Weaver }\end{array}$ & $\begin{array}{l}\text { \# Hats } \\
\text { month }\end{array}$ & $\begin{array}{l}\text { Price } \\
\text { per hat } \\
(\$)\end{array}$ & $\begin{array}{l}\text { Avg. } \\
\text { Investment } \\
\text { per hat } \\
\text { (bellota } \\
\text { and yarn) }\end{array}$ & $\begin{array}{l}\text { Monthly } \\
\text { Income }\end{array}$ & $\begin{array}{l}\text { Monthly } \\
\text { bellota is } \\
\text { grown } \\
\text { and } \\
\text { processed } \\
\text { by the } \\
\text { weaver }\end{array}$ \\
\hline Low & 3 & 80.00 & 9.00 & 213.00 & 231.00 \\
Middle & 3 & 100.00 & 10.50 & 268.50 & 291.00 \\
High & 3 & 120.00 & 12.00 & 324.00 & 351.00 \\
\hline
\end{tabular}

Table 6. Estimated Monthly Income of Two Classes of Weavers in La Pintada District, Coclé, Panama.

\begin{tabular}{llllll}
\hline $\begin{array}{l}\text { Class } \\
\text { of }\end{array}$ & $\begin{array}{l}\text { \# Hats } \\
\text { per }\end{array}$ & $\begin{array}{l}\text { Price } \\
\text { per hat her } \\
(\$)\end{array}$ & $\begin{array}{l}\text { Avg. } \\
\text { Investment } \\
\text { (bellota } \\
\text { and } \\
\text { chonta) }\end{array}$ & $\begin{array}{l}\text { Monthly } \\
\text { Income }\end{array}$ & $\begin{array}{l}\text { Monthly } \\
\text { Income if } \\
\text { bellota is } \\
\text { grown } \\
\text { and } \\
\text { processed } \\
\text { by the } \\
\text { weaver }\end{array}$ \\
\hline $\begin{array}{l}\text { Low } \\
\text { End }\end{array}$ & 4 & 6.00 & 4.00 & 8.00 & 16.00 \\
$\begin{array}{l}\text { High } \\
\text { End }\end{array}$ & 1 & 800.00 & 35.00 & 765.00 & 795.00 \\
\hline
\end{tabular}

Continued government outreach that promotes improved fiber production would be beneficial. Past attempts of promoting cultivation have had modest success. Factors such as soil type and access to irrigation appear to determine plant survival more than other factors. Government support that provides education and access to irrigation supplies could help individual cultivators improve their stands of C. palmata. 
Like what has been done in Ecuador, the Panamanian government is working to get the Sombrero Pintado recognized for its cultural heritage through the United Nations Educational, Scientific and Cultural Organization (UNESCO) (Grimaldo 2016). Weavers in Montecristi, Ecuador, already have intellectual property rights to their style of hat (Russell 2010). Known now as the montecristi, this straw hat was recognized as the first registered geographical indication (GI) in Ecuador in 2008 (Russell 2010). Weavers began working for this geographical indication in 2005 when a cooperative of C. palmata artisans filed a petition for GI registration with the Ecuadorian Institute of Intellectual Property (IEPI) (Russell 2010). To support its claim, the cooperative alleged that its design of hat was known on the international market as the montecristi (Russell 2010). Furthermore, the cooperative claimed that their community of Montecristi was responsible for the respected reputation of the hats produced around Manabí province since 1630, as well as for the development of the montecristi name around the world.

To be eligible for GI status, the IEPI decided that human and natural factors had created a superior material and process for hat-making that was distinct to the area surrounding Montecristi (Russel 2010). For example, the changing warm and humid climate contributed to the quality of the fibers. Temperatures there range between twelve and fifteen degrees Celsius during the winter and twenty and twenty-two degrees Celsius during the summer. In addition to the climate, C. palmata grows well in the fertile soil of Manabí that is rich in salt and limestone (Russell 2010). C. palmata of this region is noticeably superior to fiber from other regions. Furthermore, the IEPI emphasized the importance of human factors by noting that locals have passed down their techniques since 1630 (Russell 2010). Although there is a longer history of hat making in Ecuador, Panama has a very similar tradition of hat making and could benefit from receiving special status for the Sombrero Pintado. 


\section{CHAPTER 6: CONCLUSIONS AND RECOMMENDATIONS}

- The sombrero market in Panama did not appear to be restricted by the availability of A. standleyanum or C. palmata at this time. Individual weavers, however, may have been restricted by the amount of fiber that they could access or purchase for themselves.

- La Pintada had better infrastructure, a stronger artisan culture, and more government assistance than did Capira. High-end artisans in La Pintada appeared to earn a very good income for their work. Low-end artisans in La Pintada, however, did not earn very much for their labor. Artisans in Capira were more middle-of-the road, in that they earned a decent income but not nearly what highend weavers in La Pintada earned.

- Overall, fiber was costlier in Capira. Sombrero prices in Capira were more uniform, while sombrero prices in La Pintada had a greater variability. Sombrero prices did not appear to differ by the age of the weaver, but prices did differ between genders. Overall, men reported earning more from sombrero sales than did women. Direct sales of sombreros (from weaver to client) usually resulted in the best price. It was shown, however, that an intermediary could sometimes offer a better price than what could be paid within the community of the weaver. Sombrero prices appeared to have increased over the past ten years. This could be simply a reflection of rising wages, but it may also be associated with government programs that have worked to increase the value of the Sombrero Pintado.

- Irrigation could be beneficial to improve management of $C$. palmata. Since cultivators stated that the prolonged dry season had killed off plantings, irrigation might sustain plantings when there is not enough rain. Furthermore, irrigation may increase fiber quality, as is reported in Mexico. Companion planting of $C$. palmata between other overstory species, such as coffee and citrus, may be able to maintain soil moisture longer with increased shade. 
- Although women typically had less time to devote to weaving, some management techniques and price bargaining could be implemented through strengthened artisan groups. A group can build solidarity among women while also providing additional capital and labor if the group decides to plant and manage fiber. 


\section{REFERENCES}

Baijnath, H. (1975). "A Study of Cyperus alternifolius L., sens. lat. (Cyperaceae)." Kew Bulletin. 30(3): 521-526.

Bank, T. W. (2016). "Panama." Retrieved October 25, 2016, from http://www.worldbank.org/en/country/panama.

Bennett, B. C., R. Alarcón, and C. Cerón (1992). "The ethnobotany of Carludovica palmata Ruíz \& Pavón (Cyclanthaceae) in Amazonian Ecuador." Economic Botany. 46(3): 233-240.

Bernard, H. R. (1995). Research Methods in Anthropology: Qualitative and Quantitative Approaches. Oxford, England. AltaMira Press.

Bristol, M. L. (1961). "Carludovica palmata in Broommaking." Botanical Museum Leaflets Harvard Univesity. 19(9).

Chízmar, C., Allys Lu, Mireya Correa (2009). Plantas de uso folclórico y tradicional en Panamá. Santo Domingo de Heredia, Costa Rica Instituto Nacional de Biodiversidad, INBio.

Dalet, D. (2016). Map of Panama. Political Map. D-map.com.

Economist, T. (2014, July 19). "Hold on to your headwear: Ecuador makes them and wants you to know it." Retrieved October 25, 2016, from http://www.economist.com/news/americas/21607890-ecuador-makes-them-and-wantsyou-know-it-hold-your-headwear.

Espinosa, J. C. (1998). "Elementos para la conservación y manejo de Carludovica palmata en Centroamerica." Centro Agronomico Tropical de Investigacion y Ensenanza Programa de Ensenanza para el Desarrollo y la Conservacion Escuela de Postgrado.

Fadiman, M. (2001). "Hat weaving with Jipi, Carludovica palmata (Cyclanthaceae) in the Yucatan Peninsula, Mexico." Economic Botany. 55(4): 539-544. 
Fernandez, R. R. (2007). El Sombrero Artesanal En la Economia y Cultura del Distrito de La Pintada. History. Panama City, Panama. University of Panama. MS History.

Gallegos, R. A. and M. F. Burbano (2004). "Use of Paja Toquilla (Carludovica palmata Ruiz \& Pavon) For the Production of Panama Hats in Three Communities of Manabi Province, Ecuador." Estudios de Caso sobre Sistemas de Manejo de Productos Forestales No Maderables.

Gentry, A. H. (1992). "Annals of the Missouri Botanical Garden." Missouri Botanical Garden Press. 79(1): 53-64.

Grimaldo, M. (2016, 30 March ). "Representative List of the Intangible Cultural Heritage of Humanity." Retrieved October 25, 2016, from www.unesco.org/culture/ich/doc/download.php?versionID=42403.

Kirby, R. H. (1963). Vegetable Fibres: Botany, Cultivation, and Utilization. New York Interscience Publishers, Inc.

Lasso, R. (2013). Salvaguarda Del Sombrero Pintao de Panama. Anthropology. Santiago, Republic of Chile University Alberto Hurtado.

Lincoln, K. and Blair Orr. (2011). "The Use and Cultural Significance of the Pita Plant (Aechmea magdalenae) among Ngobe Women of Chalite, Panama." Economic Botany. 65(1).

Mabberley, D. J. (1987). The plant-book: a portable dictionary of the higher plants. Cambridge University Press.

Martinez, P. L. (1980). Breve reseña acerca de la confeccion del Sombrero Pintado de las comunidades de La Honda, Membrillar y La Venta. Distrito de La Pintada, Provincia de Cocle. Agronomy. Panama City. University of Panama. Home Education.

Meditz, S. W. and D. M. Hanratty (1989). Panama: a country study. Federal Research Division Library of Congress.

Pedersen, B. (1994). "Mocora Palm-Fibers: Use and Management of Astrocaryum standleyanum (Arecaceae) in Ecuador" Economic Botany. 48(3): 310-325. 
Potvin, C. et al. (2001). "Preparation for propagation: understanding germination of giwa (Astrocaryum standleyanum), wagara (Sabal mauritiiformis) and eva (Socratea exorrhiza) for future cultivation." Kluwer Academic Publishers.

Purseglove, J. W. (1972). Tropical Crops: Monocotyledons. New York Longman, Inc. .

Richards, P. and G. B. W. (1975). "Treefalls and Patterns of Understory Species in a Wet Lowland Tropical Forest." Ecology. 56(5): 1226-1229.

Runk, J. V. (2001). "Wounaan and Embera Use and Management of the Fiber Palm Astrocaryum standleyanum (Arecaceae) for Basketry in Eastern Panama." Economic Botany. 55(1 72-82).

Russell, A. B. (2010). "Using Geographical Indicators to Protect Artisanal Works in Developing Countries: Lessons from a Banana Republic's Misnomered Hat."

SINAMP (2006). "Estimacion de la poblacion en la provincia de Cocle, Por Sexo, Segun Distritio y Corregimiento." From http://www.contraloria.gob.pa/inec/sinamp/pdf/cocle.pdf.

Smythe, N. (1989). "Seed Survival in the Palm Astrocaryum standleyanum: Evidence for Dependence upon its Seed Dispersers." Biotropica. 21(1): 50-56.

Social, M. d. D. (2016). "MIDES." Retrieved October 23, 2016, from http://www.mides.gob.pa/.

Tucker, G. C. (1983). "The Taxonomy of Cyperus (Cyperaceae) in Costa Rica and Panama." Systematic Botany Monographs. 2: 1-85.

Vickers, W. T. and T. P. (1984). "Useful Plants of the Siona and Secoya Indians of Eastern Ecuador." Botany New Series. 15.

Weil, T. E. et al. (1972). Area Handbook for Panama. Washington, D.C. U.S. Government Printing Office. 
Wilder, G. J. (1976). "Structure and Development of Leaves in Carludovica palmata (Cyclanthaceae) with Reference to Other Cyclanthaceae and Palmae. " American Journal of Botany. 63(9): 1237-1256.

Zuchowski, W. (2007). Tropical Plants of Costa Rica. Cornel, New York Zona Tropical. 


\section{TABLES AND FIGURES}

Table 7. Average number of $C$. palmata leaves harvested each month by fiber processors in the district of La Pintada, Coclé, Panama.

\begin{tabular}{|c|c|c|}
\hline District & $\begin{array}{c}\text { Average } \\
\text { No. of } \\
\text { Leaves } \\
\text { Harvested } \\
\text { per month }\end{array}$ & $\begin{array}{l}\text { No. of } \\
\text { Plants }\end{array}$ \\
\hline $\begin{array}{c}\text { La } \\
\text { Pintada }\end{array}$ & 60 & - \\
\hline $\begin{array}{c}\text { La } \\
\text { Pintada }\end{array}$ & 1500 & 500 \\
\hline $\begin{array}{c}\text { La } \\
\text { Pintada }\end{array}$ & 60 & - \\
\hline $\begin{array}{c}\text { La } \\
\text { Pintada }\end{array}$ & 100 & 50 \\
\hline $\begin{array}{c}\text { La } \\
\text { Pintada }\end{array}$ & 240 & 80 \\
\hline $\begin{array}{c}\text { La } \\
\text { Pintada }\end{array}$ & 100 & - \\
\hline
\end{tabular}


Table 8. Price Per Processed Leaf of C. palmata in the District of Capira

\begin{tabular}{|c|c|c|}
\hline Code \# & Community & $\begin{array}{c}C . \\
\text { palmata } \\
\text { Price Per } \\
\text { Processed } \\
\text { Leaf } \\
\text { (USD) }\end{array}$ \\
\hline 1 & Las Claras & 0.2 \\
\hline 2 & Las Claras & 0.25 \\
\hline 3 & Las Claras & 0.27 \\
\hline 4 & Las Claras & 0.2 \\
\hline 6 & Las Claras & 0.25 \\
\hline 7 & Las Claras & 0.27 \\
\hline 8 & Las Claras & 0.1 \\
\hline 10 & Las Claras & 0.5 \\
\hline 21 & Las Claras & 0.25 \\
\hline 16 & La Bonga & 0.5 \\
\hline 17 & La Bonga & 0.5 \\
\hline 18 & La Bonga & 0.75 \\
\hline 19 & La Bonga & 0.5 \\
\hline 20 & La Bonga & 0.5 \\
\hline 28 & La Bonga & 0.6 \\
\hline 32 & La Bonga & 0.5 \\
\hline 33 & La Bonga & 0.5 \\
\hline
\end{tabular}


Table 9. Price Per Processed Leaf of C. palmata in the District of La Pintada

\begin{tabular}{|c|c|c|}
\hline Code \# & Community & $\begin{array}{l}\text { C. palmata } \\
\text { Price Per } \\
\text { Processed } \\
\text { Leaf (USD) }\end{array}$ \\
\hline 12 & $\begin{array}{l}\text { Piedras } \\
\text { Gordas }\end{array}$ & 0.5 \\
\hline 13 & $\begin{array}{l}\text { Piedras } \\
\text { Gordas }\end{array}$ & 0.17 \\
\hline 14 & $\begin{array}{l}\text { Piedras } \\
\text { Gordas }\end{array}$ & 0.17 \\
\hline 15 & $\begin{array}{l}\text { Piedras } \\
\text { Gordas }\end{array}$ & 0.17 \\
\hline 22 & El Guabo & 0.17 \\
\hline 23 & Machuca & 0.25 \\
\hline 24 & Machuca & 0.17 \\
\hline 25 & $\begin{array}{l}\text { Las } \\
\text { Delicias }\end{array}$ & 0.14 \\
\hline 26 & $\begin{array}{l}\text { Las } \\
\text { Delicias }\end{array}$ & 0.14 \\
\hline 29 & Pedregoso & 0.33 \\
\hline 30 & Pedregoso & 0.25 \\
\hline
\end{tabular}


Table 10. Sombrero Prices in the Community of La Bonga Abajo, Capira, Panama. *Has never made a 26 vuelta sombrero, but says that he would charge \$200 if someone asked him to make one

\begin{tabular}{|c|c|c|c|}
\hline Weaver \# & No. of Vueltas & $\begin{array}{c}\text { Price if } \\
\text { sold in } \\
\text { community } \\
\text { (USD) }\end{array}$ & $\begin{array}{l}\text { Price if sold } \\
\text { outside } \\
\text { community } \\
\text { (USD) }\end{array}$ \\
\hline 32 & 18 & 90 & - \\
\hline 32 & 22 & 130 & - \\
\hline 32 & 23 & 150 & - \\
\hline 32 & 24 & 180 & - \\
\hline \multirow[t]{2}{*}{18} & 21 & 100 & 120 \\
\hline & 21 vuelta sombrero & & \\
\hline 18 & pintado & - & 150 \\
\hline 18 & 22 & 100 & \\
\hline 18 & 23 & 100 & 150 \\
\hline \multirow[t]{2}{*}{18} & 24 & 100 & 150 \\
\hline & $26^{*}$ & - & 200 \\
\hline
\end{tabular}


Table 11. Consumer Prices of Sombrero Pintados at Atlapa Convention Center, Panama City, Panama, July 2016

\begin{tabular}{cc}
\hline \#Vueltas & Price (USD) \\
\hline 7 & $35-40$ \\
8 & 45 \\
9 & 80 \\
10 & $85-90$ \\
11 & 150 \\
12 & 200 \\
13 & 220 \\
14 & $280-300$ \\
15 & 400 \\
16 & 500 \\
17 & $500-550$ \\
18 & 550 \\
19 & 600 \\
20 & 800 and up \\
\hline
\end{tabular}


Table 12. Price Paid for Sombreros by a Sombrero Finisher. July 2016

\begin{tabular}{cc}
\hline \#Vueltas & $\begin{array}{c}\text { Price } \\
\text { (USD) }\end{array}$ \\
\hline 7 & $16-18$ \\
8 & 25 \\
9 & $35-40$ \\
10 & $45-50$ \\
11 & $75-80$ \\
12 & $120-$ \\
& 130 \\
13 & $150-$ \\
& 160 \\
14 & 200 \\
\hline
\end{tabular}


Table 13. Sombrero Prices from 2007 and from ten years before 2007 (Fernandez 2007).

\begin{tabular}{|c|c|c|c|c|c|c|}
\hline \multirow[t]{2}{*}{$\begin{array}{l}\text { No. of } \\
\text { Vueltas }\end{array}$} & $\begin{array}{l}\text { Price } \\
\text { from }\end{array}$ & $\begin{array}{l}\text { Price } \\
\text { from }\end{array}$ & $\begin{array}{l}\text { Days of } \\
\text { work }\end{array}$ & \multicolumn{2}{|c|}{$\begin{array}{c}\text { Price paid to } \\
\text { weaver (USD) }\end{array}$} & \multirow{2}{*}{$\begin{array}{l}\text { Consumer } \\
\text { price } \\
\text { (USD) }\end{array}$} \\
\hline & $\begin{array}{l}1997 \\
\text { (USD) }\end{array}$ & (USD) & $\begin{array}{l}\text { to weave } \\
\text { sombrero }\end{array}$ & & & \\
\hline 5 & $\$ 2$ & 6 & N/A & Dry & Wet & \\
\hline & & & & $\underline{\text { Season }}$ & $\underline{\text { Season }}$ & \\
\hline 6 & 4 & 8 & $\mathrm{~N} / \mathrm{A}$ & & & \\
\hline 7 & 5 & 12 & 8 & 7 & 4 & 12 \\
\hline 8 & 10 & 25 & 9 & 8 & 6 & 25 \\
\hline 9 & 15 & 35 & 10 & 15 & 12 & 35 \\
\hline 10 & 20 & 45 & 15 & 23 & 13 & 45 \\
\hline 11 & 30 & 60 & 15 & 28 & 20 & 60 \\
\hline 12 & 45 & 80 & 20 & 40 & 35 & 80 \\
\hline 13 & 65 & 110 & 25 & 50 & 40 & 100 \\
\hline 14 & 110 & 150 & 30 & 60 & 50 & 150 \\
\hline 15 & 120 & 200 & 40 & 80 & 60 & 200 \\
\hline 16 & 180 & 240 & 40 & 95 & 70 & 240 \\
\hline 17 & 200 & 260 & $\mathrm{~N} / \mathrm{A}$ & & & \\
\hline 18 & 270 & 300 & N/A & & & \\
\hline
\end{tabular}




\begin{tabular}{|c|c|c|c|c|c|c|c|c|c|c|c|}
\hline & 莺 岛 & I & 0 & 0 & $\stackrel{d}{d}$ & ' & $\stackrel{\infty}{+\infty}$ & ' & $\stackrel{d}{d}$ & $\stackrel{\infty}{+\infty}$ & $\simeq$ \\
\hline & 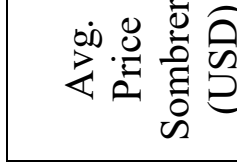 & 0 & ' & ' & $\simeq$ & r & $\stackrel{n}{n}$ & r & $\simeq$ & r & 8 \\
\hline & $\frac{0}{a}$ & 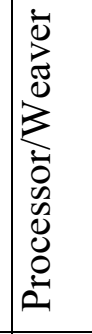 & 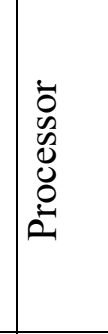 & 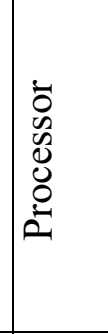 & 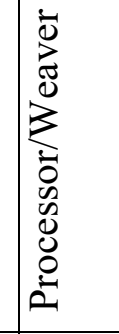 & 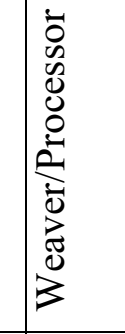 & 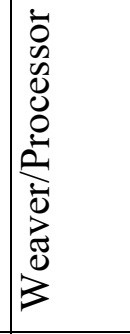 & 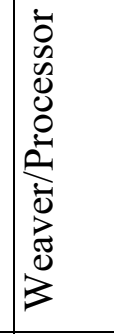 & 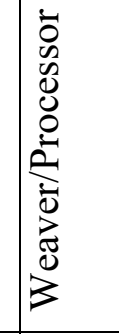 & 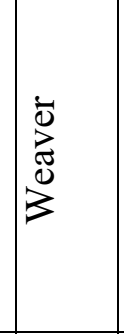 & 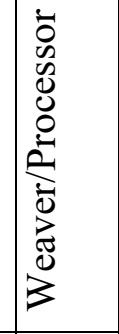 \\
\hline & 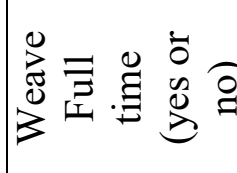 & 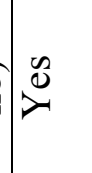 & $\stackrel{8}{z}$ & $\not 2$ & $\stackrel{\circ}{z}$ & 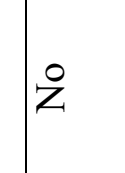 & $D_{0}^{\infty}$ & 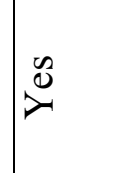 & $\underbrace{\infty}_{0}$ & 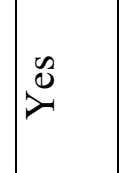 & 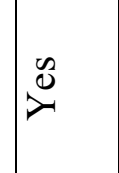 \\
\hline & 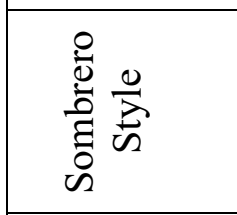 & 遏 & ' & I & 遭 & 惫 & $\begin{array}{l}\text { 递 } \\
\text { 鄫 }\end{array}$ & 遏 & 苟 & 曾 & 苟 \\
\hline & 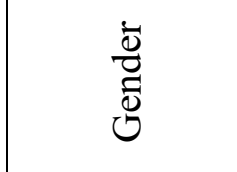 & $I$ & $\Sigma$ & $\Sigma$ & $I$ & $\Psi$ & II & 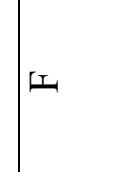 & $\Phi$ & II & I \\
\hline & $\begin{array}{l}s_{0}^{\infty} \\
\frac{8}{4} \\
\end{array}$ & $\begin{array}{l}8 \\
0 \\
0 \\
9 \\
9\end{array}$ & $\begin{array}{l}8 \\
0 \\
1 \\
9 \\
9\end{array}$ & \begin{tabular}{l}
8 \\
0 \\
1 \\
\multirow{7}{*}{}
\end{tabular} & $\begin{array}{l}8 \\
0 \\
0 \\
9 \\
7\end{array}$ & 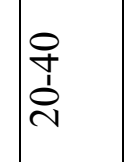 & $\begin{array}{l}0 \\
0 \\
0 \\
0 \\
0\end{array}$ & ơ & $\begin{array}{l}8 \\
0 \\
0 \\
9 \\
9\end{array}$ & 吕 & $\begin{array}{l}8 \\
0 \\
0 \\
9 \\
9\end{array}$ \\
\hline & 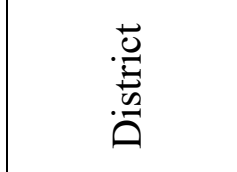 & 离 & 苞 & 苞 & 莺 & 苟 & 苞 & 宽 & 苟 & 苞 & 莺 \\
\hline & $\begin{array}{l}\text { 畕 } \\
\text { 音 } \\
\text { ठ }\end{array}$ & 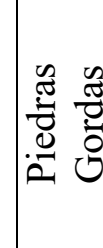 & 造 & 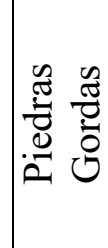 & 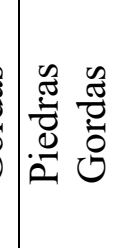 & $\int$ & 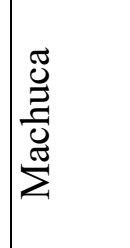 & 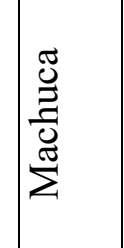 & 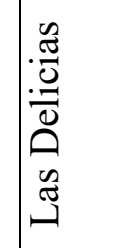 & 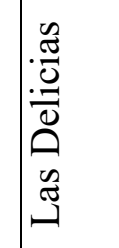 & 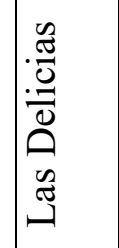 \\
\hline & $\frac{8}{8}$ & $=\approx$ & $\cong$ & $\Xi$ & $\cong$ & $\tilde{\pi}$ & $\tilde{\lambda}$ & $\stackrel{ \pm}{\sim}$ & $\Re$ & $\underset{\sim}{\infty}$ & $\bar{\wedge}$ \\
\hline
\end{tabular}




\begin{tabular}{|c|c|c|}
\hline ' & $\simeq$ & 0 \\
\hline 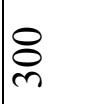 & 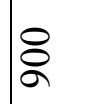 & $\stackrel{\infty}{\infty}$ \\
\hline 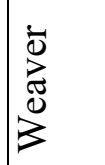 & 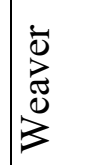 & 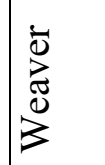 \\
\hline$\stackrel{\infty}{\infty}$ & $\stackrel{0}{\infty}$ & $\underset{\nu}{\infty}$ \\
\hline 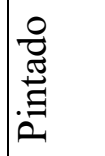 & 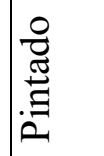 & 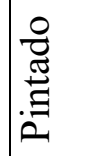 \\
\hline$\Sigma$ & $\Sigma$ & $\Sigma$ \\
\hline $\begin{array}{l}8 \\
8 \\
1 \\
1 \\
\dot{q}\end{array}$ & 宇 & $\begin{array}{l}8 \\
8 \\
1 \\
1 \\
+\end{array}$ \\
\hline 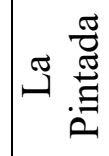 & 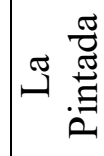 & (马) \\
\hline 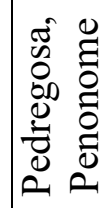 & 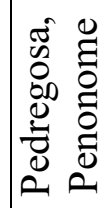 & 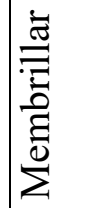 \\
\hline নे & in & $\bar{m}$ \\
\hline
\end{tabular}




\begin{tabular}{|c|c|c|c|c|c|c|c|c|c|}
\hline \multicolumn{2}{|r|}{ 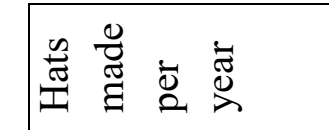 } & $\stackrel{\infty}{.}$ & 6 & in & A & $A^{4}$ & A & 6 & $\alpha$ \\
\hline & 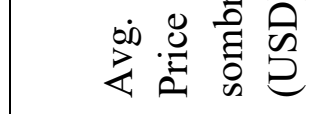 & $\infty$ & $\infty$ & in & $\infty$ & $\infty$ & $\infty$ & $\infty$ & $R$ \\
\hline & $\frac{0}{2}$ & 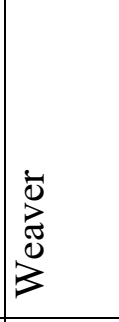 & $\begin{array}{l}\overline{0} \\
\bar{J} \\
3 \\
3\end{array}$ & 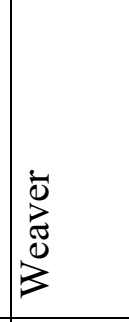 & $\begin{array}{l}\overline{0} \\
\bar{J} \\
3 \\
3\end{array}$ & 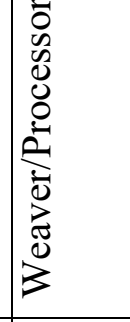 & $\begin{array}{l}\dot{\bar{D}} \\
\overline{\vec{d}} \\
\dot{3}\end{array}$ & $\begin{array}{l}\tilde{y} \\
\tilde{J} \\
\tilde{z}\end{array}$ & 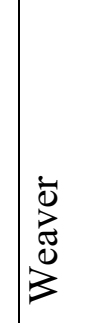 \\
\hline & 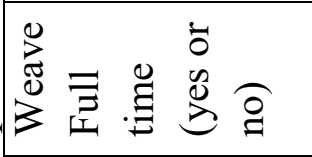 & $\stackrel{\infty}{\nearrow}$ & 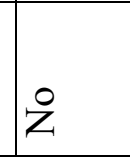 & $\check{z}$ & 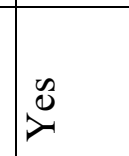 & 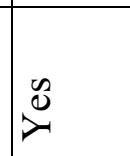 & $x^{\infty}$ & ż & $\not ̊$ \\
\hline & 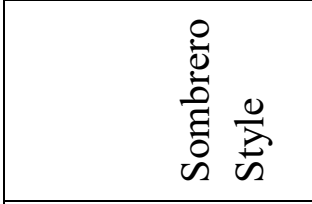 & "ُ & 这 & 这 & 这 & 爱 & 迹 & 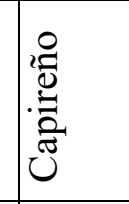 & 造 \\
\hline & 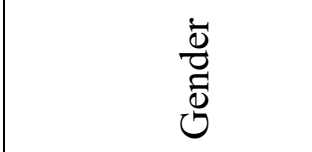 & $\Sigma$ & $\Sigma$ & $\Sigma$ & $\Sigma$ & $\Sigma$ & $\Sigma$ & $\Sigma$ & II \\
\hline & 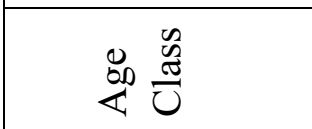 & 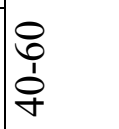 & 章 & 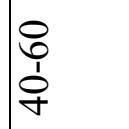 & 章 & 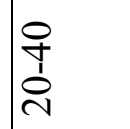 & 章 & 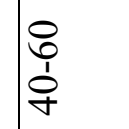 & 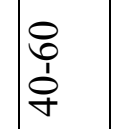 \\
\hline & 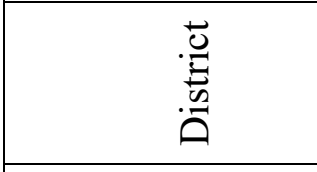 & 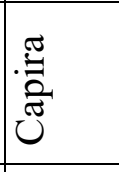 & 离 & Uี & 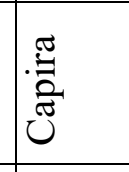 & Uू. & Uึ. & 舀 & Uू. \\
\hline & $\begin{array}{l}\text { 兽 } \\
\text { 音 } \\
\text { Oे }\end{array}$ & 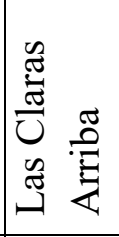 & 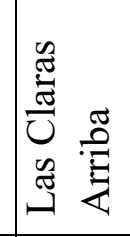 & 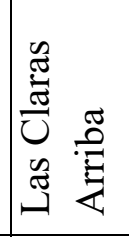 & 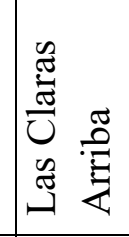 & 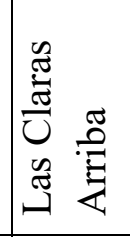 & 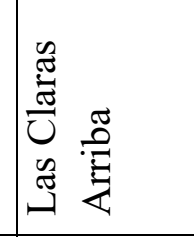 & 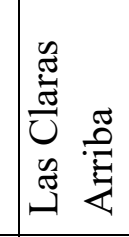 & 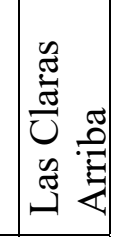 \\
\hline & $\underbrace{0}_{7}$ & - & $\mathrm{a}$ & $m$ & | & in & 10 & I & $\infty$ \\
\hline
\end{tabular}




\begin{tabular}{|c|c|c|c|c|c|c|c|c|c|}
\hline 0 & $\simeq$ & 0 & . & $\simeq$ & i & I & $\stackrel{\infty}{+}$ & $\stackrel{\infty}{+}$ & i \\
\hline : & . & . & . & 8 & 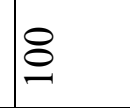 & 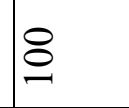 & $\stackrel{\beth}{\beth}$ & $\propto$ & $\propto$ \\
\hline 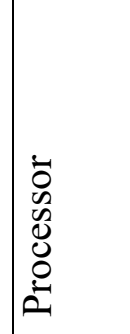 & 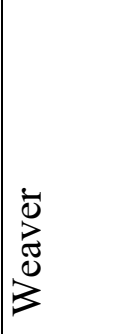 & 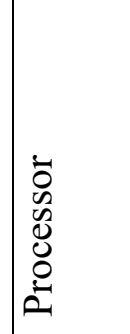 & 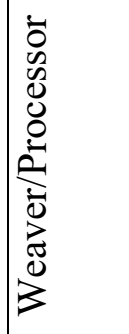 & $\begin{array}{l}\overrightarrow{\bar{D}} \\
\vec{E} \\
3\end{array}$ & 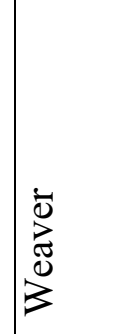 & 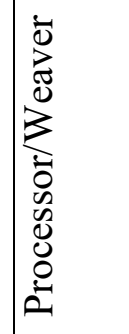 & 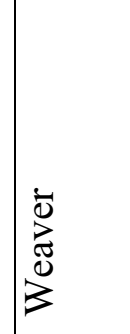 & 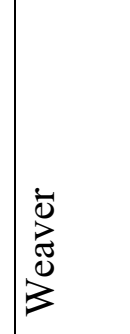 & 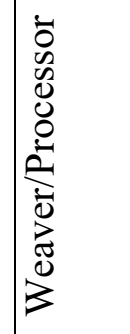 \\
\hline 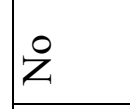 & z & 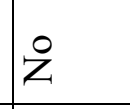 & $\grave{z}$ & 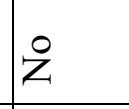 & $\stackrel{\infty}{\infty}$ & $\stackrel{\infty}{\infty}$ & 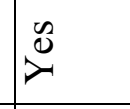 & $\underbrace{\infty}_{\nu}$ & $\stackrel{\infty}{\infty}$ \\
\hline 1 & 离 & . & 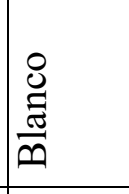 & 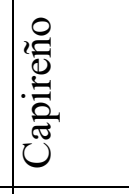 & 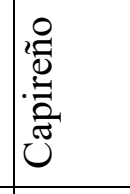 & 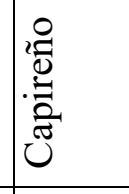 & 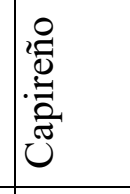 & 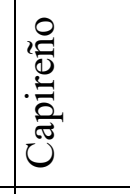 & 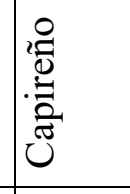 \\
\hline$\Sigma$ & $\Sigma$ & $\Sigma$ & $\Sigma$ & $\Sigma$ & $\Sigma$ & $\Sigma$ & $\Sigma$ & $\Sigma$ & $\Sigma$ \\
\hline $\begin{array}{l}0 \\
0 \\
0 \\
+ \\
\end{array}$ & $\begin{array}{l}8 \\
1 \\
1 \\
\\
\end{array}$ & 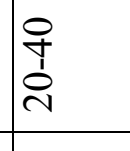 & $\begin{array}{l}0 \\
0 \\
1 \\
0 \\
0 \\
\end{array}$ & 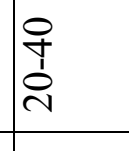 & $\begin{array}{l}8 \\
0 \\
\text { o } \\
\end{array}$ & $\begin{array}{l}8 \\
0 \\
1 \\
\end{array}$ & 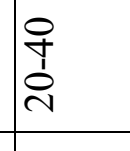 & $\begin{array}{l}8 \\
\vdots \\
\dot{9}\end{array}$ & $\begin{array}{l}\text { qu } \\
\text { ¿े } \\
\text {. }\end{array}$ \\
\hline 爫 & 苟 & 恕 & Uू. & 恕 & 乑 & שֶ & 㸓 & 繶 & 繶 \\
\hline 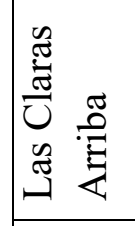 & 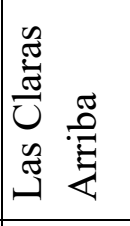 & 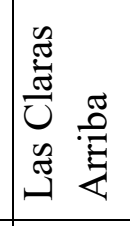 & 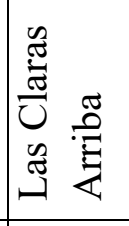 & 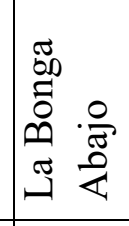 & 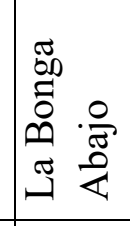 & 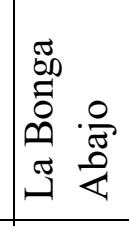 & 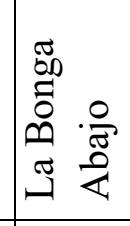 & 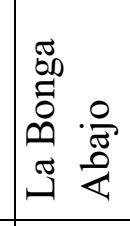 & 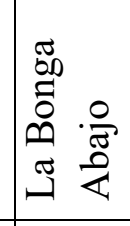 \\
\hline$a$ & 잉 & $=$ & $\vec{N}$ & $\stackrel{\circ}{\circ}$ & $=$ & $\infty$ & 2 & సิ & $\underset{\sim}{\infty}$ \\
\hline
\end{tabular}




\begin{tabular}{|c|c|}
\hline$\stackrel{\Xi}{\sim}$ & , \\
\hline 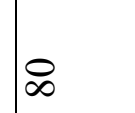 & 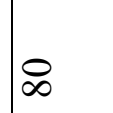 \\
\hline $\begin{array}{l}\bar{D} \\
\vec{D}^{0} \\
\sum^{2}\end{array}$ & 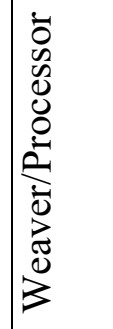 \\
\hline$\stackrel{0}{2}$ & $\stackrel{\circ}{z}$ \\
\hline 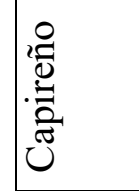 & 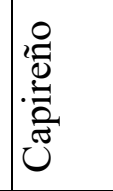 \\
\hline$\Sigma$ & $\Sigma$ \\
\hline $\begin{array}{l}8 \\
0 \\
1 \\
\\
+\end{array}$ & $\begin{array}{l}8 \\
\text { i } \\
\text { o } \\
\end{array}$ \\
\hline 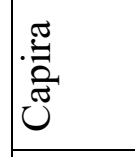 & Uू: \\
\hline 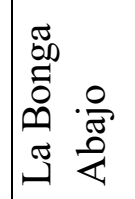 & 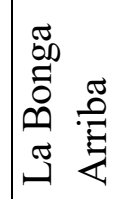 \\
\hline$\tilde{m}$ & $\stackrel{m}{m}$ \\
\hline
\end{tabular}




\section{APPENDIX A}

\section{Documentation that Figure 1 map is in the public domain}

All the maps are protected by copyright.

They are free for any use, even commercial, in the following conditions:

- The exact URL where the original map comes from must be mentioned

- The number of used maps is limited to 10 for a publication (Web, DVD, book...)

- The number of used maps is unlimited with BeGraphic GIS use.

For any additional details or particular asks, please contact us: webmaster@d-maps.com 


\section{APPENDIX B \\ Approval for Conducting Research in the Republic of Panama}

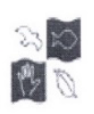

Ministerio de Ambiente

No.

R.U.C.: 8-NT-1-15033 D.V.: 88

38746

Dirección de Administración y Finanzas

Recibo de Cobro

Información General

Hemos Recibido De

SAMUEL CLAIR

Fecha del Recibo

$29 / 1 / 2016$

Administración Regional Oficina Central

Guia /P. Aprov

Agencia / Parque

Ventanilla Tesoreria

Tipo de Cliente

Contado

Efectivo / Cheque

No. de Cheque

La Suma De

Efectivo
TREINTA BALBOAS CON 00/100

B/ 30.00

Detalle de las Actividades

\begin{tabular}{|c|c|c|c|c|c|}
\hline Cantidad & Unidad & Cód. Act. & Actividad & Precio Unitario & Precio Total \\
\hline 1 & & 2.5 .1 & Permisos Cientificos & B/. 30.00 & B/. 30.00 \\
\hline
\end{tabular}

Observaciones

PAGO DE PERMISO CIENTIFICO 3-2016
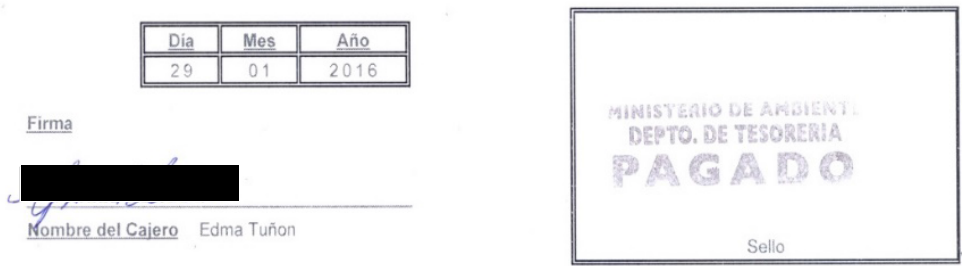

Figure 28. Proof of Payment for Scientific Permit from Ministry of Environment 


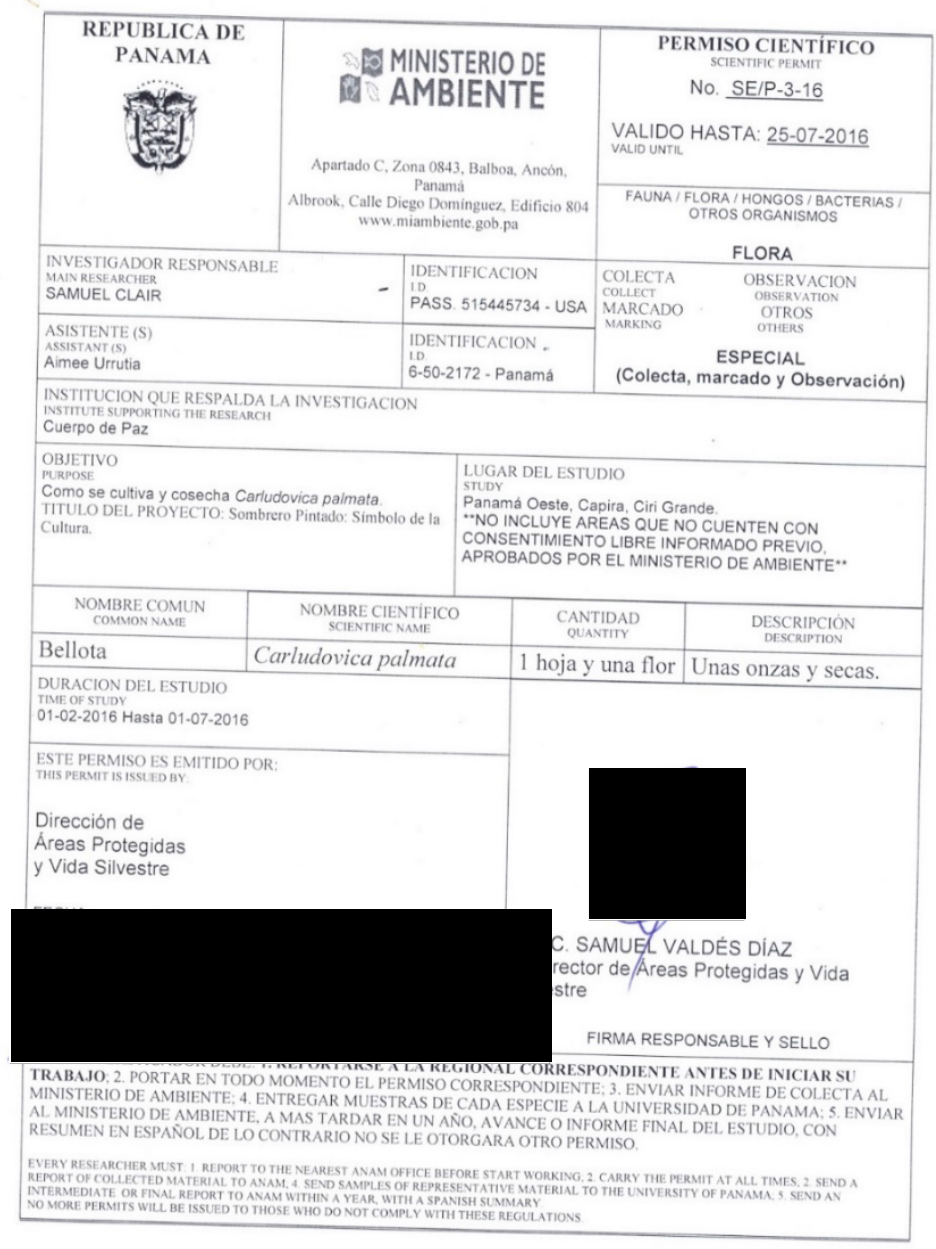

Figure 29. Scientific Permit from Ministry of

Environment 
Dear Country Director,

Current memorandums of cooperation signed with national universities participating in the Peace Corps Master's International (MI) program require that MI Peace Corps Volunteers (PCV) receive approval from post staff to conduct an academic project while serving. Academic projects may range from studies directly related to the student's primary Peace Corps assignment, to topics developed from secondary projects, or even research conducted during a student's own personal time. MI PCVs understand that they might have to adapt their overseas academic requirements to the specifics of their Peace Corps assignment.

We encourage you and your staff to become familiar with the MI PCV's area of study by meeting with the Volunteer and discussing the nature and objectives of his or her graduate assignment. By opening the avenues of communication between the MI PCV and your staff, we hope to minimize any misunderstandings that may arise and encourage the mutual sharing of information that may be of benefit to the post, the host country, and the MI PCV.

Research projects that involve human subjects must be screened through a university's Institutional Review Board and follow federal human subject research guidelines to ensure that the safety and privacy of host country nationals are protected. Universities also monitor the research project for academic quality and appropriateness.

The Peace Corps staff's responsibility is to ensure that a MI PCV's project does not interfere with his or her assignment responsibilities and that safety, medical, and security concerns are not compromised.

For our records, the MI program would appreciate your signature at the bottom of this letter acknowledging your approval for the MI PCV to conduct his or her academic project. Please keep a copy of this letter for your records, make a copy for the MI program, and return the signed original letter and a copy to the MI PCV.

Should you have any questions regarding the Peace Corps MI program, please feel free to contact mastersinternational@peacecorps.gov. Thank you for your assistance and cooperation.

Sincerely,

Master's International Staff

By signing below, I give my permission for Samuel Clair

to work on his/her MI academic project. This proiect must not interfere with hic/her nrimar

responsibilities as a Peac

Signature of Approval:

Please returned a signed

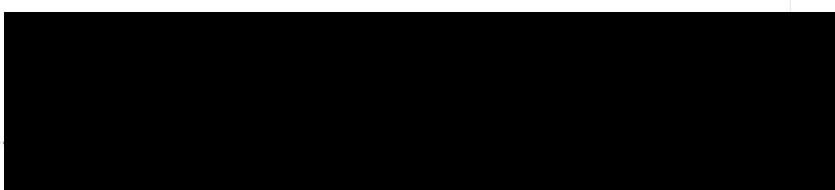

Figure 30. Approval from Peace Corps Country Director to Conduct Research While Serving in the Peace Corps in Panama. 


\section{APPENDIX C}

\section{Interview Questions}

Palm Ecology Questions

1. Where do you get your fiber?

2. Where does the seller live?

3. Who owns the land where fiber is grown?

4. Is the land titled?

5. Who processes your fiber?

6. Do you sell fiber?

7. How do you harvest and process the fiber?

8. How does this compare to in the past?

9. Are there special times of the year when you harvest?

10. Are there special times of the day when you harvest?

11. Can you get multiple harvests from one plant?

12. Do plants die after harvest?

13. How often do you harvest?

14. Do you ever have trouble finding fiber?

15. Why do you think you have trouble finding fiber?

16. Do you cultivate your plants?

17. Who planted your palms?

18. Which leaves do you harvest?

19. How many leaves are required to make a sombrero? 
20. Do you know how to process fiber?

21. Where do you find plants for fiber?

22. Has this location changed?

23. Why do you think this location has changed?

\section{Economic \& Market Questions}

1. How much do you pay for fiber?

2. How much did you pay in the past?

3. How much do you sell fiber for?

4. How much did you sell fiber for in the past?

5. Do you know of places where fiber is sold for more?

6. How do you decide the prices of fiber?

7. How much do you sell sombreros for?

8. How do sombrero prices compare to past prices?

9. What is the lowest you have sold a sombrero for? The highest?

10. Do you make different qualities of sombreros?

11. How does quality affect the prices of sombreros?

12. Is there a larger market for sombreros today than in the past?

13. How long does it take to make a sombrero?

14. How does sombrero quality affect the time it takes to make the sombrero?

15. What time of the day do you work on sombreros?

16. Do you work full time on sombreros? 
17. Besides sombreros, what other kind of work do you do?

18. How does your current work compare with past work?

19. Do you sell anything besides fiber or sombreros?

20. Do you wear a sombrero yourself?

21. How is sombrero price decided between weaver and client?

22. Do you sell directly to a client, to a middleman, or to both?

23. How do you find clients for sombreros/fiber?

24. Do you sell to family? Do you sell to people who are not family? Have there been any changes in the people you sell to?

25. How long does it take to process fiber?

26. Is there a reason why you do not process your own fiber?

27. Are prices negotiable for sombreros or fiber when selling at a market?

28. Are there different prices for sombreros and fiber within the community versus

\section{Additional Questions}

1. How long have you been weaving? Processing fiber?

2. At what age did you begin weaving? Processing fiber?

3. Did your parents weave?

4. Do your children weave?

5. How did you learn to weave?

6. Are you involved with any other crafts?

7. What materials do you use for dyes? 
8. What is the dye process? 